UNIVERSIDADE DE SÃO PAULO

FACULDADE DE EDUCAÇÃO

Tese de Doutoramento

\title{
POR UM SENTIDO PÚBLICO DA QUALIDADE NA EDUCAÇÃO
}

VANDRÉ GOMES DA SILVA

São Paulo

2008 


\section{VANDRÉ GOMES DA SILVA}

\section{POR UM SENTIDO PÚBLICO DA QUALIDADE NA EDUCAÇÃO}

Tese apresentada Faculdade de Educação da Universidade de São Paulo para a obtenção do título de Doutor em Educação.

Área de Concentração: Filosofia da Educação

Orientador: Prof. Dr. José Sérgio Fonseca de Carvalho

São Paulo

2008 
Autorizo a reprodução e divulgação total ou parcial deste trabalho, por qualquer meio convencional ou eletrônico, para fins de estudo e pesquisa, desde que citada a fonte.

Catalogação na Publicação

Serviço de Biblioteca e Documentação

Faculdade de Educação da Universidade de São Paulo

379

S586p
Silva, Vandré Gomes da

Por um sentido público da qualidade na educação / Vandré Gomes da Silva ; orientação José Sergio Fonseca de Carvalho. São Paulo : s.n., 2008.

120 p. : il.

Tese (Doutorado - Programa de Pós-Graduação em Educação.Área de Concentração : Filosofia da Educação) - - Faculdade de Educação da Universidade de São Paulo.

1. Qualidade da educação 2. Ensino - Qualidade 3. Ensino público 4. Escola pública 5. Educação para cidadania 6. Formação do indivíduo 7. Educação política I. Carvalho, José Sergio Fonseca de, orient. 
a Florence e Sylvio

a Roberta 


\section{AGRADECIMENTOS}

Ao CNPq, pela bolsa de estudos.

Aos colegas do Programa Melhoria da Educação no Município, pelo apoio dispensado.

Ao Cenpec, pelas experiências ricas e instrutivas.

Ao Heitor, pelo muito que ainda vamos aprender um com o outro.

A Maria Alice Peres, pela revisão cuidadosa e inteligente e pelos inestimáveis conselhos.

A Roberto Peres, pelas conversas bem humoradas e inspiradoras.

Aos meus primos Marcos, Roberta e Rodrigo pelo carinho e pelas questões inusitadas.

A Frances Azevedo, pelo interesse e pelas palavras de incentivo .

A Florence e Sylvio, pelo apoio constante, desde sempre.

A Wander e Valner, meus irmãos e amigos.

Aos companheiros de jogatina, Tatau, Erich, Zé, Wadson, Edu, Ricardo, , Fernando, pela boa sorte e descontração nos momentos mais necessários.

A amiga Neusa Borges (Pitita), pelo companheirismo e pelo exemplo como educadora.

Aos amigos queridos, em especial, Jorge Adilson, Adriana Biagione, Ricardo Mansano,

Diana Yuri, Paula Louzano, Laura Aquino, Janaina Maldonet, Juca Gil, Bebé e Sonia

Morozetti e Jackeline Gomes pela presença e apoio constantes.

A amiga Adriana Bauer, pelas conversas instigantes e pela parceria.

Aos integrantes do grupo de estudos Pensamento Contemporâneo e Educação, pelas discussões instigantes e valiosas e pelas diversas contribuições involuntárias.

A Marco Antonio Edreira, pela leitura preciosa e elegante, além da amizade.

Aos professores Bernardete Gatti e Romualdo Oliveira, pelas valiosas observações feitas no exame de qualificação.

À Confraria de Textos, na pessoa da amiga Helena Meidani, pela interlocução privilegiada.

A Roberta Peres, pelo amor incondicional, pela leitura inteligente de todas as versões deste trabalho desde o início, pela cumplicidade e por dar sentido à minha vida.

A José Sérgio Fonseca de Carvalho, pela orientação rigorosa e fraterna, pela amizade, pela postura profissional e por ser meu maior exemplo de agente público. 
A educação é o ponto em que decidimos se amamos o mundo o bastante para assumirmos a responsabilidade por ele e, com tal gesto, salvá-lo da ruína que seria inevitável não fosse a renovação e a vinda dos jovens. A educação é, também, onde decidimos se amamos nossas crianças o bastante para não expulsá-las de nosso mundo e abandoná-las a seus próprios recursos, e tampouco arrancar de suas mãos a oportunidade de empreender alguma coisa nova e imprevista para nós, preparando-as, em vez disso, com antecedência para a tarefa de renovar um mundo comum. Hannah Arendt 


\section{RESUMO}

SILVA, V. G. Por um sentido público da qualidade na educação. 2008. Tese (Doutorado) - Faculdade de Educação, Universidade de São Paulo, São Paulo, 2008.

A partir de uma análise conceitual de usos aparentemente consensuais do termo "qualidade" no campo da educação e apoiado sobretudo no conceito de público em Hannah Arendt, o presente trabalho discute a validade do que se denomina aqui narrativa instrumental da qualidade em educação. Essa narrativa se assenta na definição de qualidade restrita a determinados resultados obtidos pelos alunos, em termos de seu rendimento cognitivo, em avaliações de larga escala e à utilidade que porventura tenham esses resultados para a esfera social, conseqüência da indefinição dos limites entre as esferas pública e privada, típica da Modernidade.

Os pressupostos dessa narrativa utilitária se fundam em fins extrínsecos à própria educação escolar, relegando-a à condição de um simples meio para a satisfação de necessidades antes criadas por uma sociedade de consumo do que legitimamente estabelecidas por uma discussão de caráter eminentemente público e político. É como se o valor da escola pudesse ser estimado pela riqueza ou pelo status social que proporciona aos indivíduos ou pelo desenvolvimento econômico que pode acarretar. Nesses termos, a formação escolar se vê reduzida a atender a interesses socialmente valorizados, supostamente capazes de viabilizar as condições para se obterem mais e melhores resultados, alimentando um fluxo sem sentido.

A essa visão utilitária, opõe-se a vocação da educação escolar pública, que, reconhece a natalidade e a iniciação no mundo humano como seu fundamento e assume a responsabilidade por esse mundo sob a forma da autoridade a partir de uma herança pública e comum. Nessa perspectiva, a escola tem uma dupla responsabilidade: a preservação das tradições de conhecimento e formas de vida de um mundo preexistente - do qual os recémchegados vão se apropriando - e a possibilidade de agir sobre esse mundo, renovando-o.

Palavras-chave: qualidade de ensino, qualidade da educação, esfera pública, escola pública, formação escolar 


\begin{abstract}
SILVA, V. G. For a public sense of quality education. 2008. Thesis (Doctoral) - Faculdade de Educação, Universidade de São Paulo, São Paulo, 2008.

From a conceptual analysis of apparently consensual use of the word "quality" in the field of education and especially supported by the concept of public in Hannah Arendt, this work discusses the validity of what is called here instrumental narrative in quality education. This narrative is based on the definition of quality restricted to certain results obtained by the students in terms of their cognitive performance in large-scale evaluations and the usefulness that might have these results for the social sphere, a consequence of the lack of boundaries between public and private spheres, typical of Modernity.

The assumptions of such narrative are based on utilitarian purposes extrinsic to the school education, relegating it to the condition for a simple means to the satisfaction of needs before created by a society of consumption than legitimately established by a discussion of highly public and political character. It is as if the value of the school could be estimated by wealth or social status that gives individuals or the economic development that may entail.

Accordingly, the school can be seen reduced to meet the interests socially valued, supposedly capable of enabling conditions for obtaining more and better results, feeding a stream senseless.

That utilitarian view, is opposed to the vocation of public school education, which recognizes the birth and initiation in the human world as its basis and take over this world in the form of authority from a public and common heritage. Accordingly, the school has a dual responsibility: preserving the traditions of knowledge and ways of life of an existing world which the newcomers will be appropriating - and the ability to act on this world, renewing it.
\end{abstract}

Key words:, quality education, quality instruction, public sphere, public school, schooling 
FOLHA DE APROVAÇÃO

Vandré Gomes da Silva

Por um sentido público da qualidade na educação

Tese apresentada à Faculdade de Educação da Universidade de São Paulo para a obtenção do título de Doutor em Educação.

Área de Concentração: Filosofia da Educação

Aprovado em:

Banca Examinadora

Prof. Dr.

Insituição: Assinatura:

Prof. Dr.

Insituição: Assinatura:

Prof. Dr.

Insituição: Assinatura:

Prof. Dr.

Insituição: Assinatura:

Prof. Dr.

Insituição: Assinatura: 


\section{SUMÁRIO}

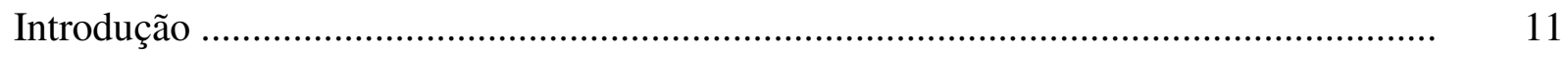

1. Uma perspectiva de análise da qualidade em educação .............................................. 15

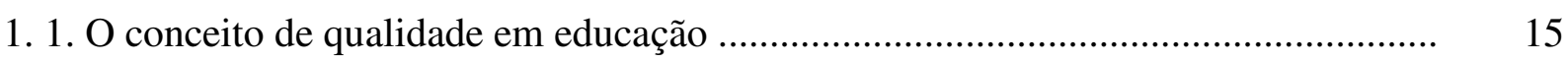

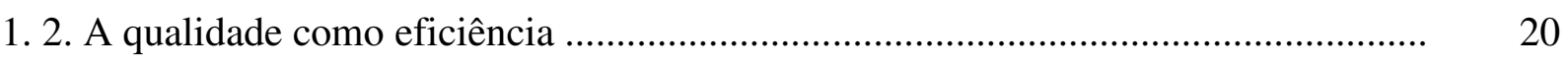

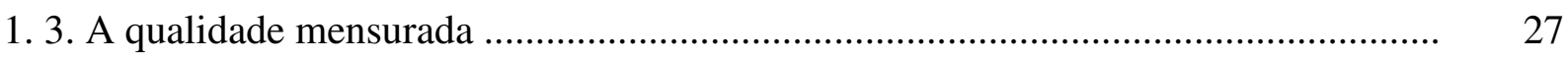

1. 4. A narrativa instrumental da qualidade em educação ............................................ 34

2. Esfera pública e a perspectiva instrumental da qualidade ......................................... 44

2.1. O publico e o privado em sua origem …............................................................. 45

2.2. O esvaziamento da esfera pública ...................................................................... 52

2.3. A imagem de excelência da escola particular e o estigma da escola pública ............ 63

3. A qualidade inestimável: educação como formação pública ......................................... 78

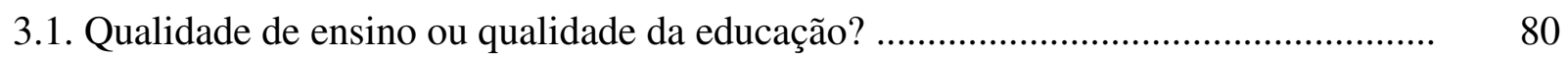

3.2. Fins extrínsecos à educação e a vocação escolar ........................................................ 88

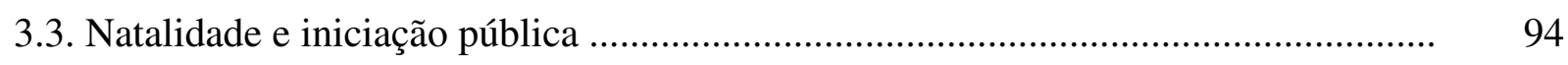

3.4. Qualidade da educação e esfera pública: contornos políticos da formação escolar ..... 100

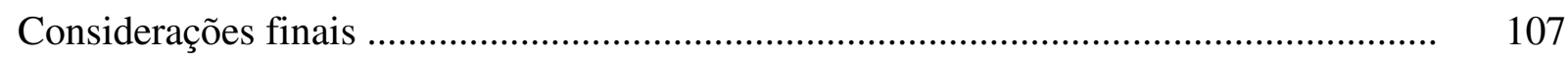

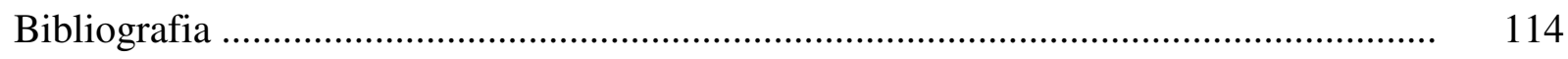




\section{INTRODUÇÃO}

Dificilmente se encontrará hoje alguém que se oponha a qualquer esforço para melhorar a "qualidade da escola pública". Considerando muitas das notícias e análises sobre o assunto, parece-nos que a noção do que seja qualidade em educação já está decidida, bastando alcançá-la ou, em certos casos, atestar sua "inegável” presença ou ausência. Aliás, a preocupação com essa qualidade é corroborada pela própria Constituição Federal, que estabelece, em seu Artigo 206, inciso VII, a "garantia de padrão de qualidade" como um dos princípios em que se assenta a educação escolar no Brasil. De fato, o termo em questão tem sido sobejamente utilizado nos discursos educacionais contemporâneos, o que lhe confere lugar de destaque nas discussões sobre educação e inegavelmente um ar de auto-suficiência explicativa.

Num primeiro momento, pode parecer desnecessário analisar e refletir acerca do conceito de qualidade aplicado à escola pública, pois há duas convicções que costumam nortear o que se tem dito a respeito no Brasil. A primeira "verdade" amplamente aceita é a de que a escola pública de hoje é ruim, tomando como parâmetro de uma boa escola aquela que era oferecida "antigamente". A segunda se afigura como a urgente necessidade de a escola pública conquistar a tão almejada "boa qualidade", o que quer que isso signifique. Mas a questão que não tem sido suficientemente discutida é: de que qualidade se está falando?

Não é por acaso que a própria veiculação do termo se dê, em muitos casos, por meio de simples slogans, por instituições e agentes tanto privados como públicos. Trata-se de um evidente esforço para atestar uma suposta qualidade presente nos trabalhos que prestam ou, ao menos, para deixar claro que essa é a principal meta a atingir. Nas palavras de Israel Schaffler:

\footnotetext{
Em educação, os slogans proporcionam símbolos que unificam idéias e atitudes chaves dos movimentos educacionais. Exprimem e promovem, ao mesmo tempo, a comunidade de espírito, atraindo novos aderentes e fornecendo confiança e firmeza aos veteranos. [...] Com o decorrer do tempo, entretanto, muitas vezes os slogans passam a progressivamente a ser interpretados de maneira mais literal, tanto pelos aderentes como pelos críticos dos movimentos que eles representam. Passa-se a considerá-los cada vez mais como argumentos ou doutrinas literais, e não mais simplesmente como símbolos unificantes (Scheffler, 1974, p. 46-47).
}

Slogans que lançam mão do termo "qualidade" são muito comuns e revelam um forte indício de seu uso de forma sumária, discutível e muitas vezes vaga. Normalmente são 
"repetidos com veemência ou de maneira tranqüilizadora", e não de modo a serem "gravemente meditados", isto é, não se pode tomá-los como uma tentativa séria de explicação dos termos que veiculam e tampouco têm a intenção de facilitar o discurso (Sheffler, 1974, p. 46). O próprio contexto em que os slogans são veiculados e eventualmente discutidos se converte em fator determinante para sua análise.

No Brasil, chamam atenção certos tipos de enunciado bastante veiculados e, na mesma medida, arraigados - "caiu a qualidade do ensino", "a escola pública não tem qualidade", "a qualidade da escola privada é muito superior à da escola pública” etc. Não raro, essas frases de efeito denotam um aparente consenso, embora não sejam acompanhadas de maior reflexão acerca de seus pressupostos ou de outras dimensões do conceito de qualidade, em especial quando se refere à escola pública. Os pressupostos subjacentes a esses usos podem revelar questões fundamentais, principalmente quando se interpreta literalmente essa "queda da qualidade de ensino", a ponto de a principal característica da escola pública ser a "falta de qualidade". Que pressupostos subjazem a essas afirmações tão comuns?

Ainda que o tema da "qualidade de ensino" e correlatos se apresentem hoje de forma bastante enfática e constante, o debate em torno do conceito não é recente no Brasil. Talvez o ponto mais candente dessa discussão tenha se dado a partir do final da década de 1960, quando a qualidade estava intimamente ligada ao acesso à escola pública, a partir da expansão das vagas numa proporção jamais vista no país, iniciada no Estado de São Paulo.

O crescimento da rede de escolas do então ensino de $1^{\circ} \mathrm{Grau}$ em São Paulo teve início em 1967; antes, esse crescimento era apenas vegetativo e jamais teria alcançado efetivamente a população de renda mais baixa. Até então, o antigo ginásio - que compreendia os atuais $6^{\circ}$ a $9^{\circ}$ anos - selecionava os alunos por meio de exames de admissão, em que passava apenas uma elite de candidatos egressos da escola primária (Azanha, 1995, p. 12).

Com o ensino primário "praticamente universalizado", o ginásio funcionava como verdadeiro funil, restringindo à maioria dos alunos o prosseguimento nos estudos e o direito à educação pública - o que significava, para as classes populares, a negação do direito a qualquer educação escolar após a conclusão do primário. As medidas políticas tomadas em nome dessa democratização do acesso visaram à unificação dos exames de admissão das escolas paulistas, tornando-os menos rigorosos. Sob a responsabilidade das próprias unidades escolares, esse exame era um instrumento bastante eficaz de seleção e discriminação dos alunos. 
Essa decisão política ensejou uma “intensiva ocupação do espaço escolar” público, o que mudou radicalmente a realidade escolar e, conseqüentemente, as circunstâncias do trabalho docente. Desse modo, "grande parcela do professorado" opôs resistência à expansão de vagas, encontrando "ampla ressonância no pensamento pedagógico da época"1 (Azanha, 1987, p. 32).

Nesses termos, a concepção de que a "escola pública de qualidade é a escola de antigamente" ou de que houve uma "queda na qualidade de ensino" implica a convicção de que outrora a qualidade existente era boa e, por algum motivo, se deteriorou. Trata-se de invocar, mesmo inconscientemente, as características e as condições daquela escola seletiva e restrita de outros tempos, ainda que mantida pelo Estado. Seu restabelecimento - apenas hipotético, evidentemente - implicaria retomar determinados valores, práticas e circunstâncias específicas que constituíram. Essa escola pública:

[...] já não existe na situação do ensino comum da rede de escolas públicas no presente. A escola pública mudou com sua expansão quantitativa: são outros os seus agentes - alunos, professores, famílias - e sua circunstância, e essa mudança reformulou suas funções sociais e suas condições de funcionamento.

A crise do funcionamento da escola pública na atualidade, os graves problemas de rendimento do sistema de ensino, da escola, de seus educadores e de seus alunos, não surgem como produtos da degeneração de uma excelente escola que teria existido no passado. São problemas que se definem e devem ser equacionados no âmbito de uma realidade escolar nova que ainda não conseguiu se construir (Beisiegel, 2007, p. 143 - grifo do original).

Além de anacrônica, a qualidade de ensino formulada a partir da "recuperação da presumida excelente qualidade da escola pública do passado", como nos alerta Beisiegel, põe em xeque uma condição fundamental da escolarização de toda uma população: uma formação escolar pública, porque extensiva e destinada a todos.

\footnotetext{
1 Exemplo eloqüente dessa resistência à expansão de vagas é a relação dos ginásios vocacionais públicos do Estado de São Paulo (mantidos entre 1962 e 1970) com a política adotada pela Secretaria de Educação de São Paulo, implantada a partir de 1967. Adeptos de uma concepção pedagógica alegadamente "democrática", os colégios vocacionais se notabilizaram por uma proposta tida como inovadora. Contudo, a "recusa veemente" desses colégios em participar dos exames unificados e facilitados de admissão ao antigo ginásio - laçando mão da ampla autonomia didática, administrativa e financeira de que dispunham - evidenciou uma perspectiva inusitada da democratização do ensino em espaço público, pois, "não obstante a preocupação com o povo, os ginásios vocacionais conceberam a democratização do ensino como fundada numa prática pedagógica infelizmente reservada a poucos pelo alto custo que importava" (Azanha, 1987, p. 36). A autonomia escolar, tão comumente associada à gestão democrática, possibilitou aos ginásios vocacionais lançarem mão de procedimentos contrários à vida democrática, insistindo na seleção - e, portanto, na exclusão - dos alunos.
} 
Para além do significado literal dessas palavras, ao se afirmar abstratamente a "queda" ou a "ausência" da qualidade da escola pública, está se veiculando um sentido prático e norteador vinculado ao conceito. Trata-se de uma "intenção programática" (Sheffler, 1974) que estigmatiza e desvaloriza a escola pública na mesma proporção em que enaltece cada vez mais a iniciativa privada no campo educacional e uma insuspeita imagem de excelente qualidade associada à escola particular. É como se qualidade de toda e qualquer escola estatal ou privada - independesse de seu caráter e interesse públicos.

Assim, partimos de uma análise conceitual do termo "qualidade", em especial de seus usos preponderantes na atualidade não só como uma explicitação dos significados subjacentes, mas também para apreender o sentido mesmo desses discursos. Contudo, como ressalva Hannah Arendt (1995, p. 113), o sentido não "pode ser nunca o desígnio da ação e que no entanto surgirá inevitavelmente das realizações humanas após a própria ação ter chegado a um fim".

Não se trata, portanto, de uma investigação que discute tipos de gestão ou métodos de ensino supostamente mais eficazes, capazes de "melhorar a qualidade" da educação, mas antes investigar e discutir o mérito de uma questão fundamental e preliminar: qual é a qualidade que se quer para a escola pública?

Reconhecemos que esta análise é ambiciosa, tanto por seu tema como por sua abrangência, mas nossa intenção é mais modesta. Pretende apenas incluir na discussão em torno do conceito de qualidade em educação no Brasil algo além do que se está fazendo e propondo - fundamentalmente, aquilo em que nem vagamente se toca nesse debate. Na feliz formulação de Hannah Arendt (2005): “Certamente há mais aqui do que a enigmática questão de saber por que Joãzinho não sabe ler". 


\section{1 - UMA PERSPECTIVA DE ANÁLISE DA QUALIDADE EM EDUCAÇÃO}

\section{$1.1 O$ conceito de qualidade em educação}

Num tema como o da qualidade em educação, parece haver um razoável consenso entre as diversas vozes interessadas: o de que estamos imersos numa crise educacional. Os resultados escolares, seus meios de aferição e a discussão que suscitam parecem ser seus indícios mais visíveis, à medida que se identificam diminutas ilhas consideradas "escolas de qualidade", em meio a um mar de outras unidades, notadamente públicas, marcadas por desempenhos classificados como sofríveis e muito aquém do esperado. Há certamente outros indícios, menos objetivos, desse estado de coisas, muitos deles presentes no discurso de boa parte dos professores - por exemplo, as queixas a respeito de uma irremediável "falta de disciplina" dos alunos, dos baixos salários, das condições de trabalho insatisfatórias e da violência dentro das escolas. Essas e muitas outras impressões, cotidianamente divulgadas, parecem confirmar e estabelecer a evidência da má qualidade da educação como uma conclusão necessária da inegável crise educacional que vivemos.

Na busca de alternativas para esse estado crítico da realidade educacional, os esforços de investigação ganham destaque, procurando detectar suas causas e, conseqüentemente, apontar meios e formas de superá-lo. Mas esse caminho - previamente estipulado e praticamente imposto pela tão propalada "queda da qualidade" - esbarra num pressuposto precioso e indispensável: numa pesquisa, as perguntas são tão ou mais importantes do que as respostas que se obtenham e, às vezes, seu mérito e sua importância residem tão-somente nas questões que a norteiam.

De fato, a discussão e a análise do tema em questão implicam aceitar um desafio repleto de armadilhas. Talvez a primeira delas seja a de ver no conceito de qualidade um objeto de pesquisa claramente definido, passível de descrição ou, o que é mais comum, da detecção inequívoca de sua falta. Como afirma Bernard Charlot, não é fácil para o pesquisador questionar um problema tal como ele se lhe apresenta, desconstruir e reconstruir esse objeto, menos ainda quando o “objeto aparece amiúde evidente para o próprio pesquisador, o qual se vê preso, como pessoa particular, aos desafios ideológicos que conferem uma aparente consistência ao objeto" (2000, p. 15).

Uma precaução importante pode ser a de desconfiar de formulações, quase inevitáveis, como “o que é educação de qualidade?" ou "a queda na qualidade de ensino se deve a...”. 
Nesses termos, questões como essas podem induzir à falsa idéia de que há uma qualidade essencial ou verdadeira em educação, a qual só nos restaria descobrir.

O uso de expressões como "qualidade da educação" e outras correlatas nada mais é do que um recurso lingüístico, ou um significante ${ }^{2}$, que atribui valor a alguma coisa, conferindolhe distinção em função de uma ou mais características suas consideradas superiores ou de excelência. Por exemplo, uma determinada escola pode ter uma série de características facilmente verificáveis como dispor de oito salas de aula, uma biblioteca, dois coordenadores pedagógicos, um diretor formado em Pedagogia e um corpo docente com formação em nível superior. Uma possível classificação dessa escola como "de qualidade” poderia considerar como um fator de distinção a presença de professores com curso superior, mas essa mesma informação pode suscitar desconfiança e até se converter em fator de valoração negativa se esses professores forem considerados "mal formados" por terem estudado em faculdades ou universidades de "má qualidade". Ainda que a escola em questão seja factualmente a mesma, não seria de estranhar que a percepção sobre sua qualidade fosse radicalmente diferente.

Em seu uso corrente, o termo "qualidade" caracteriza um determinado estado de coisas num sentido positivo. Ao afirmar que "um produto é de qualidade" ou que "uma escola é de qualidade", atribuímos-lhes condição ou situação desejável. Por oposição, algo é considerado de má qualidade na medida em que se distancia daquilo que é esperado ou desejado. Este breve arrazoado nos dá uma idéia do contorno do uso do termo, mas não nos informa sobre aquilo a que se refere, pois a definição e o significado da qualidade de qualquer coisa varia em duas direções distintas e concomitantes: de objeto para objeto e de acordo com o contexto histórico onde ele é, por assim dizer, qualificado.

Podemos colher um exemplo disso na visão de parte da população do que seria uma escola de qualidade há 40 ou 50 anos no Brasil. Uma escola "forte", "exigente", preocupada em ensinar aos alunos determinados conteúdos de forma rigorosa e invariável, reprovando implacavelmente aqueles considerados "inaptos" ou "pouco esforçados". Não seria exagero afirmar que, quanto mais uma escola reprovava, tanto mais era considerada de qualidade. É claro que essa concepção convivia com outras, não raro divergentes e contando com mais ou menos adesões, conforme seus pressupostos e o lugar de onde eram veiculadas e discutidas. Hoje, ainda é freqüente encontrarmos a velha percepção de que a boa escola era a "escola pública de antigamente", convivendo com inúmeras outras visões do conceito. Ou seja, é

\footnotetext{
${ }^{2} \mathrm{O}$ conceito de qualidade em educação assumiria um papel de "significante, e não um significado", conferindolhe um traço peculiar que é o de "adquirir muitos significados" certificados na literatura educacional (Risopatron, 1991, p. 15).
} 
comum haver diferentes concepções de qualidade em relação a um mesmo objeto convivendo num mesmo tempo histórico ou um mesmo parâmetro de qualidade aplicado anacronicamente a diferentes contextos históricos.

Não é fortuito que a produção teórica dedicada à análise do conceito de qualidade em educação - em especial, nas duas últimas décadas, por iniciativa de organismos internacionais - revele a perspectiva comum de um "um campo altamente problemático de definição e intervenção" (Risopatron, 1991). Essa percepção do problema parece repousar na inegável "existência de muitas definições de qualidade em educação, atestando a complexa e multifacetada natureza do conceito" (Unicef, 2002), além da "confusão conceitual” expressa na literatura educacional a partir do "uso abundante de redundâncias e tautologias" em torno da expressão (Adams, 1990).

Se o uso da expressão "qualidade em educação" pode algumas vezes não fazer nada além de esvaziar o conceito de um significado claramente identificável, outras vezes parece confirmar a impressão de que a observação de um determinado objeto é praticamente inseparável da interpretação que se faz dele (Hanson, 1975). Basta imaginar quão diferentes podem ser as visões da qualidade de uma mesma escola pública por parte de uma família de classe média que recorre a ela por seus rendimentos já não permitirem o pagamento das mensalidades de uma escola particular e de uma outra, mais pobre, cujos pais nem sequer concluíram o ensino fundamental.

Portanto, dizer "essa é uma escola de qualidade" não significa ter descoberto ou comprovado suas características reais, mas interpretá-las a partir de certas condições históricas, territoriais, culturais, de classe ou grupo social. Na medida em que o conceito de qualidade é socialmente construído, importa aqui o modo como se estabelece a relação entre os sujeitos e aquilo que é qualificado. Não se trata uma propriedade a ser identificada e apreendida na realidade, mas de um ajuizamento de valor a partir da concepção que se tenha de qualidade.

Assim, a qualidade em educação e suas diversas expressões não constituem um objeto de investigação empírica, mas algo semelhante ao que Charlot (2000, p. 14) denomina "atrativos ideológicos", na análise que faz da expressão "fracasso escolar". As percepções tão comuns que atestam um evidente "fracasso escolar" ou a "queda na qualidade de ensino" assumem o papel de "categorias imediatas de percepção da realidade social". Sua condição de objetos de discurso adquire enorme peso social e midiático, uma vez que "são portadores de múltiplos desafios profissionais, identitários, econômicos, sociopolíticos" (Charlot, 2000, p. 14). 
Nessas condições, é razoável não tomar a noção de qualidade em educação como autoexplicativa, porque sobre ela repousam muitos e diversos significados e a possibilidade da criação de outros mais. Mas o que ocorre é justamente o contrário, como se vê pela reiterada utilização da expressão "qualidade" em slogans educacionais, tanto na rede pública como notadamente na rede privada de ensino.

Uma investigação que se volte a um conceito como esse enfrentará de antemão um duplo desafio: ao mesmo tempo em que deve deixar claro o que entende por qualidade aplicada ao campo da educação, não deve perder de vista a polissemia da expressão e a inevitável ambigüidade que seu uso acarreta. A esse respeito, Beisiegel diz não haver:

[...] uma explicação exclusiva ou claramente superior a todas as demais para [as] expressões dos problemas da qualidade [...] [que têm] natureza e fundamentação muito diversas, definem critérios também bastante diversificados, atendem de modo parcial e desigual a diferentes aspectos dos fenômenos [...] examinados (2005, p. 8).

Não se pode negar que "qualidade em educação" pode significar muitas coisas, e tampouco ignorar que em muitos desses significados há coesão e adequação em função de pressupostos e interesses mais ou menos explícitos. Uma determinada concepção de qualidade parecerá inevitavelmente superior às outras, dependendo da aceitação e adesão a seus pressupostos, interesses e visão da educação escolar subjacentes. E seria estranho se fosse diferente. Entretanto, uma análise sob essas condições pode facilmente ceder à tentação de considerar de "maior qualidade" um modelo educacional ou um determinado tipo de escola a partir de critérios particulares a certos grupos ou segmentos sociais, isto é, orientados por interesses alheios à esfera pública.

Por outro lado, a busca de pontos comuns entre os diversos - e às vezes contraditórios - significados de qualidade pode ser um expediente bem intencionado, mas não exatamente profícuo ou abrangente, se deixar de abordar os pontos de discórdia e conflito, mais agudos e fundamentais, e seus condicionantes. Uma análise nesses termos tende facilmente a se deslocar de um âmbito político e ligado ao interesse público para uma discussão de caráter pretensamente técnico e restrito, comumente pautada pela definição dos meios, recursos e metodologias que favorecem uma determinada concepção de qualidade previamente estipulada. Dessa forma, a perspectiva de que cada idéia de qualidade pode compreender significados distintos em um campo de disputa - não tanto de fatos, mas de conceitos 
alternativos e não raro excludentes - perde importância ou nem sequer é mencionada ${ }^{3}$. Quando se toma apenas um de seus possíveis significados, é como se a qualidade fosse "neutra" e "universal" (Risopatron, 1995, p. 15).

Parece que precisamos adotar aqui alguns critérios comuns para a análise de diferentes concepções em jogo na abordagem do termo, e destacamos menos o caráter de substantivo da palavra "qualidade" do que sua inegável função de adjetivo, que confere algum significado à educação, seja ele qual for. Além de bastante tortuoso, seria enigmático apreender o que se quer dizer com "qualidade", sem abordar o que é de fato substantivo nesta discussão: o que se quer dizer com "educação". Nestes tempos em que cada vez mais prepondera uma visão menos plural e mais determinista do que a instituição escolar pode e deve fazer, é bastante interessante procurar entender o que se quer dizer com "qualidade" e, conseqüentemente, as eventuais concepções de educação subjacentes ao uso do termo.

Nesse sentido, segundo Hirst e Peters (1972), a perspectiva de uma análise conceitual pode favorecer a reflexão sobre o significado de conceitos presentes nos discursos pedagógicos ou que sejam de interesse do campo educacional - como é o caso de "qualidade" -, os contextos em que são veiculados e as condições de seus usos. Seu foco se volta para discussão não tanto de uma "realidade" em si, mas da forma ou formas de enxergá-la e suas eventuais consequiências. Como observa Carvalho (2001, p. 21), esse tipo de análise, de cunho filosófico, tem-se "mostrado um instrumento bastante interessante para o esclarecimento das tarefas educativas e mesmo para a coordenação, a justificativa e o estabelecimento de metas e valores que visam a conduzir as ações educativas no âmbito escolar".

Assim, analisar e discutir a qualidade em educação requer reflexão sobre seus significados usuais - ao menos os mais comuns -, a verificação de seus pressupostos e de suas pretensões e a força de sua veiculação; além disso, devem-se explicitar as contendas, as decisões e as escolhas, ao se lidar com eles. Ao mesmo tempo em que se consideram, por exemplo, as formas pelas quais se fala em qualidade em variados contextos, não se pode perder de vista que alguns valores e objetivos devem prevalecer sobre outros, justamente por se tratar de uma prática social pública realizada pela escola. Como destacam Hirst e Peters:

\footnotetext{
${ }^{3}$ Parece ser esse o caso do estudo do Unicef Definig Quality in Education, onde se afirma que: "No mapeamento da recente literatura de pesquisa relacionada à qualidade em educação, o Unicef parte de uma ampla perspectiva e demonstra em sua análise que os programas devem abarcar uma definição ampla que envolva alunos, conteúdos, processos, ambientes e resultados" (2000, p. 2), uma vez que "de qualquer forma, há hoje em dia um considerável consenso acerca das dimensões básicas da qualidade educacional” (2000, p. 4). Chama atenção aí o viés e o tipo de preocupação que orienta o estudo, embora isso de forma alguma o desqualifique ou diminua seu interesse em muitos dos temas que aborda.
} 
A análise conceptual ajuda-nos a fixar de maneira mais precisa o que está implícito em nossa consciência moral. Mas ela também nos permite afastarnos um pouco e refletir sobre o status da exigência à qual a palavra testemunha. Ela nos deixa livres para fazer a pergunta fundamental em ética, que é a de se essa exigência é justificada. Na nossa opinião, não vale muito a pena fazer análise conceptual, a menos que alguma questão filosófica se torne, desse modo, mais manuseável.

Portanto, a primeira coisa a dizer sobre o objetivo de se fazer análise conceptual é que se trata de uma preliminar necessária para responder a algumas outras perguntas filosóficas. Não podemos enfrentar uma questão ética sobre quaisquer boas razões para se punirem pessoas até que estejamos certos do que queremos dizer com "castigo". Em outras palavras, as questões de análise muitas vezes estão ligadas a questões de justificativa (Hirst; Peters, 1972, p. 20-21).

Sob essa perspectiva, podemos ver no potencial campo de disputa acerca do conceito de qualidade em educação um denominador comum em relação às diferentes concepções de educação e seus respectivos parâmetros de qualidade. Esse denominador é a própria configuração da educação escolar como uma prática de caráter público, cujo interesse, aqui, parece ser inversamente proporcional ao sentido preponderante que os discursos em torno da qualidade têm freqüentemente tomado.

\subsection{A qualidade como eficiência}

Por mais gritantes que sejam os problemas que afloram em meio a uma alegada "queda da qualidade de ensino" ou "da educação", sua percepção e causa parecem estar fortemente relacionadas ao significado que damos à educação e ao confronto em torno dos pressupostos e repercussões das concepções em jogo.

Supor que "qualidade em educação" seja um conceito tão independente e "evidente"4 que possa ser dissociado dos interesses e características de uma educação pública significa destituir a expressão de um significado interessante e pertinente à formação de um povo e à construção de sua cidadania.

Há de fato muitos critérios pelos quais se julga ou se caracteriza uma escola de qualidade que, muito embora sejam amplamente divulgados, não se vinculam imediata ou

\footnotetext{
${ }^{4}$ Essa auto-evidência teria sido recorrente na análise da literatura sobre a qualidade em educação feita no início dos anos 1990: "Se supõe evidente aquilo que se conhece por demais, como a luz do sol em relação aos objetos que vemos. Ao não abordar uma maior precisão do conceito de qualidade de educação, este continuará sendo evidente, com as consequiências que acarreta para a implementação de medidas de política educacional que tendem à sua melhora" (Risopatron, 1991, p. 44).
} 
talvez legitimamente à esfera pública. Para ilustrar alguns tipos de usos da expressão, bastante comuns atualmente, Beisiegel nos oferece um pequeno leque de possibilidades:

\begin{abstract}
Qualidade de ensino é matéria de grande complexidade e sua discussão envolve amplo elenco de questões. Em diferentes aspectos, alunos, professores, escolas e até mesmo sistemas de ensino têm sido examinados sob o ponto de vista dos respectivos desempenhos: apenas como exemplos, alguns alunos aprendem melhor ou mais rapidamente do que outros; alguns professores ensinam com mais eficiência; conhecem melhor suas disciplinas ou são mais bem aceitos pelos alunos; alguns conteúdos programáticos são mais avançados ou mais extensos do que outros; algumas escolas são mais procuradas, porque os alunos ou seus pais consideram-nas melhores do que outras; o ensino médio público seria menos eficiente do que o particular, etc. Muitas pesquisas, reflexões, propostas e até mesmo palpites sobre a educação escolar têm focalizado essas e outras questões que de alguma forma estão relacionadas com o que poderia ser entendido como qualidade de ensino (2005, p. 7 - grifos nossos).
\end{abstract}

A ampla gama de perspectivas cujo discurso lança mão da palavra "qualidade" pode ser um fator impeditivo de sua investigação, se tivermos a pretensão de um mapeamento exaustivo de seus significados. Entretanto, chama primeiramente a atenção, nesse rol de perspectivas, que em cada concepção ou entendimento da "qualidade de ensino" se priorizam determinados valores em detrimento de outros. Assim, um professor pode ser mais eficiente ou agradável, um aluno pode aprender com mais rapidez, uma disciplina pode ser mais avançada, algumas escolas podem ser mais desejadas e escolas particulares são comumente vistas como mais eficientes do que escolas públicas. Na medida em que veiculam valores, tais perspectivas implicam critérios comparativos, ao menos em duas perspectivas distintas. A primeira diz respeito à intensidade com que são percebidos, algo bastante comum em discursos que atestam, por exemplo, que uma escola "tem mais qualidade que outra". Por outro lado, comparações podem ser feitas por meio da exclusão de critérios valorativos considerados indesejáveis, como determinar que escolas de qualidade seriam apenas aquelas que "aprovam seus alunos nos vestibulares mais concorridos" ou então estipular que a qualidade em educação implicaria necessariamente "a adoção de uma gestão democrática". A identificação desses usos do conceito permite determinar o sentido dos valores ${ }^{5}$ atribuídos à

\footnotetext{
${ }^{5}$ Segundo Risopatron, essa é uma característica subjacente ao uso do conceito verificado na análise da literatura educacional: "A qualidade da educação é um valor e, como tal, é natural, ou seja, se nega o caráter histórico da atribuição de valor" (1991, p. 43). Mas identificar que o uso do conceito é valorativo não implica uma maior clareza ou necessidade de explicitação de qual seja seu caráter histórico ou de como é atribuído historicamente, o que, aliás, pode ser feito por quem analisa tais concepções. Criticar uma determinada definição de qualidade por não enxergar esse caráter é uma forma de perder de vista seu próprio traço valorativo, adotado em meio a uma série de variáveis e condições, históricas inclusive. Em qualquer perspectiva e quem quer que sejam seus autores
} 
educação que norteiam uma instituição escolar e em que medida são compatíveis com seu caráter público.

Outro aspecto importante destacado por Beisiegel é um traço valorativo comum entre muitos desses usos. Se, à primeira vista, percebemos diferentes significados de "qualidade", quando procuramos ordená-los e classificá-los, uma constante se revela. Não é aleatório que o uso do termo esteja circunscrito pelo viés do desempenho, seja de estudantes, professores, escolas ou sistemas de ensino. Nesses termos, é comum que se busque conjugar critérios como comparabilidade e resultado, por assim dizer, de um processo de escolarização, na medida em que "desempenho" designa a execução e o cumprimento de uma determinada tarefa ou função. Detectar, aferir ou deliberar se uma determinada função foi ou não bem desempenhada são típicos julgamentos distintivos feitos sob o rótulo da qualidade.

Certamente, não se trata de qualquer desempenho obtido pela educação escolar - que, assim, prescindiria de qualquer critério ou parâmetro -, mas dos desempenhos circunscritos a uma tendência predominante, em especial a partir do início dos anos 1990, apontada por Adams (1993) no mapeamento e na análise dos usos mais correntes do conceito em seu trabalho Defining Educational Quality. A ênfase na discussão e proposição de políticas de qualidade da educação estaria relacionada a condições, internas e externas, assim definidas:

Fatores contextuais ou externos incluíram a reação à ênfase da demanda educacional em termos de crescimento quantitativo. Tal ênfase, em geral, falhou ao não atingir as expectativas nacionais predominantes e resultou em muitos "desempregados escolarizados", em meio a mudanças de ordem econômica e tecnológica que demandaram um aumento no nível de habilidades e conhecimentos. O maior fator educacional interno relaciona-se à escola contemporânea e à pesquisa em salas de aula, criando um senso profissional mais otimista pela sugestão de que as escolas, independentemente de seu contexto socioeconômico, podem ser direcionadas para aumentar a aprendizagem (Adams, 1993, p. 3).

Aplicada ao caso brasileiro, a percepção de Adams talvez pareça algo exagerada pois, no Brasil, além das especificidades e do contexto educacional e social característicos, o enorme contingente de desempregados tem pouca escolarização. Todavia, mais do que sua eventual aplicabilidade a um determinado país ou tipo de escola, o autor chama atenção para a ênfase com que se tomam os resultados (outcomes) e produtos (outputs) escolares, assim como os custos e insumos necessários à ampliação ou manutenção da rede escolar (inputs) nas discussões e análises da qualidade em educação, pautadas pelo inequívoco viés da

ou defensores, uma determinada concepção de qualidade adotada no momento sempre se apresentará como a melhor ou mais adequada e, nesses termos, será defendida. 
"eficiência", numa perspectiva conjunta de "planejamento educacional e econômico". Frequientemente tomados como equivalentes (Risopatron, 1991), essas expressões situariam a eficiência como o melhor investimento - leia-se "o mais barato" ou "rentável" - para o melhor desempenho obtido pela escola, na medida em que "produtos e resultados [possam] ser especificados e mensurados" (Adams, 1993, p. 4).

Adams (1993) descreve ainda outras perspectivas vinculadas à qualidade da educação, relacionadas, por exemplo, ao conceito de processo, compreendendo a "interação entre professores, estudantes, administradores, insumos e tecnologia em atividades educacionais", ou a qualidade como eqüidade (equity), usualmente definida em termos de "oportunidades, distribuição ou conseqüências", cuja falta ou manifestação de forma "injusta" demandariam, além de "políticas eficientes de educação", outras políticas dirigidas a um maior nível de eqüidade". Entretanto, são inegáveis o viés e força da corrente que atrela qualidade a eficiência econômica, e o significado que ganha a percepção dos resultados escolares por esse viés.

Por mais que o autor detecte outros usos e perspectivas em relação ao conceito, a força da eficiência que conjuga a organização escolar a uma lógica econômica parece predominar fortemente nas discussões e no entendimento acerca da qualidade, embasando e orientando o desenho das políticas em educação nos últimos anos e a tônica dos discursos oficiais então veiculados em muitos países - e o Brasil não é exceção.

Não raro, a definição da qualidade em função apenas da eficiência obtida e aferida a partir do desempenho escolar, discriminado em determinados produtos e resultados, parece sugerir que comparações entre entes diferentes - como, por exemplo, uma escola pública de periferia e uma escola particular de elite - poderiam e até deveriam ser feitas quase a despeito do contexto em que se inserem ou dos pressupostos ou critérios que os animam ${ }^{6}$. Mesmo que se façam ressalvas quanto a eventuais equívocos em comparações desse tipo, o que acaba sobressaindo - e é de fato enfatizado - é a crença na objetividade que determinados resultados escolares podem oferecer. Segundo Azanha:

A nossa idéia de escola tem sido, muitas vezes, simplificada. Isso se revela, por exemplo, na própria noção de crise educacional que circula amplamente.

\footnotetext{
${ }^{6}$ Certamente não é esse o caso da abordagem de Celso Beisiegel no livro A qualidade do ensino na escola pública. A seriedade do autor e a importância de sua perspectiva de análise ao longo de toda uma vida de pesquisa educacional não poderiam deixar de mencionar que os artigos ali reunidos "não têm a intenção de recobrir o tema da qualidade do ensino em toda a sua complexidade. Propõem-se apenas colocar em discussão as questões de qualidade vinculadas ao processo de extensão das oportunidades educacionais às classes populares. Em outras palavras, examinam questões relacionadas ao desempenho de alunos, professores, escolas e sistemas públicos de ensino sob a perspectiva das conseqüências da conquista de oportunidades escolares por setores cada vez mais amplos das populações subalternas" (2005, p. 8 - grifos do original).
} 
É comum apontarem-se como evidências da crise alguns resultados escolares como a reprovação e a evasão maciças no $1^{\circ}$ grau, a desarticulação dos diferentes graus de ensino, a prevalência de um ensino verbalista que não prepara para o trabalho. Se realmente esses "fatos" são evidências da crise, a nossa concepção de escola é, inegavelmente, fabril, taylorista, porque apenas leva em conta os "resultados" da empresa escolar. E, para sermos coerentes, as nossas "soluções" também vêm seguindo a mesma linha; clama-se por processos avaliativos que nos habilitem a detectar pontos de improdutividade para que sua eliminação permita redução de custos e, conseqüentemente, obtenção de maior rentabilidade do sistema escolar (1995, p. 73).

É interessante notar que em 1990, quando se publicou o livro onde consta esse excerto, pouco se discutiam no Brasil os grandes sistemas de avaliação educacional como o Sistema Nacional de Avaliação da Educação Básica - $\mathrm{Saeb}^{7}$-, e tampouco seus usos ou sua repercussão, sobretudo quando atreladas à questão da qualidade.

Não se põe em questão o fato de a prática escolar produzir resultados. Aliás, seria inusitado que, após um processo de escolarização, compreendendo as etapas da Educação Básica, por exemplo, não esperássemos alguns resultados, muitos deles óbvios como o aprendizado da leitura, escrita e noções de cálculo ${ }^{8}$. Mas outros tipos de resultados esperados de um processo de escolarização podem não ser objetivos ou claramente mensuráveis através de exames padronizados. Pense-se, por exemplo, que um "resultado" a ser apresentado pela escola é o de formar cidadãos, ou o de formar pessoas "educadas" ou pessoas "felizes" e o que tais expressões possam querer dizer.

Dependendo do tipo de resultado ou produto esperado - ainda que possa haver muitos resultados inesperados ou indesejados -, avaliar a qualidade da educação em função do que ela produz, ou do que possa indicar o que será considerado um desempenho eficiente, pode demandar não só a aferição de seus resultados, mas a avaliação - ou antes a discussão - dos meios pelos quais tais resultados são ou podem ser obtidos e da racionalidade impressa na

\footnotetext{
${ }^{7}$ O Saeb surgiu de uma primeira experiência de avaliação da aprendizagem em larga escala realizada em 1988 nos estados do Paraná e do Rio Grande do Norte, então denominada Sistema Nacional de Avaliação do Ensino de Primeiro Grau - Saep. A partir de 1990, o nome passou a ser Saeb, instituindo ciclos regulares bienais aplicados a uma amostra representativa do alunado.

8 A importância dessa idéia, aparentemente trivial, talvez possa ser melhor apreendida pela noção de pressuposição absoluta que, de maneira geral, diz respeito a "idéias tão fundamentais aos esforços de conhecimento ou da ação humana que sua problematização teria um efeito paralisante com relação a esses esforços. Pense-se, como exemplo de pressuposição absoluta, na idéia da possibilidade de aperfeiçoamento humano. A rejeição dessa idéia inviabiliza a ação educativa. A crença nela, a sua admissão é algo absolutamente inevitável ao educador" (Azanha, 1987, p. 70). Resta analisar e discutir se a educação escolar compreende o aperfeiçoamento humano apenas como a posse de determinadas habilidades como a leitura e a escrita, em principio verificáveis por meio de avaliações em larga escala. Como veremos adiante, uma formação escolar parece requerer algo além da aquisição de certas habilidades fundamentais e indispensáveis.
} 
prática escolar, isto é, o sentido mesmo de uma escola responsável pela formação pública de toda uma população.

Contudo, a ênfase com que medem determinados resultados em termos do desempenho cognitivo de alunos e do impacto que certos aspectos de um processo de escolarização têm no desenvolvimento econômico de uma sociedade evidencia uma maior dificuldade em avaliar - ou talvez devêssemos dizer medir - o quanto a educação escolar favorece ou se relaciona a valores ligados à "formação da cidadania" e a seu livre exercício.

Essa é uma das conclusões a que chegou o Relatório de Monitoramento Global de Educação para Todos da Unesco (2005), cujo tema foi "O imperativo da qualidade" e em que se descrevem dois princípios que caracterizariam "grande parte" das tentativas de se definir qualidade em educação:

O primeiro [princípio] identifica o desenvolvimento cognitivo dos alunos como o principal objetivo explícito de todos os sistemas educacionais. Conseqüentemente, o sucesso dos sistemas ao realizar este objetivo é um dos indicadores de qualidade. O segundo enfatiza o papel da educação na promoção de valores e atitudes de cidadania responsável e no provimento do desenvolvimento criativo e emocional. É mais difícil avaliar e comparar a realização desses objetivos entre países (2005, p. 17 - grifos nossos).

Sublinhe-se o caráter abrangente desse relatório e uma preocupação em mencionar um potencial conflito entre diversas perspectivas em torno da qualidade - o que não significa que tenham sido propriamente discutidas no documento. Embora essa menção seja louvável, ela se configurou antes como um recurso pelo qual se enfatizou uma determinada perspectiva em detrimento de outras, e isso fica patente quando se afirma, por exemplo, que:

Os resultados devem ser avaliados no contexto dos objetivos estabelecidos. São expressos mais facilmente em termos de rendimento acadêmico (algumas vezes sob a forma de testes), porém com maior frequiência e melhor aceitação, em termos de desempenho em exames, embora também tenham sido elaboradas avaliações de desenvolvimento criativo e emocional, assim com de mudanças em valores, atitudes e comportamentos. Outros indicadores das realizações do aluno e de ganhos sociais e econômicos mais amplos podem ser utilizados - um exemplo é o sucesso no mercado de trabalho. É útil distinguir entre desempenho, conquista e outras medidas de resultados - que podem incluir benefícios mais amplos para a sociedade (Unesco, 1995, p. 37 - grifos nossos).

Convém lembrar que exemplos baseados em exames acerca de "valores, atitudes e comportamentos" são mencionados de passagem - ao contrário de dois capítulos reservados à análise de desempenho cognitivo e das diversas menções a esses tipos de resultado e a seus 
eventuais impactos, ao longo das 429 páginas do Relatório. De qualquer modo, fala-se, por exemplo, num importante impacto sobre os cuidados com a saúde por parte dos alunos, em especial à prevenção contra a Aids (p. 44), mas também numa comprovada mudança de comportamento que corrobora e enfatiza a tendência predominante assumida no texto: "anos de educação e aquisição de habilidades cognitivas [ensejaram] retorno econômico e social com relação ao aumento de renda, maior produtividade, tanto em ambientes rurais não agrícolas quanto em ambientes urbanos, maior eficácia no ambiente doméstico e na vida familiar"9 (Jolliffe, 1998; Rosenzweig, 1995 in Unesco, 1995, p. 43).

Nesse documento, o princípio da educação como "promoção de valores e atitudes de cidadania responsável" foi pragmaticamente relegado a um segundo plano, seja pela escassez de resultados em termos da mensuração ou avaliação desse princípio, seja pela ênfase na perspectiva do "desempenho em exames" e em como a escola pode propiciar "o sucesso no mercado de trabalho", que ocupou um espaço incomensuravelmente maior. A partir desse foco adotado na análise, a referência às outras dimensões da educação e de sua qualidade ficaram como simples ressalvas, cujo papel é o de mera figuração ou, quando muito, como aqueles coadjuvantes tão admirados por seus méritos e valores mas que não reúnem as “condições necessárias” para assumir o papel de protagonista da história ${ }^{10}$.

Mesmo quando se questiona - uma pergunta retórica, aliás - se "habilidades cognitivas efetivamente fornecem evidências representativas, ainda que incompletas, da qualidade da escola", isto é, se estariam "relacionadas com o desempenho subseqüente dos estudantes no mercado de trabalho e com a capacidade de crescimento da economia", atestamse as "crescentes evidências de que a qualidade dos recursos humanos medida por escores de testes é diretamente relacionada a ganhos individuais, produtividade e crescimento econômico" (Unesco, 2005, p. 40).

Como qualquer empresa que sobrevive do consumo, é comum que se tomem alguns resultados dos sistemas escolares amplamente veiculados e socialmente valorizados como o principal parâmetro de sua qualidade e que surjam muitas conclusões que apontam unidades

\footnotetext{
${ }^{9}$ Não se põe em questão aqui tais resultados e seus eventuais benefícios à vida privada dos indivíduos, mas apenas como a qualidade acaba sendo reduzida a determinados resultados que assumem a direção e, pretensamente, o sentido da ação escolar. Procuraremos aprofundar a questão ao longo deste e dos próximos capítulos

${ }^{10}$ Lembramos aqui as palavras de Hannah Arendt ao discutir a ação política na modernidade: "não basta fazer certas ressalvas como a de que nem todos os meios são permissíveis ou que, em certas circunstâncias, os meios podem ser mais importantes que os fins, pois tais advertências são feitas à base de um sistema moral aceito $a$ priori e que, como demonstra a veemência das próprias ressalvas, dificilmente poderia ser aceito sem discussão ou então elas mesmas são inválidas pela linguagem e analogia que empregam. Falar de fins que não justificam todos os meios é cair em paradoxo, pois a definição de um fim é precisamente a justificação dos meios, e os paradoxos, embora indiquem perplexidades, jamais as resolvem, e por isso jamais são convincentes” (1995, p. 241).
} 
escolares de maior qualidade - e, portanto, eficientes -, em oposição a uma grande maioria de escolas de qualidade inferior ou mesmo sem qualquer qualidade.

Seja como for, há diferenças significativas entre os vários instrumentos de medição e avaliação do desempenho dos alunos, nacional ou internacionalmente, não só quanto aos métodos de aferição utilizados, mas também quanto a seus objetivos imediatos. Tomando especificamente o caso brasileiro, os exames vestibulares, por exemplo, assim como o Exame Nacional do Ensino Médio - Enem -, não são obrigatórios e, portanto, não podem representar a totalidade de alunos de um sistema naquilo que pretendem medir. Embora use a mesma metodologia e as mesmas matrizes curriculares do sistema que a originou (o Saeb), a Prova Brasil de 2005 procura mensurar os resultados de cada escola em particular, e não propriamente o sistema escolar.

Mas esses diversos exames não se destacam apenas por suas peculiaridades e seus aspectos destoantes, mas também por um propósito comum: de modo general, há um sentido bastante difundido que concebe a qualidade de ensino ou da educação como um produto que se obtém por meio da escolarização. A despeito das inúmeras perspectivas em que se pode compreendê-los, analisá-los e discuti-los, esses resultados são freqüentemente circunscritos ao critério da utilidade, cujo viés inegável é o da satisfação de necessidades e interesses de ordem econômica ${ }^{11}$, e a isso se restringem seu interesse e sua utilidade social.

\subsection{A qualidade mensurada}

Temos visto no Brasil um movimento e uma valorização crescente de políticas de avaliação de sistemas públicos de educação. Por meio de provas em larga escala aplicadas aos alunos, conjugadas a outros instrumentos de coleta de dados, os resultados dessas avaliações são cada vez mais divulgados e, na mesma proporção, tomados como um tipo de descrição mais precisa da realidade educacional brasileira.

Além das iniciativas nacionais preconizadas pelo Inep como o Enem e o Saeb, muitos municípios e Estados da federação criaram nos últimos anos seus respectivos sistemas de avaliação. Para dar apenas três exemplos bastante significativos, o Ceará, São Paulo e Minas

\footnotetext{
${ }^{11}$ Não são poucos os autores que, como Enguita, apontam a ênfase com que a qualidade tem sido tomada como a "eficácia do processo", isto é, "conseguir o máximo resultado com o mínimo custo". Sob essa perspectiva, certos "resultados escolares como as taxas de aprovação, retenção, egressos de cursos superiores e comparações internacionais de rendimento escolar estariam circunscritas à lógica de competição no mercado" (1994, p. 98). Contudo, parece-nos que esse parâmetro preponderante de qualidade transcende um problema que possa ser formulado em termos estritamente econômicos, ainda que necessariamente os englobe.
} 
Gerais. Embora relativamente recente, a história das avaliações sistêmicas no Brasil já apresenta várias facetas e nuances, desde as diferentes metodologias utilizadas até a configuração de um campo de investigação acadêmica voltado para essas questões (Freitas, 2002).

O esforço sistemático pela adoção no Brasil de políticas de avaliação em larga escala remonta ao início dos anos 1990, tornando-se nos meados dessa década um dos eixos centrais das políticas educacionais. Essa perspectiva acaba sendo corroborada pela LDB de 1996, que atesta a importância das avaliações sistêmicas fixando sua obrigatoriedade nos diferentes níveis do sistema educacional e pela participação do Brasil em projetos internacionais de avaliação comparada (Bonamino, 2002). Antes disso, o desenvolvimento do amplo campo de estudos em avaliação - incluídas as avaliações em larga escala de rendimento escolar - se dava de forma truncada e incipiente. Nem o esforço empreendido na década de 1960, em meio às "perspectivas mais tecnicistas em educação", foi suficiente para que a avaliação educacional se consolidasse como área de conhecimento (Gatti, 2002, p. 19).

A estreita relação entre a idéia de qualidade e a forma com que são tomados os resultados de avaliações em larga escala pode ser verificada por uma breve análise do Saeb, recentemente modificado ${ }^{12}$, pela ampla divulgação e visibilidade que ele vem obtendo na última década e também por seu pioneirismo na avaliação de sistemas públicos da educação básica brasileira em proporções nunca antes realizadas. Se em seus primórdios, no início da década de 1990, o Saeb visava a "prover informações para a tomadas de decisão quanto a diversos aspectos das políticas educacionais e também para pesquisas e discussões, a partir da geração e organização de dados sobre o desempenho acadêmico de alunos no sistema e fatores a ele relacionados" (Gatti, 2002, p. 27), a partir de meados da mesma década, a divulgação dos dados do Saeb e mais recentemente da Prova Brasil nos grandes órgãos de comunicação passou a vir associada à idéia de medida da qualidade da educação.

\footnotetext{
12 "A partir de 2005, o Saeb passou a ser composto por duas avaliações, a Avaliação Nacional da Educação Básica (Aneb) e a Avaliação Nacional do Rendimento Escolar (Anresc): 1) A Aneb é realizada por amostragem das redes de ensino em cada unidade da Federação e tem foco nas gestões dos sistemas educacionais. Por manter

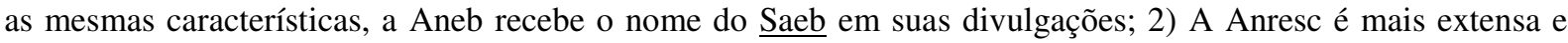
detalhada que a Aneb e tem foco em cada unidade escolar. Por seu caráter universal, recebe o nome de Prova Brasil em suas divulgações." Nesse sentido, a Prova Brasil - cujo propósito é mais abrangente, por divulgar os resultados por escola e não apenas por sistema, como o Saeb, "adota o marco teórico e os mesmos procedimentos e técnicas do Saeb como, por exemplo, matrizes de referência, testes padronizados para medir o que os estudantes demonstram saber e são capazes de fazer nas áreas de conhecimento, padronização dos trabalhos de campo, uso da Teoria de Resposta ao Item e de Escalas de Proficiência para análise de dados e apresentação de resultados". Disponível em <http://www.inep.gov.br/basica/saeb/prova_brasil/metodologia.htm> Último acesso: 29 ago.2006. Neste trabalho, adota-se a mesma nomenclatura utilizada pelo Inep.
} 
É de extremo interesse apontar como a divulgação e a discussão dos dados do Saeb costumam aparecer em veículos de grande divulgação: "Qualidade de ensino caiu entre 1995 e 2001" (Leale, 2002). A respeito da metodologia do exame, outro jornal diz: "O Saeb, realizado a cada dois anos, visa avaliar a qualidade da educação e verificar que fatores interferem no desempenho dos estudantes” (Góis, 2002), e, na mesma edição, afirma-se que: “Quando são analisados os resultados desde 1995, há uma queda na qualidade do ensino em todas as séries" (Góis, 2002). No mesmo sentido, vemos a divulgação que se fez da Prova Brasil e de seus resultados - cuja repercussão parece ter obtido mais destaque do que o próprio Saeb: "Cerca de 5,183 milhões de estudantes de $4^{\mathrm{a}}$ a $8^{\mathrm{a}}$ séries da rede pública farão pela primeira vez neste ano uma prova que permitirá avaliar a qualidade do ensino fundamental e o rendimento do aprendizado por escola e cidade" (Constantino, 2005). Em outra notícia, vemos um exemplo comum de conclusão a que se chega depois de divulgados os resultados: "Os resultados [da Prova Brasil] foram anunciados ontem pelo ministério da Educação (MEC) e mostram que, na média, o ensino brasileiro está longe de um padrão mínimo de qualidade" (Weber, 2006).

Talvez se pudesse alegar que essa imagem da qualidade da educação escolar associada exclusivamente ao desempenho demonstrado pelos alunos é de responsabilidade exclusiva da divulgação e repercussão promovida pela imprensa, certamente superficial e pouco precisa, e que o objetivo do Saeb e de seus formuladores não seria medir tão-somente "o nível de aprendizagem" dos alunos brasileiros em Português e Matemática e correlacioná-lo a determinadas condições, extra e intra-escolares, que poderiam favorecer ou não a proficiência nessas disciplinas. Mas, medir a proficiência ou rendimento escolar dos alunos é a mesma coisa que medir qualidade de ensino ou da educação?

Para além dessas especulações e mesmo do eventual alcance da divulgação dos dados dessas avaliações, é de extrema importância investigar preliminarmente como se explicitam as pretensões do Saeb, a partir do último relatório geral publicado pelo Inep, referente ao ciclo da avaliação realizado em 2001, e também da Prova Brasil:

O Saeb, criado em 1990, constitui-se em relevante instrumento para subsidiar e induzir políticas orientadas para a melhoria da qualidade da educação brasileira. O Saeb avalia a qualidade, a eqüidade e a eficiência do ensino e da aprendizagem no âmbito do ensino fundamental e médio. Aplicado a cada dois anos, utiliza testes e questionários para analisar o desempenho dos alunos e os fatores associados a esse desempenho. Os testes utilizados são elaborados a partir das matrizes de referência construídas para a avaliação do Saeb, tendo como base as Diretrizes Curriculares Nacionais, a Lei de 
Diretrizes e Bases da Educação Nacional (LDB) e as propostas curriculares de todos Estados da Federação ${ }^{13}$ (Brasil, 2002, p. 12 - grifos nossos).

A Prova Brasil foi idealizada para produzir informações sobre o ensino oferecido por município e escola, individualmente, com o objetivo de auxiliar os governantes nas decisões e no direcionamento de recursos técnicos e financeiros, assim como a comunidade escolar no estabelecimento de metas e implantação de ações pedagógicas e administrativas, visando à melhoria da qualidade do ensino ${ }^{14}$ (Brasil, 2002, p. 12 - grifos nossos).

Além da grande coincidência de objetivos entre as duas modalidades de avaliação, os propósitos do Saeb - em que se inspirou posteriormente a Prova Brasil - são mais explícitos ao assumir que avaliam a qualidade do ensino e da aprendizagem ${ }^{15}$. Não se trata de uma concepção isolada. Esse tipo de entendimento da expressão qualidade de ensino ou qualidade da educação também se encontra em falas, por exemplo, de pesquisadores do assunto, como a que aparece num texto com o sugestivo título de "Por uma educação de qualidade". No começo desse texto, ao enfatizar que as políticas educacionais do Brasil têm por objetivo principal atualmente "colocar e manter o aluno na escola", se diz que "A melhoria da qualidade de ensino, no sentido da aprendizagem dos alunos, tem sido relegada a um segundo plano" (Klein, 2003, p. 115-120 - grifos do original). Da mesma forma, Menezes afirma ser a qualidade da educação “o que se avalia nos exames de proficiência” (Menezes, 2007, p. 27). E se poderiam arrolar muitos outros exemplos como esses.

Evidentemente, as avaliações de rendimento escolar não são destituídas de importância e relevância, principalmente por se tratar de uma prática social de interesse público como a educação escolar, o que só aumenta a necessidade de um outro tipo de reflexão e análise que podemos - e devemos - fazer acerca delas. Mas isso não significa que sua utilização tenha ensejado uma mudança significativa na realidade escolar. Aliás, como destaca Gatti, as avaliações com as quais nos deparamos parecem servir:

\footnotetext{
13 Por sua extensão e detalhamento, preferimos usar o relatório de 2001, o último publicado com essas características. De qualquer forma, as pretensões desse exame ainda permanecem as mesmas: "O Saeb é um programa do governo brasileiro com aplicações realizadas a cada dois anos. O objetivo do Saeb é fazer uma avaliação e ao mesmo tempo um acompanhamento da qualidade da educação no nosso País". Disponível em <http://faleconosco.inep.gov.br/resposta.php?cod_item=8580> Último acesso: 12 nov.2006.

${ }^{14}$ Disponível em <http://www.inep.gov.br/basica/saeb/anresc.htm>. Último acesso: 12 nov.2006.

${ }^{15}$ Embora a definição dada pelo Saeb contenha, em contextos diferentes, expressões semanticamente distintas como "melhoria da qualidade da educação brasileira" e de que esse exame "avalia a qualidade [...] do ensino e da aprendizagem no âmbito do ensino fundamental e médio", tais diferenças são de natureza claramente retórica. Não é incomum que qualidade de ensino e qualidade da educação sejam tomadas como equivalentes, como vimos nas divulgações jornalísticas dos resultados dessas avaliações. No entanto, não deixa de ser interessante que se faça uma distinção entre elas, sobretudo quando a pretensão do Saeb de avaliar "a qualidade do ensino e da aprendizagem" se assenta em pressupostos bastante discutíveis como a certeza de que, pelos resultados apresentados pelos alunos, se pode inferir o tipo de ensino ministrado nas escolas. (Essas questões serão abordadas no terceiro capítulo deste trabalho.)
} 
[...] muito mais a um controle, por meio de comparações indevidas, de rankings, para dar assunto "escandaloso" ao gosto dos jornais, do que para estimular soluções educacionais que atinjam as populações necessitadas. [...] As propostas educacionais esparsas que temos passam ao largo das informações avaliativas. A apresentação dos resultados não realiza o que poderia ajudar os professores nas escolas: as análises de cunho pedagógico. Acho até que na maioria dos casos os dados não são visitados, nem estudados, nem refletidos: o que eles nos revelam sobre as necessidades pedagógicas, o currículo escolar, a formação de professores e diretores e como ajudam os gestores a pensar seus planejamentos educacionais? (2007, p. 31).

Ainda que a utilização dos dados de avaliações em larga escala na formulação de determinadas políticas educacionais tenha sido insuficiente ou mesmo nula, seus possíveis efeitos não se limitariam a isso, sobretudo quando as avaliações sistêmicas se afiguram como sendo elas mesmas a própria tradução de uma política educacional. (Oliveira, 2000, Sousa, 2003). Assim, destacam-se não só a vinculação dessas avaliações a um determinado tipo de política, mas também o peso que se lhes atribui socialmente ${ }^{16}$ e principalmente em que sentido se está veiculando o que deve ser a qualidade de ensino, independentemente de eventuais políticas que usem os resultados das avaliações em sua formulação e execução.

A ampla discussão e divulgação do assunto pelos meios de comunicação e também pelos agentes da política educacional nos níveis federal, estadual e municipal aponta para uma definição tácita daquilo que se entende por qualidade de ensino ou educação de qualidade. Em função da objetividade com que resultados escolares são divulgados e discutidos, tem-se a nítida impressão de que se sabe qual é o problema a enfrentar e os valores em que nos devemos pautar para reverter a crise educacional, cuja maior indício parece ser a demanda crescente por avaliações. Se a qualidade da educação deve ser entendida como o melhor desempenho dos alunos segundo as matrizes vigentes, tudo o mais que poderia se associar à qualidade parece perder relevância ou, pior ainda, deixa de ser considerado.

Nesses termos, um dos aspectos que mais chama a atenção no sentido com que se tomam o Saeb e a Prova Brasil refere-se às matrizes curriculares que servem de base para a

\footnotetext{
16 "Como nossas escolas emergiram sob a égide da preparação das elites, a avaliação seletiva no cotidiano escolar firmou-se, por centenas de anos, como cultura preponderante. Mesmo em momentos nos quais aparecem propósitos de democratização das escolas e os primeiros debates sobre a expansão do sistema de ensino, a cultura que dá forma aos processos avaliativos na escola é a que tem como referência critérios altamente seletivos associados a padrões ditos rigorosos, mas sempre pouco claros. [...] Foi essa cultura que se desenvolveu em torno dos processos avaliativos no cotidiano escolar e que, apesar das amplas discussões sobre a questão, permanece até hoje, tendo deixado uma forte marca na vida das pessoas e na representação que fazem da avaliação. Então, o fato de os processos avaliativos estarem sempre presentes no ambiente escolar, em todos os níveis, faz com que as pessoas se reportem de imediato a esse tipo de avaliação quando se fala em avaliação educacional, restringindo seu significado" (Gatti, 2002, p. 17).
} 
elaboração dessas avaliações. A partir de 1995, houve mudanças significativas na metodologia e, posteriormente, nas matrizes curriculares então utilizadas pelo Saeb como parte de um conjunto de medidas implementadas na política educacional brasileira na gestão do Ministro da Educação Paulo Renato Souza (1995-2002). Destacamos, em especial, a introdução da ferramenta metodológica da Teoria da Resposta ao Item - TRI -, que, por sua vez, demandou a formulação das matrizes curriculares de referência (1997) a partir das noções de competências e habilidades.

A partir de então, começou a se consolidar um ponto de referência comum em torno do qual se concentraram as reflexões e discussões do significado de qualidade de ensino. Poderíamos ter um indicio mais claro desse parâmetro de qualidade por meio da definição de "competências cognitivas" e "habilidades instrumentais", cuja posse em relação às disciplinas escolares indicaria um desempenho desejável. Nos termos das matrizes curriculares do Saeb, elas são assim definidas:

Entende-se por competências cognitivas as modalidades estruturais da inteligência - ações e operações que o sujeito utiliza para estabelecer relações com e entre objetos, situações, fenômenos e pessoas que deseja conhecer. As habilidades instrumentais referem-se especificamente ao plano do "saber fazer" e decorrem diretamente do nível estrutural das competências já adquiridas e que se transformam em habilidades (Matrizes Curriculares do Saeb, 1999, p. 9).

Um olhar menos atento poderá atribuir à definição de qualidade do Saeb um caráter científico e, por isso, um ar mais confiável, em função da aparente exatidão de suas definições auxiliares de "competências" e "habilidades" (Azanha, 2006, p. 167). Entretanto, mesmo que tais noções sejam oriundas de alguma teoria psicológica mais consistente - o que não parece ser o caso $^{17}$-, isso é irrelevante, na medida em que nos vemos diante de uma definição geral, e não de uma afirmação pertencente a uma rede teórica claramente definida. Além disso, o contexto de uso e divulgação dessa definição não é destinado a uma comunidade científica e tampouco se caracteriza por ser um interesse meramente teórico de descrição e caracterização de uma determinada realidade. Trata-se antes de um instrumento destinado a orientar políticas

\footnotetext{
${ }^{17}$ Ao analisar o alegado caráter científico das definições propostas pela matriz de competências e habilidades do Enem, Azanha afirma não ser possível "avaliá-las como se fossem definições científicas. Não o são. A referência, no caso das competências, a 'modalidades estruturais da inteligência' é irrelevante do ponto de vista científico, pois é óbvio que, no contexto, essa referência não se vincula a nenhuma teoria explícita de inteligência no corpo da psicologia. Trata-se apenas de encaminhar, aliás confusamente, um propósito para o ensino. É, pois, em termos dos programas práticos que pretendem vincular que essas definições devem ser avaliadas" (2006, p. 165). É interessante notar que as definições de competências e habilidades oferecidas pelas matrizes curriculares do Saeb são muito próximas - e, em certos trechos, idênticas - às do Enem.
} 
educacionais e a organização e o sentido das práticas escolares. Aqui, é de extremo interesse a análise das "definições em educação" que faz Israel Scheffler (1974) em sua obra A linguagem da educação, em especial pela distinção entre definições científicas e definições gerais:

Estamos interessados aqui, de maneira geral, em discursos não-científicos, nos quais se oferecem definições de certas noções educacionais; por exemplo, em afirmações referentes a um currículo, em enunciações de programas e objetivos, em interpretações da educação dirigidas ao público em geral e em debates sobre política educacional. Pouco importa que as definições oferecidas em tais contextos sejam ou não baseadas em autoridade científica; o importante é o fato de serem apresentadas como comunicações de ordem geral efetuadas num contexto prático, e não como afirmações técnicas interligadas a uma pesquisa científica especial com propósitos teóricos (Scheffler, 1974, p. 21 - grifos nossos).

Ao se discutir uma avaliação da qualidade de ensino ou da educação, nenhuma teoria ou instrumental científico seria capaz de assegurar sua adequação, exatidão ou infalibilidade. Ainda que uma definição de qualidade lance mão de conceitos que possam eventualmente ter integrado alguma teoria psicológica da inteligência, não é seu status teórico ou cientifico que está em jogo. Analogamente, tampouco o fato de o Saeb ou a Prova Brasil lançarem mão de procedimentos técnicos sofisticados em sua metodologia e no tratamento estatístico dos dados coletados implica que seus pressupostos ou propósitos sejam técnica ou cientificamente justificados.

O significado de qualidade entendido como o desempenho ou o rendimento escolar - a partir de um conjunto de competências e habilidades que os alunos devem ter - não é formulado e endereçado a uma comunidade restrita de pesquisa, mas a toda a sociedade inclusive professores e clientela escolar -, e é nesses termos que ele deve ser analisado. $\mathrm{Na}$ condição de uma definição geral, sua interpretação é política e seu contexto de discussão, análise e julgamento é eminentemente público.

Nesses termos, até que ponto convém reduzir o significado de qualidade de ensino ou da educação ao que os alunos demonstram saber em termos de competências e habilidades nas disciplinas escolares? Não há aí uma mera descrição do que é qualidade. Sua formulação lingüística e o contexto de sua aplicação e veiculação determinam como as coisas ocorrem ou deveriam ocorrer num determinado sentido (Silva; Bauer, 2005). Trata-se de uma concepção pedagógica largamente difundida atualmente que, segundo Azanha, pode ter: 
[...] graves consequiências pedagógicas, principalmente porque, em alguns textos, competências são contrapostas a conhecimentos, como se as escolas de formação geral (ensino fundamental e ensino médio) devessem se preocupar mais com a constituição daquelas do que com o ensino destes, como se fosse possível tornar-se um matemático competente pelo desenvolvimento de uma "coisa" que se chama "competência matemática", distinta do estudo intensivo de tópicos de matemática, ou, da mesma forma, como se fosse possível alguém tornar-se um competente intérprete de Chopin sem o treinamento continuado na execução de suas obras (Azanha, 2006, p. 181).

Em que pese a confusão conceitual a respeito da noção de competência, pouco discutida e até ignorada pelos agentes institucionais responsáveis pela formulação e implantação das políticas educacionais na ultima década ${ }^{18}$, essa nova opção por uma determinada perspectiva pedagógica e curricular que melhor delimitasse e orientasse o Saeb e seus critérios para a definição de níveis de aprendizagem a aferir guarda estreita ligação com a formulação dos Parâmetros Curriculares Nacionais - PCN - que começaram a ser formulados e veiculados a partir de 1997 (Brasil, 1999, p. 7).

Reforça-se, assim, um discurso que, para além de eventuais repercussões concretas e circunscritas a determinadas ações, sedimenta um ideário de que o que importa é o produto da escola, passível de ser comprovado e medido em avaliações em larga escala, em estrita correspondência com. uma determinada concepção utilitarista de educação, que vê sentido apenas em que o aluno detenha determinadas competências e habilidades requeridas pelo mercado de trabalho. Tais questões referem-se a interesses que se ambientam no debate político acerca do sentido que adquirem as avaliações em larga escala, e não são, como muitos podem supor, uma questão meramente técnica, mais ainda quando apontam para uma determinada visão e concepção de escola e, conseqüentemente, de sua qualidade.

\subsection{A narrativa instrumental da qualidade em educação}

\footnotetext{
18 "Fala-se, e com bastante destaque, ainda que nem sempre de forma consistente, na avaliação de competências e habilidades, mas de modo discutível e muito pouco consensual. [...] As questões que se impõem imediatamente, com o objetivo de aprofundar nossas percepções, podem ser propostas da seguinte forma: são desenvolvidas competências e habilidades em nosso sistema educacional de uma forma sistemática, ou explicitando, é o nosso ensino orientado para o desenvolvimento de competências? Se for, qual a natureza dessas competências e supostas habilidades? Outra pergunta, que também reflete nossa perplexidade: se competências e habilidades foram promovidas, houve efetivamente preparo adequado dos educadores em relação a esse complexo e controvertido assunto? [...] Os programas de pesquisa sobre o Saeb deveriam incluir necessariamente uma parte dedicada a estudos de validade, nas suas diferentes modalidades [validade de conteúdo e validade conseqüencial], evitando-se o tratamento tangencial da questão, como vem ocorrendo em alguns poucos trabalhos que discutem a problemática da avaliação" (Vianna, 2003, p. 8/18).
} 
Identificar a qualidade em educação a partir da eficiência com que determinados produtos e resultados são - ou não - conquistados é uma forma de defini-la, e definições como essa podem ultrapassar a mera descrição de uma determinada realidade educacional ou um uso comum atribuído ao termo definido, algo bastante comum nos discursos pedagógicos. A depender do contexto em que são veiculadas e aplicadas, as definições em educação apontam uma diretriz a ser seguida, uma orientação pela qual a realidade deve se balizar.

A esse respeito, Scheffler (1974) propõe algumas categorias muito pertinentes à análise da linguagem da educação, a partir de uma primeira distinção do que chama de definições gerais presentes no discurso educacional. Estas se dividiriam, primeiramente, em três categorias - estipulativas; descritivas e programáticas -, e cada qual demandaria formas diferentes de apreciação e análise, ocorrendo, inclusive, mais de uma dessas classificações numa mesma definição. Essa dupla avaliação parece se aplicar a muitos casos em que a qualidade da educação é definida a partir do desempenho escolar e de seus resultados vinculados prioritariamente a interesses ou necessidades econômicas da sociedade. É freqüente que a ênfase e o viés com que se tomam certos resultados da educação, ainda que espelhem um entendimento comum de certas características inerentes a um processo de escolarização, transcenda a mera descrição de uma dada realidade. Nesses casos, mais do que espelhar um significado bastante comum atribuído à qualidade, percebe-se a proposição de um programa de ações. Dessa forma:

[...] é a intenção prática da definição numa ocasião particular que revela o seu caráter programático. Uma mesma fórmula que se repete em várias ocasiões poderá, obviamente, ser programática numa delas e não na próxima. Pode-se talvez dizer, com efeito, que uma definição programática veicula a própria conseqüência prática, não se limitando meramente a exprimir uma premissa capaz de produzir, sob condições adequadas, essas conseqüências (Scheffler, 1974, p. 29 - grifo do original).

As definições programáticas, alerta Scheffler, são vinculadas a princípios éticos e políticos, uma vez que "tencionam dar expressão a programas de ação" (1974, p. 29). O que está em jogo nesse uso da expressão qualidade de ensino, além do caráter descritivo de um entendimento bastante difundido de como se mede e do que venha a ser qualidade, é o programa de ação e a força prática que essa definição enseja. É esse papel prático, típico das definições programáticas que, a despeito de qualquer medida ou reforma política eventualmente adotada em seu nome, sedimenta e massifica essa concepção de qualidade, inserindo-se de maneira bem direta "nas práticas sociais e nos hábitos de espírito" (1974, p. 28). 
Não se pode questionar o discurso educacional e pedagógico por apresentar uma inegável função programática. As definições e, de modo geral, as teorias presentes no campo educacional não se prestam apenas a descrever fatos ou a buscar compreendê-los, mas visam também a transformar uma dada realidade - as teorias que abordam novas metodologias de ensino nas mais diversas disciplinas escolares são exemplos disso. Tampouco as matrizes conceituais do discurso educacional são - ou deveriam ser - apenas de cunho pretensamente descritivo, técnico ou científico, como supõem alguns.

Não deixa de ser também programática a veiculação da idéia de que a educação se deve balizar por pressupostos científicos (Carvalho, 2001) ou econômicos. Isso só evidencia uma característica eminentemente política da prática educacional escolar, numa face característica de seu discurso: a disputa entre conceitos e definiçõos utilizadas em relação a uma mesma expressão ou objeto. A existência de diversos significados atribuído ao conceito de educação parece ser o exemplo mais contundente disso.

Em diversas sociedades e tradições, muitas foram as concepções formuladas acerca da educação. Contudo, a arte prática que de forma geral designamos por educação não demandou necessariamente uma teoria educacional para se fazer presente e se perpetuar. Assim, a educação abrangeria duas dimensões: o próprio ato de educar e a constituição de um campo de estudos sistemáticos que a tomam por objeto (Carvalho, 2001, p. 14), Ainda que se perceba a prática da educação como uma característica indissociável da condição humana, a reflexão acerca de seus fundamentos e propósitos foi e é diversificada e, não raro, pouco consensual.

Desde quando o homem se dispôs a refletir sobre essa prática social ancestral, vemos surgir - e cair em desuso - definições e concepções de educação conforme os contextos em que se veicularam e eventualmente debateram e discutiram. Assim, reforça-se a observação de Scheffler (1974) de que, no campo educacional, as definições não devem ser classificadas e tampouco analisadas apenas em sua forma lingüística, pois seria ingênuo supor que sua força prática advenha do modo como se expressa formalmente. Vale aqui o alerta de que:

[...] se estamos tentando analisar um conceito, é importante compreender que isso não pode ser feito adequadamente pelo simples exame do uso de palavras de qualquer modo auto-suficiente. Temos que estudar cuidadosamente sua relação com outras palavras e seu uso em diferentes tipos de sentenças. Uma compreensão de seu uso em sentenças não surge apenas estudando-se gramática; também é necessário compreender os diferentes tipos de propósitos ocultos no uso das sentenças, e isso exige reflexão sobre os diferentes propósitos, lingüísticos e não-lingüísticos, que os seres humanos compartilham em sua vida social (Hirst; Peters, 1972, p. 19). 
Nesses termos, é de extremo interesse aqui a abordagem das próprias matrizes conceituais do discurso educacional e as formas de sua apropriação no que tange à análise das definições gerais em educação. Segundo Carvalho (2000), até o final do século XIX, as reflexões sistemáticas sobre as práticas e os objetivos educacionais foram inspiradas em “doutrinas e concepções filosóficas bastante amplas”, por exemplo, a visão educacional que se pode depreender de filósofos como Platão e Rousseau. Nessa relação entre cânones da filosofia e a prática educacional, procurou-se derivar dessas doutrinas "desde medidas práticas, como diretrizes de trabalho, até certas perspectivas de políticas educacionais", criando assim um "modelo de discurso pedagógico" cujo pressuposto, em termos práticos, é bastante discutível ${ }^{19}$. A partir do século XX, as "matrizes conceituais do discurso pedagógico" vêm se modificando e tendendo cada vez mais às ciências humanas e, de maneira especial, à psicologia (Carvalho, 2001).

Não se trata de ver uma substituição absoluta de uma matriz filosófica por uma matriz científica, mas antes de constatar a força e a ênfase com que o discurso pedagógico procurou incorporar em suas definições um referencial cujo status pudesse ser avalizado por algum ramo da ciência. Talvez os discursos pedagógicos recentes estejam, uma vez mais, mudando sua ênfase, ainda que não se excluam as outras vertentes de cunho filosófico e principalmente científico.

Percebe-se, assim, a sedimentação de uma visão preponderante - mas evidentemente não exclusiva - do que deve ser entendido por qualidade em educação, cujos princípios convergem para uma determinada razão meramente economicista para a educação escolar. Essa racionalidade instrumental aplicada à educação não raro se acompanha da fervorosa prescrição de concepções de ensino e de aprendizagem orientadas por uma alquimia que agrega expressões de mal disfarçado caráter pretensamente psicológico - recurso conhecido do discurso pedagógico -, a princípios da Economia e do mundo corporativo.

Reúnem-se diferentes definições que laçam mão de termos como "competências", "habilidades", "competitividade", "necessidades", "eficiência”, "cidadania" "produtividade", "desenvolvimento" e outros mais que, analisados isoladamente, podem significar diversas coisas, mas cuja conjugação num conjunto de definições que comungam de pressupostos e

\footnotetext{
19 “As evidências lógicas e empíricas de que não há uma conexão necessária ou um conjunto único de conseqüências derivadas da adoção de certas visões filosóficas amplas e teorias ou reflexões sobre os fins e procedimentos da educação não são desprezíveis. Isso não significa, evidentemente, que não haja relação alguma entres esses dois campos. Apenas torna patente o fato de que os problemas educacionais têm especificidades cujo equacionamento exige muito mais do que uma visão geral de mundo. Há certas características das instituições e dos problemas educacionais cuja compreensão não pode ser lograda por simples analogias ou transposições de conceitos de uma área a outra" (Carvalho, 2001, p. 20).
} 
perspectivas confere-lhes status e uso característicos, determinantes para a compreensão e a discussão da qualidade em educação sob uma perspectiva bem delimitada.

O que pode estar em jogo, ao voltarmos nossas crenças, esperanças e objetivos da educação escolar a esses deuses modernos - na feliz metáfora de Neil Postman (2002) travestidos em competências e habilidades inexoráveis do mundo futuro já presentes em nossas vidas? É desejável que a eventual utilidade da escola para o desenvolvimento econômico de uma sociedade - circunscrita e determinada pelo mercado - seja tomada como aquilo de mais valioso e importante a ser feito pela formação de seus habitantes? São justamente os pressupostos e o sentido dessa narrativa impingida à educação escolar, composta de um mosaico de definições que se assemelham ou se complementam, que pretendemos abordar, ao discutir o caráter de uma educação escolar pública:

\begin{abstract}
Com algumas restrições mas com toda a convicção, emprego o termo narrativa como sinônimo de deus, com $d$ minúsculo. Sei que é arriscado fazê-lo não só porque a palavra deus, tendo uma aura de sacralidade, não deve ser usada levianamente, mas também porque evoca uma imagem fixa. Mas a finalidade de tais figuras ou imagens é dirigir nossa mente para uma idéia e, mais precisamente, para um relato; não qualquer tipo de relato, mas um que fala de origens e visiona um futuro, um relato que constrói idéias, preceitua regras de conduta, provê uma fonte de autoridade e, acima de tudo, transmite uma impressão de continuidade e propósito. Um deus, no sentido em que estou usando o vocábulo, é o nome de uma narrativa grandiosa, dotada de suficiente credibilidade, complexidade e força simbólica para nos permitir organizar a vida em torno dela (Postman, 2002, p. 13).
\end{abstract}

A discussão de diferentes perspectivas e definições que, em conjunto compõem essa narrativa para a escola, em especial a escola pública, parece indicar precedência sobre quaisquer outras questões, mesmo que a disposição de fazê-la praticamente inexista no debate educacional atual. Trata-se de voltar à questão dos objetivos a que visa uma educação escolar pública, em busca de sentido em sua razão de ser.

Certamente não padecemos da falta de uma razão pela qual as escolas dêem sentido ao trabalho que realizam (Postman, 2002). Talvez uma das causas de nossa crise educacional resida no fato de existirem diferentes razões que buscam dar sentido ao trabalho escolar, embora boa parte delas sejam incompatíveis entre si. Mas, como em qualquer boa saga, os deuses vão ganhando força e poder à medida que enfraquecem ou derrotam seus oponentes e, assim, deparamos com uma narrativa associada à idéia de qualidade em educação cada vez mais prevalecente e que praticamente procura excluir outras razões pelas quais se forma um ser humano. 
Vejamos alguns exemplos de como se vem expressando recentemente no Brasil essa visão, naquilo que tem de mais marcante:

O fiasco da nossa educação fundamental começa a ser percebido. Há cada vez mais brasileiros sabendo que tiramos os últimos lugares no Programa Internacional de Avaliação de Estudantes (Pisa), uma prova internacional de compreensão de leitura e de outras competências vitais em uma economia moderna (Moura Castro, 2007, p. 9 - grifos nossos).

O significado que possamos ter dessas "competências vitais em uma economia Moderna" pode ser um pouco melhor delimitado. Assim, segundo Rose Neubauer da Silva:

A educação, conseqüentemente, passa a ocupar papel central na pauta das políticas públicas governamentais, sendo entendida como uma necessidade estratégica dos países na promoção do desempenho social e econômico de sua população, condição indispensável para obter sucesso na nova ordem internacional, marcada pela grande competitividade entre os países (Silva, 1993, p. 19).

Concepções como essas têm sido crescentemente veiculadas pela mídia, na mesma proporção em que se configuram cada vez mais como objeto de discussão e investigação mais especializada. Trata-se de um fim tipicamente utilitarista, de caráter técnico e econômico, atribuído à escola e ao que seria seu papel social. Nesse sentido, a educação tem sua razão de ser no desenvolvimento econômico da sociedade e, portanto, na melhor forma de o futuro cidadão se adequar a esse modo de vida. Não parece ser outra a razão pela qual Cláudio Moura Castro, na excerto acima, não emprega termos como "nação" ou "país" - tais termos seriam muito pouco interessantes ou pertinentes à idéia de que vivemos numa "economia moderna", que baliza e norteia nosso mundo e nossa sobrevivência.

Nessa perspectiva, a escola, em seus meandros e propósitos, deve se ater a um fim meramente instrumental, voltado para um futuro supostamente inexorável. Essas "novas demandas" para a educação dariam à escola um "perfil mais nítido" e que poderia "ser traduzido como domínio de contextos, desenvolvimento de habilidades cognitivas e de capacidades sociais" (Silva, 1993, p. 20). Cabe perguntar: que habilidades cognitivas desenvolver? Como se definem e ensinam habilidades cognitivas? O que seriam "capacidades sociais"? Seria alguma espécie de formação para o trabalho ou, tendo em conta a dura realidade atual, alguma capacidade especial para se conviver com o desemprego?

Guiomar Namo de Mello (1993) procura explicitar melhor esse novo referencial para a escola, a partir da formulação e adoção do "conceito de satisfação das necessidades básicas de 
aprendizagem", pela Conferência Mundial de Educação para Todos, realizada em Jomtien, na Tailândia, em março de $1990^{20}$. Esse conceito seria uma orientação "importante para a formulação de políticas, dado o seu caráter objetivo e articulador" (1993, p. 40). Ainda que seja discutível atribuir a esse conceito um caráter claramente objetivo, o que mais chama a atenção é a forma como se vai engendrando uma concepção escolar esvaziada de conteúdo, pautada nos chamados "códigos da modernidade".

E as alegadas "necessidades de aprendizagem”, em sua amplíssima formulação, são necessidades individuais, como se do ponto de vista público e da organização do Estado não houvesse demandas e objetivos tão ou mais valiosos para nortearem a educação. Ainda assim, nessa perspectiva individual, o aprendizado deixa de ser condição de liberdade e se constitui em reino da necessidade. Evidentemente, não de qualquer necessidade, mas daquelas consideradas fundamentais neste mundo ao qual não nos cabe mais do que nos adaptarmos. Desse modo, uma proposta curricular deveria ter:

[...] objetivos cognitivos bastante ambiciosos, menos quanto ao volume de informações especificas e mais quanto ao domínio em profundidade do conteúdo, de modo a desenvolver as capacidades cognitivas de nível superior que o processo de aquisição do conhecimento deve propiciar (Mello, 1993, p. 41 - grifos nossos).

Se aqui ainda persiste uma vaga idéia quanto à "profundidade de conteúdo" - embora este venha subordinado ao que supostamente pode oferecer ao mundo do trabalho -, ela vem ganhando, com passar do tempo, um aspecto mais contundente e o endosso oficial por meio das políticas de reformulação curricular implementadas no Brasil na última década, pautadas pelo domínio de "competências básicas e não no acúmulo de informações", segundo as palavras do ministro da Educação à época da implantação dos PCN (Brasil, 1999, p. 11). Essa compreensão do que deve ser enfatizado no ensino e conseqüentemente avaliado na aprendizagem embasou não só os PCN e as Diretrizes Curriculares Nacionais, mas também as matrizes curriculares do Saeb e da Prova Brasil.

Talvez as pretensões dos sistemas de avaliação em larga escala de medir a qualidade do ensino tenham encontrado nessa narrativa o arcabouço teórico ideal, na medida em que

\footnotetext{
${ }^{20}$ Segundo a Declaração de Jontiem, "Essas necessidades compreendem tanto os instrumentos essenciais para a aprendizagem (como a leitura e a escrita, a expressão oral, o cálculo, a solução de problemas), quanto os conteúdos básicos da aprendizagem (como conhecimentos, habilidades, valores e atitudes) necessários para que os seres humanos possam sobreviver, desenvolver plenamente suas possibilidades, viver e trabalhar com dignidade, participar plenamente do desenvolvimento, melhorar a qualidade de vida, tomar decisões fundamentadas e continuar aprendendo (Pnud/ Unesco, 1991).
} 
qualidade se restrinja à eficiência com que certas competências e habilidades podem ser demonstradas ou àquilo que agora se consideram aprendizagens necessárias:

O conceito de necessidades básicas de aprendizagem é articulador na medida em que focaliza o "núcleo" de todo o processo educativo, ou seja: o ensinoaprendizagem, sugerindo medidas concretas para aferir-lhe a eficiência (Mello, 1993, p. 40).

A ênfase nesse caráter instrumental da educação, sua tradução na expectativa de os alunos adquirirem discutíveis "competências e habilidades" e a ânsia por avaliações sistêmicas que se atenham a elas - no Brasil e em boa parte do mundo - revelam uma preocupação evidente não só de se detectarem comportamentos, mas também de induzi-los e ditá-los. Tudo em nome de um ideal que não vai além da mera instrução, muito mais do que propriamente algo que poderíamos classificar como formação. E isso é concomitante à retórica educacional que costuma acompanhar essa narrativa que, em algumas oportunidades, usa expressões como "eqüidade social" ou "formação da cidadania", no intuito de legitimar a intenção do discurso. Nesse contexto, tais expressões são praticamente desprovidas de significado.

De fato, é bastante questionável, por exemplo, a idéia da educação "como elemento central de uma nova estratégia de desenvolvimento, que conjuga a busca de eficiência econômica com a promoção da eqüidade e da cidadania”, como pensa Maria Helena Guimarães Castro (1999, p. 6). A menos que a cidadania se deva agora pautar por valores como a competitividade ou exclusão daqueles que são considerados inaptos ao modo de vida que busca prioritariamente o lucro e a premiação "dos melhores" (fundamento indissociável da idéia de competitividade) $)^{21}$.

A despeito de quaisquer outras pretensões que possa ter o trabalho escolar ou mesmo de certos pressupostos que o vêm definindo historicamente, essa narrativa em favor de uma qualidade educacional pautada exclusivamente por determinados produtos da escolarização aponta não só uma razão instrumental que justifique o processo de escolarização, mas atrela esse propósito à forma pela qual as escolas devem encarar seu trabalho e encaminhar os meios a serem empregados no ensino, numa dimensão jamais vista.

Ao mencionar essa categoria que aqui denominamos narrativa instrumental da qualidade em educação, não pretendemos aplicar fidedignamente os usos canônicos que o

\footnotetext{
${ }^{21}$ Não é demais lembrar a observação de Hannah Arendt a propósito de uma divisão quase física feita no sistema escolar inglês entre crianças mais e menos dotadas: "A meritocracia contradiz, tanto quanto qualquer outra oligarquia, o princípio da igualdade que rege uma democracia igualitária” (2005, p. 229).
} 
conceito de narrativa tem em outras áreas como a Historiografia ou a Literatura, por exemplo, ainda que alguns desses usos, em suas diversas formas, possam relevar aspectos de especial interesse para esta discussão.

Uma narrativa, qualquer que seja, refere-se a alguma experiência, o que lhe confere algum respaldo e identificação por parte do público a que se destina. A experiência narrada não se restringe ao relato de situações ou feitos únicos e grandiosos, como uma típica narrativa épica ou como um tipo de recorte historiográfico, mas compartilha também um modo de vida, certos valores comungados e cultuados, formas comuns de se verem certas coisas - algo como a imagem do trabalho que a escola deve desempenhar na sociedade -, o que não implica uma descrição objetiva da realidade de um sistema escolar ou do funcionamento de uma determinada escola.

Não é tanto a realidade educacional factual que está em jogo nessa narrativa instrumental da qualidade, mas uma "espécie de sentido" orientado pela experiência subjacente à noção de utilidade atribuída ao processo de escolarização, fortemente compartilhada e vivenciada. Na medida em que é constituída por uma amálgama não só de definições gerais mas também de slogans educacionais, essa narrativa não pode ser tomada com um conjunto de afirmações ligadas a um contexto científico e com propósitos teóricos (Scheffler, 1974, p. 20), assim como a noção de "competências e habilidades" não é veiculada por pertencer - eventualmente e de forma discutível - a alguma teoria psicológica claramente definida ou a alguma outra teoria científica. Tampouco se pretendem provar ou discutir seus pressupostos, mas apenas constatar uma posição e direção a serem impressas à prática escolar e à sedimentação de seu significado social, na medida em que os contextos de seu uso apontam e encaminham um propósito para a educação.

Nesses termos, a exemplo dos slogans educacionais, essa narrativa se circunscreve a um rol de argumentos ou doutrinas literais que a animam e se configura também como a junção de "símbolos que unificam idéias e atitudes-chave dos movimentos educacionais [que] exprimem e promovem, ao mesmo tempo, a comunidade de espírito, atraindo novos aderentes e fornecendo confiança e firmeza aos veteranos" (Sheffler, 1974, p. 46).

Atrelada a essa narrativa instrumental, essa "espécie de sentido" assume uma condição indistinta entre sentido e fim, como sugere Hannah Arendt em sua discussão em torno do conceito antigo e moderno de história. Na verdade, trata-se de uma "degradação" de sentidos em fins, em que "os próprios fins não são mais compreendidos, de modo que, finalmente, todos os fins são degradados e se tornam meios" (2005, p. 114). 
Em última instância, essa "ausência de sentido" teria surgido das filosofias estritamente utilitaristas comuns e características da primeira fase industrial da Modernidade, caracterizada pelo fascínio exercido pelas "novas formas de manufaturar". Assim, começou a se impor aos homens uma forma de pensar as coisas em termos de meios e fins, cuja validade viria da origem e da justificação da experiência de produção de objetos-de-uso (Arend, 2005, p. 114). Assim, o cerne do problema de um significado atribuído à qualidade em educação restrito a determinados desempenhos esperados de um processo de escolarização reside:

[...] na natureza do quadro de referência categórico de meios e fins, que transforma imediatamente todo fim alcançado nos meios para um novo fim, como que destruindo assim o sentido, onde quer que este se aplique, até que, no decurso do aparente interminável questionar utilitarista - "para que serve..." -, em meio ao aparentemente interminável progresso onde a finalidade de hoje se torna o meio de um amanhã melhor, surge a única questão que nenhum pensamento utilitarista pode jamais responder: "E para que serve servir?" (Arendt, 2005, p. 115).

É como se esse questionar utilitarista inerente à narrativa instrumental da qualidade nos convidasse a uma caminhada cujo ponto de partida e as paisagens percorridas fossem desprezíveis em face do ponto de chegada - mesmo que o ponto de chegada seja a inusitada competência e capacidade de caminhar melhor. Os riscos e conseqüências disso já podem ser percebidos: a restrição prática à liberdade das escolas no planejamento e na condução de seu trabalho e, principalmente, a paulatina destituição de outras razões pelas quais se pode formar um ser humano no âmbito de uma instituição escolar voltada para o interesse público.

Talvez seja justamente o caráter público da educação escolar que esteja cada vez mais esvaziado, à custa de uma noção de qualidade educacional estritamente instrumental, ligada a supostos efeitos econômicos e interesses privados, característicos de uma sociedade de consumo. 


\section{2 - ESFERA PÚBLICA E A PERSPECTIVA INSTRUMENTAL DA QUALIDADE}

À medida que uma narrativa instrumental da qualidade em educação reflete uma experiência comum, não é estranha a pouca importância dada ao caráter público de uma formação escolar, como se essa instituição praticamente independesse desse conceito. E o esvaziamento do significado daquilo que é de interesse publico não se restringe ao campo educacional. Pro exemplo, a imagem tão comum da "qualidade superior" da escola particular em relação à escola pública parece integrar um ideário social mais abrangente, que enaltece a eficiência da iniciativa privada na mesma proporção em que deprecia aquilo que é público.

Esse parece ser um dos aspectos mais contundentes do programa prático ensejado pela definição da qualidade educacional determinada apenas por certos resultados considerados úteis ao desenvolvimento econômico da sociedade e à melhor forma de os indivíduos se adaptarem a ela. Ainda que não seja uma concepção exclusiva, a preponderância dessa narrativa instrumental a impõe como objeto desta análise.

Entretanto, deve-se reconhecer que a própria noção de público pode ser ambígua ou apenas vagamente delimitada em seus diversos usos, desde os que se referem aos esforços teóricos e acadêmicos até sua veiculação mais corriqueira e despretensiosa. A polissemia da palavra engendra significados não raro divergentes como, por exemplo, o de que o público estaria estritamente vinculado aos interesses da sociedade e seus diversos grupos ou o de que seria pautado por tudo aquilo que é de propriedade do Estado ou está sob sua tutela.

Por outro lado, podem-se encontrar limites mais indistintos entre o que se toma normalmente como público em contraste com o que é do âmbito privado. Uma universidade pública pertence ao Estado, o que não significa que seu acesso esteja franqueado à totalidade de sua população. Já uma fundação de direito privado que mantenha uma rede de escolas com acesso gratuito a uma pequena parcela da população pode ser considerada de utilidade pública, mas seria estranho, se não equivocado, classificá-la como uma escola pública.

Muitos outros exemplos poderiam ilustrar a dificuldade de se determinar precisamente o que se classifica como público, e esse adjetivo não pode ser tomado necessariamente como sinônimo de interesse ou propriedade estatal. Um Estado pode legislar e atuar em favor de uma pequena parte da população, e a história política brasileira é farta em exemplos desses.

Os diversos usos da noção de público parecem apontar uma disputa, ainda que velada, no que tange ao conceito de qualidade em educação. Nesses termos, a qualidade e seu par antitético - a forte percepção de uma crise educacional - são duas faces da mesma moeda, e o que pode decidir a favor de alguma delas é o próprio entendimento que se tenha do conceito 
de público ou, mais especificamente, do que se entende por uma educação pública de qualidade.

\subsection{O publico e o privado em sua origem}

A identificação da polissemia de uma expressão - como é o caso da noção de público - pode acarretar paralisia ou relativismo. É um risco sempre presente quando o esforço de uma análise como essa se assentar no estabelecimento de um rol exclusivo e "privado", por assim dizer, de significados, ainda que coerentemente organizados. $\mathrm{O}$ denominador comum de uma discussão nesses termos, calcado apenas na garantia de "assegurarmos uns aos outros o direito de nos refugiar em nosso próprio mundo de significados", parece indicar apenas uma forma de intercâmbio de argumentações, mas não propriamente o esforço de compreensão de um "mundo comum a todos nós", como nos lembra Hannah Arendt (2005, p. 132).

É justamente a partir da análise dessa autora da experiência humana que forjou a noção de público - de que somos, em grande medida, tributários - que dispomos de uma perspectiva bastante pertinente para a reflexão acerca das contendas e do sentido que esse conceito - e a própria idéia de uma formação escolar - adquirem atualmente.

Essa "arqueologia" em torno da experiência original de um espaço público - e político - parte do pressuposto de que "os problemas elementares da Política jamais vêm tão claramente à luz, em sua urgência imediata e simples, como ao serem formulados pela primeira vez”, numa referência à forma de vida inaugurada pela pólis grega. Se hoje a noção de público comporta diversos significados, apenas seu início e seu eventual fim são, "por assim dizer, puros ou sem modulação" (Arendt, 2005, p. 44).

Mas não é fácil seguir o estilo de pensamento e argumentação de Arendt. O desafio é não perder de vista que o significado primeiro da noção de público - e, consequientemente, suas transformações históricas e seu(s) sentido(s) atual(is) - não se pode dar de forma estanque em relação a outras categorias fundamentais da análise da autora. Usando a metáfora do jogo de xadrez, embora o conhecimento de suas regras seja condição para jogá-lo, o êxito na empreitada demanda a antecipação do que um determinado lance pode desencadear nos seguintes. Essa atenção às circunstâncias e ao desdobramento do jogo vai muito além do efeito de um movimento isolado, da mesma forma como Arendt situa e analisa a categoria que ela chama de esfera pública - em suas configurações antiga e moderna -, imersa numa rede 
conceitual maior, condição para a compreensão de seus usos e significados atuais, a partir do modo de vida que a originou.

Tanto a origem grega de uma esfera pública como sua contraparte, a esfera privada, estariam indissociavelmente atreladas a determinadas atividades, compreendendo "as condições básicas mediante as quais a vida foi dada ao homem na Terra" (1995, p. 15). Assim, a vita activa é composta de três atividades humanas fundamentais.

A primeira delas é o labor, que diz respeito à vida biológica do corpo humano, assim como aos esforços de preservação da espécie e de seus indivíduos. Trata-se da própria condição de manutenção do ciclo vital de sobrevivência, num movimento pautado pela busca dos recursos necessários à manutenção da vida e sua demanda por consumo, esforço inerente a todo ser humano, assim como a todo animal. A busca e o consumo dos meios de subsistência, o descanso necessário ao corpo, a distração ou o divertimento como necessidade vital e a própria satisfação que tais atividades proporcionam, incluída aí a reprodução da espécie, dizem respeito ao labor e ao animal laborans. "A condição humana do labor é própria vida" (Arendt, 1995, p. 15).

A segunda atividade fundamental é a do trabalho e diz respeito à produção do mundo material e artificial que transcende o ciclo biológico da espécie humana. "A condição humana do trabalho" é a da "mundanidade", isto é, uma atividade cujos produtos garantem durabilidade ao mundo criado pelo homem para além da vida individual como os objetos fabricados e as obras de arte. O homo faber é "mestre de si mesmo e de seus atos" e age pela categoria de meios e fins. O produto do trabalho não é necessariamente um fim em si mesmo; à medida que um determinado produto é concluído e se vê livre do processo de que resultou, pode ser agregado a outro processo de fabricação ou de uso. A atividade do trabalho demanda uma espécie de esfera pública exclusiva, pautada pelo "mercado de troca" de produtos. O contato do homo faber com outros homens se dá em meio à troca de produtos, diferentemente da relação entre pares numa esfera política.

A terceira é a ação, "única atividade que se exerce diretamente entre os homens sem a mediação das coisas ou matérias" (Arendt, 1995, p. 15). A ação se dá em meio à pluralidade, entendida como "a condição da ação humana pelo fato de sermos todos os mesmos, isto é, humanos, sem que ninguém seja exatamente igual a qualquer pessoa que existiu, exista ou venha a existir" (Arendt, 1995, p. 15). Essa singularidade como característica da espécie humana tem estreita relação com a natalidade - "o novo começo inerente a cada nascimento" (Arendt, 1995, p. 17) - e a capacidade de cada indivíduo agir num mundo preexistente, embora totalmente novo para quem nele se inicia. Na medida em que a ação "se empenha em 
fundar e preservar corpos políticos" (Arendt, 1995, p. 16), ela só é possível num espaço público, determinado não por fins meramente utilitários, mas pela liberdade de iniciar algo novo, e por isso imprevisível, junto a outros homens na mesma condição. Embora esteja numa esfera que transcende a necessidade vital ou a utilidade pragmática das condições da vida, a ação depende, em alguma medida, do labor e do trabalho.

Uma vez que as três atividades fundamentais da vita activa constituem as "manifestações mais elementares da condição humana [e ao] alcance de todo ser humano" (Arendt, 1995, p. 13), a autora analisa o modo como elas definem o tipo de espaço que ocupam e de que forma determinam suas circunstâncias ${ }^{22}$. Não se pretende aqui expô-las exaustivamente - se é que isso é possível -, mas apenas determinar seu significado em termos políticos (Arendt, 1995, p. 88). Segundo Eugenia Wagner, a diferença entre labor, trabalho e ação é estabelecida:

[...] pela maneira como essas atividades se realizam, pelo espaço que ocupam na natureza ou no mundo, na esfera privada ou pública, pelo resultado final obtido através da realização das mesmas e pela maneira como os homens se expressam a partir de cada uma delas (Wagner, 2002, p. 64).

Nesse sentido, na pólis grega, a configuração de uma esfera pública contrastava nitidamente com a esfera privada, em função do tipo de atividades que nelas se exerciam. Embora absolutamente distintas, essas duas esferas de alguma forma se complementavam, em meio a uma posição hierarquicamente superior da ação, compreendida como ação política, em relação ao labor e ao trabalho.

Além de uma esfera privada - orientada pela satisfação das necessidades biológicas humanas e dos interesses utilitários pautados por essas necessidades -, o surgimento da cidade-estado possibilitou ao homem "uma espécie de segunda vida" pública, um bio politikós comum a todos os cidadãos - condição restritiva na participação da vida política da pólis ${ }^{23}$. É

\footnotetext{
22 As atividades integrantes da vita activa e o próprio significado dessa expressão não são fruto de uma classificação "puramente teórica" ou arbitrária da autora, mas antes o resultado da reflexão acerca da maneira como os gregos situavam a si mesmos e seu modo de vida. "Arendt enfatizou e sistematizou a distinção entre as três atividades com a finalidade de recuperá-las do esquecimento a que foram submetidas dentro da tradição de pensamento ocidental. Isso não significa que o homem que realiza determinada atividade encontra-se destituído das capacidades correspondentes a outras atividades. Para Arendt, as condições humanas foram dadas ao homem juntamente com a sua vida, independentemente da atividade que este realiza" (Wagner, 2002, p. 138).

${ }^{23}$ De fato, na Antigüidade grega, a cidadania era restrita a uma pequena parcela de seus habitantes, excluindo-se mulheres, crianças, estrangeiros e escravos. Como lembra Arendt, a propósito da igualdade verificada entre os que podiam participar do espaço público, isto é, os cidadãos: "esta igualdade na esfera política muito pouco tem em comum com o nosso conceito de igualdade; significava viver entre pares e lidar somente com eles, e pressupunha a existência de 'desiguais`; e estes, de fato, eram sempre maioria da população na cidade-estado" (1995, p. 42).
} 
dessa diferença fundamental entre aquilo que era próprio do cidadão em sua condição vital (idion) e aquilo que tinha em comum com seus pares (koinon) que se assentam os pressupostos das esferas privada e pública gregas (Arendt, 1995, p. 33).

Todavia, a valorização e a própria constituição de uma esfera pública - equivalente, na pólis grega, a uma esfera política - estavam intrinsecamente ligadas à esfera privada, o que não implicava uma relação de subordinação ao que era estritamente assunto privado. Tratavase antes de uma interdependência, capaz de criar a condição de participação do cidadão no mundo público.

O que impediu que a polis violasse as vidas privadas de seus cidadãos e a fez ver como sagrados os limites que cercavam cada propriedade não foi o respeito pela propriedade privada tal como a concebemos, mas o fato de que, sem ser dono de sua casa, o homem não podia participar dos negócios do mundo, porque não tinha lugar algum que lhe pertencesse (Arendt, 1995, p. 39).

Uma vez assegurado seu lugar no mundo, o cidadão se via liberado das condições impostas pela vida, típicas do labor, como também do caráter utilitário associado ao trabalho, para participar do mundo público e nele agir politicamente.

Arendt destaca esse status atribuído à ação política a partir da perspectiva aristotélica em torno desse modo vida público adotado na pólis, distinto do labor e do trabalho, atividades consideradas indignas de "constituir um 'bios', um modo de vida autônomo e autenticamente humano; uma vez que serviam e produziam o que era necessário e útil, não podiam ser livres e independentes das necessidades e privações humanas" (Arendt, 1995, p. 21).

Era na praça pública da pólis que se exercia a liberdade, possível apenas nesse âmbito da existência humana. A partir de seus limites bem definidos e em função deles, a esfera pública mantinha um nítido contraste com a esfera privada, entendida como "comunidade natural do lar" e decorrente do imperativo da necessidade e do ocultamento, isto é, aquilo que não só não precisa ser visto como nem sequer tem relevância pública.

A polis diferenciava-se da família pelo fato de só conhecer "iguais", ao passo que a família era o centro da mais severa desigualdade. Ser livre significava ao mesmo tempo não estar sujeito às necessidades da vida nem ao comando de outro $e$ também não comandar. Não significava domínio, como também não significava submissão. Assim, dentro da esfera da família, a liberdade não existia, pois o chefe da família, seu dominante, só era considerado livre na medida em que tinha a faculdade de deixar o lar e ingressar na esfera política, onde todos eram iguais (Arendt, 1995, p. 41). 
As atividades voltadas para a sobrevivência ou para os interesses e as especificidades da vida privada não constituíam um meio para o exercício da política, o que equivale a dizer da própria liberdade. Como está "implícito na própria palavra”, e esfera privada implicava estar-se privado das "mais altas e mais humanas capacidades do homem". Assim, um indivíduo que só vivesse no âmbito dessa esfera - como um escravo ou bárbaro - não poderia ser considerado inteiramente humano (Arendt, 1995, p. 47).

Já o termo "público" abrange "dois fenômenos intimamente correlatos mas não perfeitamente idênticos". O primeiro é a aparência, aquilo que pode ser visto e ouvido por todos, que constitui a "realidade do mundo e de nós mesmos", isto é, uma realidade comum. O segundo é o significado de "público" como sinônimo de "mundo", comum a todos que dele participam mas maior e, portanto, diferente "do lugar que nos cabe dentro dele" (Arendt, 1995, p. 61-62). Assim:

[...] o mundo comum é aquilo que adentramos ao nascer e que deixamos para trás quando morremos. Transcende a duração de nossa vida tanto no passado quanto no futuro: preexistia à nossa chegada e sobreviverá à nossa breve permanência. É isso o que temos em comum não só com aqueles que vivem conosco mas também com aqueles que aqui estiveram antes e aqueles que virão depois de nós. Mas esse mundo comum só pode sobreviver ao advento e à partida das gerações na medida em que tem uma presença pública. É o caráter público da esfera pública que é capaz de absorver e dar brilho através dos séculos a tudo que os homens venham a preservar da ruína natural dos séculos (Arendt, 1995, p. 65).

Não se trata de uma referência a um lugar físico. O mundo significa antes a realidade humana comum, vista, ouvida e discutida por todos que dela participam, separando e ao mesmo tempo estabelecendo "uma relação entre os homens". Relaciona-se com o produto da mão humana - obtidos pela atividade do trabalho ${ }^{24}$-, à medida que esse produto ganhe visibilidade e reconhecimento públicos como uma escultura, uma obra arquitetônica ou mesmo um objeto cuja utilidade evidencie a criatividade humana.

É a partir dessa interação e do diálogo que se estabelece uma esfera capaz de garantir e fomentar um elo comum entre os cidadãos. "Espaço potencial da aparência entre homens que agem e falam" (Arendt, 1995, p. 212), a esfera pública assegurava aos cidadãos uma condição comum para ouvir, julgar, defender e convencer seus pares de seus pontos de vista ou por eles

\footnotetext{
${ }^{24}$ Segundo Wagner (2002), a tradução de labor e work por labor e trabalho pode não ser a mais fiel à argumentação de Arendt, sobretudo porque em português essas duas palavras podem ser tomadas como sinônimas em muitos de seus usos. A palavra work equivaleria à poiesis, ao ato de se produzirem utensílios, uma escultura ou mesmo uma obra intelectual como um poema. Assim, work tem o sentido de "fabricação", diferente do significado que Arendt atribui ao labor. Contudo, optamos por seguir a única tradução disponível no Brasil de A condição humana.
} 
ser convencido. Um espaço comum mantido por meio do diálogo e da igualdade entre aqueles que o constituíam, mas não da violência; onde o interesse público não se dava à custa da singularidade de cada cidadão ou de suas peculiaridades, mas justamente em função dessa diversidade. Portanto, a esfera pública na pólis não implicava um comportamento comum ou uma necessária coincidência de opiniões entre aqueles que dela participavam, mas a possibilidade da distinção que um cidadão poderia atingir mediante suas palavras e ações ${ }^{25}$, imprimindo no mundo a marca de sua presença.

A realidade comum aos cidadãos era constituída não sobre um mesmo ponto de vista, mas pela pluralidade que advém da singularidade de cada indivíduo. Assim, a esfera pública não se distingue pela coesão entre as diversas opiniões e posicionamentos de cidadãos, mas a pluralidade de visões e opiniões num espaço comum igualmente acessível a todos eles.

Na qualidade de espaço privilegiado da ação política, a esfera pública constituía, na pólis grega, o meio comum que vinculava os cidadãos a seus antepassados e às gerações futuras, garantindo a "durabilidade do mundo" e a "imortalidade dos homens". Compreendia a reunião dos cidadãos que, em suas ações e por suas obras, emprestavam durabilidade ao mundo e aos feitos e palavras que pudessem perdurar como lembrança, memória e história.

Era a ação politica numa esfera pública que poderia dignificar e alçar à gloria algum feito humano, tornando-o perene entre os mortais, o que difere bastante de muitas das noções fortemente associadas hoje à política - desonestidade, interesses privados e escusos ou apenas um meio de ganhar a vida -, marcando a dignidade da ação política na pólis grega.

Tanto para os gregos como para os romanos, não obstante todas as diferenças, o fundamento de um organismo político era dado pela necessidade de vencer a mortalidade da vida humana e a futilidade dos feitos humanos. Fora do organismo político, a vida do homem não era apenas nem primariamente insegura, isto é, exposta à violência de outrem; era desprovida de significado e de dignidade, porque sob circunstância alguma poderia deixar quaisquer traços atrás de si (Arendt, 2005, p. 104).

É na busca da imortalidade e, conseqüentemente, na preservação da memória que se encontra o alicerce da ação política. Assim, não estranha que os gregos louvassem "o amor ao belo e a cultura da mente" num mundo público na mesma proporção em que pouco

\footnotetext{
${ }^{25}$ Dentre todas as atividades humanas, consideravam-se políticas apenas a ação (praxis) e o discurso (lexis) constituintes do que Aristóteles denominava bios politikos -, o que excluía tudo o que fosse necessário ou útil. "O pensamento era secundário no discurso; mas o discurso e a ação eram tidos como coevos e coiguais, da mesma categoria e da mesma espécie; e isso originalmente significava não apenas que todas as ações políticas, na medida em que permanecem fora da esfera da violência, são realmente realizadas por meio de palavras, porém, mais fundamentalmente, que $\mathrm{o}$ ato de encontrar as palavras adequadas no momento certo, independentemente da informação ou comunicação que transmitem, constitui uma ação (Arendt, 1995, p. 34).
} 
valorizavam o trabalho de artesãos e artistas, cujo ofício era o da fabricação desses objetos. A imortalização do mundo por meio das artes que proporcionam aos homens a lembrança de seus feitos e palavras era parte da esfera pública, ao contrário do trabalho do artista, atento à realização das obras que lhe garantiam o sustento, a manutenção de sua vida, alheia a essa esfera $^{26}$

A necessidade como imperativo da esfera privada e expressão nítida dos assuntos domésticos - como a economia ${ }^{27}$ - configurava um fenômeno pré-político, excluído, portanto, do mundo público. Há aí aqui uma diferença marcante entre o modo de vida da pólis e a organização política moderna, foco principal da análise empreendida por Arendt em $A$ condição humana.

Não é irrelevante que na pólis grega o mundo público não se interessasse pelos assuntos próprios da esfera privada. O que se destaca nessa esfera pública é a equivalência da ação política a um modo de vida não submetido às necessidades impostas à condição humana.

Deve-se ressaltar, entretanto, que o constante recurso de Arendt às analogias com a experiência política clássica não se pauta por um desejo idílico e irreal de retorno ao que fora a pólis nem se confunde com algum tipo de exortação à transformação da sociedade num determinado sentido. As concepções de progresso ou decadência humanas através da história, em si mesmo valorativas, ou a idéia de que poderíamos reviver ou reproduzir a pólis grega não estão absolutamente presentes em sua argumentação, assim como ela tampouco pretende responder a problemas políticos, pois respostas desse tipo "só podem ser dadas no âmbito da política prática, sujeitas ao acordo de muitos; jamais podem se basear em considerações teóricas ou na opinião de uma só pessoa" (Arendt, 1995, p. 13).

Seu exercício de situar o modo de vida e os valores que antecederam a tradição de pensamento ocidental na pólis pré-filosófica ${ }^{28}$ revela a preocupação de reunir elementos analíticos e conceituais que permitam uma compreensão do mundo atual, isto é, dos fatos,

\footnotetext{
26 "Não havia, no entender dos gregos, nenhuma contradição entre o louvor da philokaléin, o amor à beleza, e o desprezo por aqueles que produziam o belo. A desconfiança e o efetivo desprezo pelos artistas surgiram de condições políticas: a fabricação das coisas, incluindo a produção de arte, não pertence ao âmbito das atividades políticas; põe-se, até, em oposição a elas. O principal motivo da desconfiança em todas as formas de fabricação é que esta é utilitária por sua própria natureza" (Arendt, 2005, p. 269).

${ }^{27}$ Arendt conta como seria impensável na pólis grega tratar de assuntos de ordem econômica em âmbito político, na medida em que "o próprio termo 'economia política' [seria], de certa forma, contraditório: pois o que fosse 'econômico', relacionado com a vida do indivíduo e a sobrevivência da espécie, não era assunto político, mas doméstico por definição" (1995, p. 38).

28 A expressão "polis pré-filosófica" é usada por Wagner (2002) para estabelecer um limite claro entre a experiência política prática da pólis grega e o sentido que adquire a filosofia, notadamente a partir de Platão, distanciada dessa realidade mundana pela busca de uma verdade que a transcendesse. Reside aí a oposição destacada por Arendt entre vita activa e vita contemplativa, que marcou a tradição de pensamento ocidental.
} 
eventos e o modo de vida característicos do mundo moderno. Trata-se do esforço de "refletir sobre o que estamos fazendo" (Arendt, 1995, p. 13).

É na direção e no resultado dessas transformações históricas e da identificação dos interesses sociais atualmente vigentes no espaço público que se destacam alguns aspectos fundamentais para a compreensão do sentido da narrativa instrumental da qualidade em educação e da ampla adesão com que ela conta de vários segmentos sociais, inclusive setores governamentais.

\subsection{O esvaziamento da esfera pública}

O recurso à análise da vita activa a partir do modo de vida desenvolvido na pólis grega não perde de vista que as atividades mais elementares da condição humana - labor, trabalho e ação - são "permanentes, isto é, que não podem ser irremediavelmente perdidas enquanto não mude a condição humana" (Arendt, p. 14), mas essa condição não se limita às circunstâncias em que a "vida foi dada ao homem" e tampouco tem um caráter necessariamente determinado. Em meio a essas condições "naturais", o homem cria suas próprias condições, com mesma força e intensidade.

O que quer que toque a vida humana ou entre em duradoura relação com ela assume imediatamente o caráter de condição da existência humana. É por isso que os homens, independentemente do que façam, são sempre seres condicionados. Tudo que espontaneamente adentra o mundo humano, ou para ele é trazido pelo esforço humano, torna-se parte da condição humana. $\mathrm{O}$ impacto da realidade do mundo sobre a existência humana é sentido e recebido com força condicionante (Arendt, 1995, p. 17).

Assim, a condição humana - em parte inerente ao homem, em parte criada por ele aponta as transformações históricas que determinaram uma nova configuração da vita activa, acarretando outra valoração e hierarquização das atividades fundamentais e dando as origens da alienação no mundo moderno. E talvez essa seja uma das razões pelas quais Arendt não trilhou o mesmo caminho das escolas filosóficas que, desde Platão, se debruçaram sobre a política e as demais atividades da vita activa como inferiores à contemplação e ao modo de vida filosófico atento à revelação da verdade, pois, a partir desse "enorme valor da contemplação" na tradição de pensamento político inaugurado pelos ensinamentos de Platão e Aristóteles, obscureceram-se "as diferenças e as manifestações no âmbito da própria vita 
activa" (Arendt, 1995, p. 25). Daí que a autora se volte não para a busca da verdadeira política, mas para uma compreensão teórica da ação em sua condição de experiência real, da mesma forma que localiza as outras atividades da vita activa - labor e trabalho - no modo de existência característico da pólis.

Dada a oposição entre a vita ativa e a vita contemplativa - proporcionada pela filosofia, alegadamente superior ao labor, ao trabalho e à ação -, não parece ter sido contingente o fato de se ter traduzido, ainda na Antigüidade, "política" pela palavra "social", de origem latina: "Melhor do que qualquer teoria complicada, essa substituição inconsciente do social pelo político revela até que ponto a concepção original grega de política havia sido esquecida" (Arendt, 1995, p. 32).

Essa dimensão "social" da vida humana começa a assumir uma importância sem precedentes a partir do que Arendt considera o começo do declínio da tradição de pensamento ocidental com o início da Era Moderna ${ }^{29}$, que foi marcado pela até então inédita posição hierarquicamente superior atribuída ao homo faber. Dentre os fatores que teriam determinado essa inversão, destaca-se a nova maneira de se fazer ciência - com o advento do telescópio, inventado por Galileu -, o que de alguma forma abalou a confiança naquilo que o homem observava como fundamento da tradição, isto é, nos sentidos humanos como meios para o estabelecimento de verdades eternas ${ }^{30}$.

A própria vita activa, a partir da tradição de pensamento que se iniciou com a filosofia grega, já não era mais percebida em suas três atividades peculiares e complementares - labor, trabalho e ação -, como se, ao adentrar a modernidade, seu significado fosse indistinto, confundido-se "ao agir no mundo dos negócios humanos - ao fazer em geral" (Wagner, 2002, p. 92). Dessa forma:

A vita contemplativa foi abolida e esse foi o motivo pelo qual a inversão entre o pensar e o fazer, ocorrida na própria realidade, já não pôde mais corresponder à inversão entre a vita activa e a vita contemplativa. A

\footnotetext{
29 "A era moderna não coincide com o mundo moderno. Cientificamente, a era moderna começou no século XVII e terminou no limiar do século XX; politicamente, o mundo moderno em que vivemos surgiu com as primeiras explosões atômicas" (Arendt, 1995, p. 13). Destacamos a expressão "mundo moderno" como feição e o contorno mais atual da era que lhe deu origem, pois não é incomum encontrarem-se diversas expressões e significados referentes mais ou menos ao mesmo período como "era da informação" ou o polêmico conceito da "pós-modernidade". Entretanto, a impressão que se tem é que, seguindo Arendt, nunca fomos tão modernos.

30 Arendt destaca alguns eventos que, embora integrantes de um mundo "pré-moderno" - portanto ainda fortemente arraigados na tradição -, foram determinantes para a inauguração da nova era que se iniciava: "No limiar da era moderna, há três grandes eventos que lhe determinaram o caráter: a descoberta da América e a subseqüente exploração de toda a Terra, a Reforma que, expropriando as propriedades eclesiásticas e monásticas, desencadeou o duplo processo de expropriação individual e acúmulo de riqueza social, e nova ciência, que considera a natureza da Terra do ponto de vista do Universo" (Arendt, 1995, p. 260).
} 
atividade de pensar passou a ser serva da ação - da ação entendida como o agir do homo faber (Wagner, 2002, p. 80).

A ação do homo faber - o trabalho ou a fabricação - dá algumas características que têm marcado a Era Moderna como "a confiança no caráter global da categoria de meios e fins", a redução de todo assunto humano ao princípio de utilidade, a "instrumentalização do mundo" e o modo natural de identificar a fabricação como a ação humana por excelência (Arendt, 1995, p. 318).

Contudo, a passagem da fabricação de objetos de modo artesanal para o industrial e depois para um tipo de trabalho mecanizado e a constituição de uma sociedade de massas enfatizaram não mais a atividade do homo faber, mas a do animal laborans. É nesse sentido que, à custa do paulatino esvaziamento das esferas publica e privada, se consolida uma esfera social. Sua gradual ascensão define as diferenças fundamentais entre a concepção de espaço público na pólis grega e sua nova configuração iniciada na Era Moderna.

\begin{abstract}
A mais clara indicação de que a sociedade constitui a organização pública do próprio processo vital talvez seja encontrada no fato de que, em tempo relativamente curto, a nova esfera social transformou todas as comunidades modernas em sociedades de operários e assalariados; em outras palavras, essas comunidades concentraram-se imediatamente em torno da única atividade necessária para manter a vida - o labor. (Naturalmente, para que se tenha uma sociedade de operários, não é necessário que cada um dos seus membros seja realmente um operário ou trabalhador - e nem mesmo a emancipação da classe operária e a enorme força potencial que o governo da maioria lhe atribui são decisivas nesse particular; basta que todos os seus membros considerem o que fazem primordialmente como modo de garantir a própria subsistência e a vida de suas famílias.) A sociedade é a forma pela qual o fato da dependência mútua em prol da subsistência, e de nada mais, adquire importância pública, e na qual as atividades que dizem respeito à mera sobrevivência são admitidas em praça pública (Arendt, 1995, p. 56).
\end{abstract}

Na esfera social, a atividade mais valorizada e almejada é o labor, e não a ação política. No mundo moderno - mais recente e no qual nos encontramos -, fica patente essa inversão da valoração das atividades constituintes da vita activa. Essa mudança tem seu divisor de águas na Revolução Industrial, à medida que o processo produtivo se inclinou cada vez mais para a produção de bens de consumo, amplificando o ciclo vital do labor para uma escala social, e não mais individual. Cada vez mais se produz almejando o aumento de consumo e cada vez mais se consome, num apetite sem limites, voltado para o desejo de continuar consumindo.

Desde o advento da sociedade, desde a admissão das atividades caseiras e da economia doméstica à esfera publica, a nova esfera tem-se caracterizado 
principalmente por uma irresistível tendência a crescer, a devorar as esferas mais antigas do político e do privado, bem como a esfera mais recente da intimidade. Esse constante crescimento, cuja aceleração não menos constante podemos observar no decorrer de pelo menos três séculos, é reforçado pelo fato de que, através da sociedade, o próprio processo da vida foi, de uma forma ou de outra, canalizado para a esfera pública (Arendt, 1995, p. 55).

O labor como esforço de sobrevivência e busca da satisfação das necessidades básicas e imediatas dos indivíduos deixa de ser um aspecto característico da vida privada e, emancipando-se, ganha relevância pública, mesclando-se a essa esfera da vida humana ${ }^{31}$. Assim, ao invés da ação política e do consequiente convívio com os iguais, a preocupação vigente volta-se para a melhor forma de se "ganhar a vida", como se costuma se dizer, e o "bem supremo" valorizado pela sociedade é "vida terrena dos indivíduos e da família".

Essa valorização daquilo que é por definição privado não se restringe ao que os indivíduos fazem e conquistam na estrita dimensão de sua própria vida, mas tudo o que diz respeito a essa esfera atrai interesse e a transcende; por exemplo, o culto à vida das assim chamadas celebridades, que não deixa de ser uma expressão do esvaziamento das esferas pública e privada.

Nesse sentido, a moderna concepção de sociedade não constitui de forma alguma uma ocupação mais ampla do espaço público. A ascensão da esfera social à custa do esvaziamento das esferas pública e privada indica não exatamente a completa eliminação dessas esferas, mas sua gradual e indisfarçável perda de densidade e relevância, o que é um "fenômeno relativamente novo, cuja origem coincidiu com o surgimento da era moderna e que encontrou sua forma política no Estado Nacional" (Arendt, 1995, p. 36).

Como marca de nossa época, o espaço público é tomado por uma profusão de grupos e interesses restritos, particularizados, todos compreendidos pelo difuso conceito de sociedade. Conseqüentemente, a própria ação política, cuja condição é a de ser exercida na esfera pública, acaba assumindo o papel de uma função da sociedade e a ela subordinada.

\footnotetext{
${ }^{31} \mathrm{O}$ desencadeamento daquilo que seria natural, proporcionado pela ascensão da esfera social, isto é, daquilo que diz respeito às necessidades vitais humanas, deu-se à custa do "aumento constante e acelerado do trabalho (labor). O fato isolado mais importante nesse aumento contínuo foi, desde o início, a organização da atividade do labor, visível na chamada divisão do 'trabalho', que precedeu a revolução industrial e na qual se baseia até mesmo a mecanização dos processos de labor. [...] Uma vez que o próprio princípio organizacional deriva claramente da esfera pública, e não da esfera privada, a divisão do trabalho é precisamente o que sucede à atividade do labor nas condições da esfera pública e que jamais poderia ocorrer na privatividade do lar" (Arendt, 1995, p. 57). A autora alerta que a expressão "divisão do trabalho" se aplica "às modernas condições de trabalho, nas quais uma atividade é divida e atomizada em um sem número de pequenas manipulações”, e não como uma divisão ocasionada pela "especialização profissional”.
} 
O fato de que a política é apenas uma função da sociedade - de que a ação, o discurso e o pensamento são, fundamentalmente, superestruturas assentadas no interesse social - não foi descoberto por Karl Marx, pelo contrário, foi uma das premissas axiomáticas que Marx recebeu, sem discutir, dos economistas políticos da era moderna. Essa funcionalização torna impossível perceber qualquer grande abismo entre as duas esferas; e não se trata de uma questão de teoria ou de ideologia, pois, com a ascendência da sociedade, isto é, a elevação do lar doméstico (oika) ou das atividades econômicas ao nível público, a administração doméstica e todas as questões antes pertinentes à esfera privada da família transformaram-se em interesse 'coletivo'. No mundo moderno, as duas esferas constantemente recaem uma sobre a outra, como ondas no perene fluir do processo da vida ${ }^{32}$ (Arendt, 1995, p. $42-$ grifo nosso).

A sociedade moderna compõe uma esfera híbrida, "na qual os interesses privados assumem importância pública”, e, assim, a esfera pública cede espaço e importância ao jogo estabelecido entre os diferentes entes sociais, alguns notadamente mais poderosos e influentes que outros. Não que a ação política não seja possível, mas o esvaziamento da esfera pública como espaço da ação humana em função da crescente importância da esfera social restringe a condição de exercício da liberdade, isto é, a própria possibilidade da ação política. Nesses termos, a liberdade parece ser exatamente o oposto da maneira pela qual:

[...] a sociedade [moderna] espera de cada um de seus membros um certo tipo de comportamento, impondo inúmeras e variadas regras, todas elas tendentes a 'normalizar' os seus membros, a fazê-los 'comportarem-se', a abolir sua reação espontânea ou a reação inusitada (Arendt, 1995, p. 50).

Nessa perspectiva, pode-se verificar como a grande narrativa atual, que se pretende hegemônica, em torno da qualidade em educação está fortemente vinculada a certas expectativas "da sociedade" e de suas "necessidades" econômicas, na mesma proporção em que oblitera a formação do futuro cidadão entendida como formação política que propicie a ação humana, isto é, que o libere dos ditames da necessidade e lhe permita adentrar a esfera da liberdade. O comportamento acaba tomando o lugar da ação como principal forma de relação humana, o oposto da igualdade e do livre agir proporcionados pelo espaço público forjado pela experiência política da pólis (Arendt, 1995, p. 51).

\footnotetext{
${ }^{32}$ A autora foi uma crítica contundente de Karl Marx, ainda que nele reconhecesse um grande intelectual e por isso o respeitasse. Não pretendemos acompanhar a autora nessa crítica - aliás, não teríamos a mínima condição em fazê-lo., mas a escolha da passagem citada não foi de todo despretensiosa, sobretudo pela constatação de que grande parte das críticas ao discurso da qualidade como uma "faceta do neoliberalismo" - como abordaremos a seguir - parte de pressupostos marxistas, oriundos do próprio Marx ou, o que talvez seja mais comum, de seus comentadores. De todo modo, no que possa interessar à análise da educação escolar, o quadro conceitual proposto por Arendt parece-nos mais abrangente e sem dúvida mais profícuo quanto à compreensão de suas características institucionais peculiares e da crise em que se vê permanentemente imersa, no mundo moderno.
} 
$\mathrm{Na}$ sociedade moderna, a ação, antes reino da liberdade, vai se tornando uma modalidade de fabricação orientada pelo labor, e essa parece ser a raiz da dificuldade de se pensarem e discutirem muitos assuntos de interesse público e também assuntos privados, sem:

[...] que se empregue a categoria de meios e fins e se raciocine em termos de 'instrumentalidade'. [...] Somos talvez a primeira geração a adquirir plena consciência das conseqüências fatais de um modo de pensar que nos força a admitir que todos os meios, desde que sejam eficazes, são permissíveis e justificados quando se pretende alcançar um fim (Arendt, 1995, p. 241).

De fato, não é estranho que a atual literatura educacional reconheça a qualidade pelos efeitos de uma determinada escola, programa ou sistema educativo (Risopatron, 1991), pois é nessa razão instrumental que se sedimenta um parâmetro de qualidade cuja justificação é socialmente valorizada e validada, na medida em que serve a um fim marcado por interesses não de uma esfera pública e comum, mas de uma esfera social difusa e materialmente desigual, não obstante orientada por um determinante comum: o consumo e a categoria de meios e fins subordinada ao labor.

Nesse mesmo sentido, a cultura ${ }^{33}$ e os bens culturais - que não são exatamente propriedade estatal, mas são autêntica e inegavelmente bens públicos e, portanto, objetos preferenciais da atividade escolar -, se vêem ameaçados, à medida que são, cada vez mais, "tratados como meras funções para o processo vital da sociedade, como se aí estivessem somente para satisfazer alguma necessidade" (Arendt, 2005, p. 261). Um exemplo contundente disso é a naturalização do fato - bastante comum em escolas de ensino médio -, de se lerem resumos de grandes obras da literatura, úteis, na medida em que presumivelmente facultam êxito em exames vestibulares, ao invés da valorização do contato vivo, enriquecedor e insubstituível com a obra literária.

Se a atividade humana mais valorizada na sociedade moderna diz respeito ao labor, à garantia da sobrevivência e das satisfações imediatas dos indivíduos - incluindo-se o lazer e o entretenimento -, o cidadão assume o papel de simples consumidor, marcado pela atitude que "condena à ruína tudo que o toca", como é típico do processo metabólico orientado para sua própria manutenção, como uma fornalha que não faz distinção entre um resto de madeira e uma pilha de livros clássicos, testemunho da criatividade e da beleza humanas: todos igualmente se inflamam e produzem fogo.

\footnotetext{
${ }^{33}$ Segundo Arendt, a cultura se relaciona com objetos e, nesses termos, consiste num fenômeno do mundo. Entretanto, um determinado objeto pode ser cultural "na medida em que pode durar; sua durabilidade é o contrário mesmo da funcionalidade, que é a qualidade que faz com que ele novamente desapareça do mundo fenomênico ao ser usado e consumido" (2005, p. 260).
} 
É assim que a forte presença de uma narrativa da qualidade com base no que se considera útil aos interesses do animal laborans não deixa de ser uma determinação de fins cujo caráter engendra interesses que dificilmente se poderiam dizer públicos.

Essa verdadeira confusão entre a esfera social e esfera pública num todo aparentemente indistinto não é alheia à percepção da vocação da instituição escolar e de sua responsabilidade, ao menos legal, de formar cidadãos. Um forte indício disso é o apelo aos ditos "interesses da sociedade", quase em oposição à organização estatal como a instância atualmente responsável - e na atual configuração social, talvez a única - capaz de assegurar e proteger a existência de uma esfera pública, isto é, de um mundo comum.

Não é o caso, aqui, de se analisarem o papel do Estado ou a importante distinção entre Estado e governo, mas antes de se pôr em relevo em discussão um pressuposto da narrativa instrumental da qualidade: o de que a esfera social, com seus diversos grupos e contornos, pode ser tomada automática ou necessariamente como a encarnação do interesse público. Vejamos um exemplo eloqüente de uma concepção como essa no campo educacional:

\begin{abstract}
A escola pública de qualidade para todos, objeto de minha ação e reflexão, vício e paixão, não será estatal porque será realmente pública e portanto não monopolizada, conforme eu imaginava há pouco mais de uma década, por este Estado que temos hoje no Brasil nem por nenhum outro Estado. [...] descobri que a escola de qualidade será viva e real no dia em que for efetivamente apropriada pela sociedade como um todo e deixar de ser presa fácil dos políticos em plantão e suas insaciáveis clientelas, dos partidos políticos e suas ideologias intransigentes e redentoras, das corporações e seus interesse estreitos e imediatistas, dos intelectuais e educadores e seus modismos doutrinários e pedagógicos (Mello, 1998, p. 25).
\end{abstract}

A idéia de que a qualidade e o caráter público da educação - mais precisamente as escolas públicas - sejam orientados pela sociedade certamente pode parecer a alguns bastante sedutora, nestes tempos em que o status de público é tão frequentemente associado à ineficiência. Contudo, a crítica ao serviço educacional estatal e a seus problemas de gestão e organização não justifica que a sociedade - em sua configuração difusa e desigual - assuma e determine sua orientação ou mesmo que se responsabilize integralmente por essa tarefa.

Sem dúvida, a sociedade é depositária dos diversos interesses de seus inumeráveis grupos, segmentos e classes, e uma escola pública tutelada em função de "interesses sociais" oferecerá uma formação de contornos bastante discutíveis, em que se refletirá a desigualdade social, expressa na força e no poder graduais de seus diversos grupos e segmentos, como fator de regulação e determinação do espaço público. É como se a educação escolar só tivesse 
relevância quando favorece aquilo que atende ao interesse estritamente privado, e não o de um mundo público, onde as pessoas possam se relacionar como iguais e nessa condição agir, e não simples e naturalmente se adequar. Talvez não haja forma mais eficaz de se aumentar a desigualdade educacional do que delegar à esfera social a legitimação e orientação da escola pública, ainda que pautada por uma ideal igualdade educacional - em termos de oferta e de serviços educacionais prestados -, o que não necessariamente significa uma formação orientada por valores de um mundo público.

A idéia de uma responsabilidade social ou da "apropriação da escola pela sociedade" defendida por Mello (1988) parece reafirmar a hipótese liberal de uma "harmonia de interesses" - base da economia "clássica" - no âmbito da esfera social. Uma hipótese como essa só pode ter como pressuposto uma espécie de ficção comunística:

\begin{abstract}
Não Karl Marx, mas os próprios economistas liberais foram levados a introduzir a "ficção comunística", isto é, a supor a existência de um único interesse da sociedade como um todo com o qual "uma mão invisível" guia o comportamento dos homens e produz a harmonia de seus interesses conflitantes. A diferença entre Marx e seus percussores foi apenas que ele encarou a realidade do conflito, tal como este se apresentava na sociedade de seu tempo, com a mesma seriedade com que viu a hipotética ficção da harmonia. Esteve certo ao concluir que a "socialização do homem" produziria automaticamente uma harmonia de todos os interesses; e apenas teve mais coragem que os mestres liberais quando propôs estabelecer na realidade a "ficção comunística" subjacente a todas as teorias econômicas (Arendt, 1995, p. 54).
\end{abstract}

No âmbito de uma esfera social, uma suposta "harmonia de interesses" diz respeito à reunião de diversos interesses individuais que, não obstante suas diferenças, comungam do fato de se orientarem por valores ligados à atividade do labor e à busca da melhor condição material de manutenção de suas vidas. A própria competitividade acirrada entre indivíduos e organizações verificada e encorajada pela sociedade de consumo é totalmente coerente com uma suposta "harmonia de interesses". Mas esses interesses não são comuns aos indivíduos e tampouco se orientam por valores públicos, o que não significa que não se "harmonizem" em relação a um dos pilares fundamentais de sustentação da esfera social: a satisfação das necessidades dos indivíduos que a compõem.

Esse "ponto de vista social" não se resume à legitimação do "mercado" como instância norteadora dos negócios públicos. Está presente também em determinadas perspectivas que se pretendem críticas da organização da sociedade - inegavelmente desigual quanto às condições materiais de vida de seus vários segmentos e classes. É o caso de muitas análises que situam a 
compreensão de alguns aspectos da narrativa instrumental da qualidade como simples reflexo de uma sociedade desigual e excludente, consequiência do sistema capitalista e das novas feições que ele adquire para sua manutenção e fortalecimento.

Parece haver nessa narrativa da qualidade instrumental algo que escapa à sua circunscrição apenas a certas orientações políticas atuais - não só em educação - entendidas como um movimento mais amplo e hegemônico, muitas vezes rotulado precariamente como neoliberal ou conservador. Enunciados e repetidos à exaustão, esses rótulos parecem induzir a uma perspectiva única de crítica a essa narrativa, o que talvez seja tão prejudicial quanto os problemas que acarretam sua aceitação e adoção.

Nesse tipo de crítica, convém perguntar pelo sentido atribuído à idéia de escolarização pública como o que se vê, por exemplo, na explicitação dos objetivos do estudo intitulado "O discurso da 'qualidade' como nova retórica conservadora no campo educacional”:

\footnotetext{
Vamos mostrar aqui - basicamente - duas questões. Primeiro, que na América Latina o discurso da qualidade referente ao campo educacional começou a se desenvolver-se em fins da década de 1980, como contraface do discurso da democratização. Segundo, que essa operação foi possível - em parte - devido ao fato de os discursos hegemônicos sobre a qualidade terem assumido o conteúdo que esse conceito tem no campo produtivo, imprimindo aos debates e às propostas políticas do setor um claro sentido mercantil de conseqüências dualizadoras e antidemocráticas. No campo educativo, o discurso da qualidade foi assumindo a fisionomia de uma nova retórica conservadora funcional e coerente com o feroz ataque que hoje sofrem os espaços públicos (democráticos ou potencialmente democráticos), entre eles, a escola das maiorias (Gentili, 1994, p. 115).
}

Nas próprias palavras do autor, questionamos: ao se falar em educação pública, devese considerar uma "escola das maiorias" ou uma escola para todos que tenham direito a ela o que hoje significa a totalidade da população -, de acordo com a própria idéia de uma res publica? Uma escola pública só é legítima se seu trabalho for orientado para o que se poderia chamar de "maiorias"?

É essa equiparação do conceito de público com maioria que compromete os próprios pressupostos da crítica. No esforço de atender aos anseios "das maiorias", a escola revelaria não o caráter público de seu compromisso, mas uma espécie de convergência dos interesses particulares dos diversos indivíduos compreendidos nessas "maiorias", imersos numa sociedade de consumo marcada pela confusão entre o público e o privado.

A própria expressão "escola das maiorias" revela uma visão que não distingue uma esfera pública de uma esfera social. Sem essa distinção, é compreensível que um problema 
público como o da qualidade em educação se transforme num "problema social", e seja analisado e discutido apenas por essa ótica. Há aí o pressuposto de que a educação escolar deve se voltar - principal ou mesmo exclusivamente - para o interesse de grupos particulares, ainda que majoritários - notadamente desfavorecidos, numa sociedade absolutamente seletiva e desigual. Contudo, os termos em que se assenta essa denuncia de uma flagrante desigualdade social não rompe com essa visão instrumental e economicista da educação associada aos interesses típicos de uma esfera subordinada ao labor.

À medida que a qualidade em educação é vinculada aos interesses de determinados segmentos sociais - ou, segundo a categorização de Gentili (p. 174), atrelada aos grupos dos "excluídos" ou "marginais", em oposição aos "incluídos" ou "integrados" -, verifica-se como esses interesses podem, pelo tipo de argumentação feita, ser inusitadamente os mesmos em ambos os grupos $^{34}$. A titulo de conclusão, o autor afirma que:

Um novo discurso da qualidade deve se inserir na democratização radical do direito à educação. Isso supõe que, numa sociedade plenamente democrática, não pode existir contradição entre o acesso à escola e o tipo de serviço por ela proporcionado. Assim como não há democratização sem igualdade de acesso, tampouco haverá sem igualdade na qualidade recebida por todos os cidadãos e sem a abolição definitiva de qualquer tipo de diferenciação ou segmento social. Claro que isso não supõe "baixar o nível de todos". Supõe, pelo contrário, "elevá-lo", transformando a qualidade num direito, e não numa mercadoria vendida ao que fizer melhor oferta (Gentili, 1994, p. 176).

Trata-se, então, de uma qualidade destinada "às maiorias" ou a de uma "qualidade" a ser recebida por todos? Se for esse o caso, devemos requerer que "as maiorias" obtenham o mesmo padrão de qualidade destinado aos "integrados" ou "incluídos”? Afinal, quando o autor afirma, mais adiante, que "não existe 'qualidade' possível quando [...] se nega o direito à cidadania a mais de dois terços da população" (Gentili, 1994, p. 177), está implícito que um terço tem acesso a esse direito e que, para que fossem "incluídos" os outros dois terços, deverse-ia estender a qualidade a toda a população, ao menos do ponto de vista educacional. Será que o significado de "elevar a qualidade" da educação é a necessidade de estendê-la a todos nos mesmos moldes?

\footnotetext{
${ }^{34}$ Para além de seu interesse ou de sua pertinência como categoria de análise, a idéia de "exclusão social" implica não raro a suposição de que é desejável que aqueles que estão em tal situação sejam incluídos, o que significaria o usufruto das mesmas condições dos que são alegadamente privilegiados. É o que transparece na seguinte afirmação: "Consumir mercadorias de qualidade não é um direito de ninguém, nem tem por que ser, nesse tipo de sociedade que se chama de capitalismo. Na terminologia do moderno mercado mundial, 'qualidade' quer dizer 'excelência' e 'excelência', privilégio, nunca direito" (Gentili, 1994, p.173).
} 
A preocupação aí é a de se chegar ao mesmo patamar de qualidade conquistado pelo grupo dos "incluídos". Não se trata apenas do esforço para se elevar a qualidade, mas do reforço de uma concepção de qualidade que vê a educação como um mero "serviço" - termo do próprio autor -, uma instrução presumivelmente capaz de fornecer os elementos para uma melhor inserção na sociedade, e não uma formação ancorada em valores e interesse públicos.

As indagações que levantamos acerca desse tipo de análise e interpretação apontam não uma discussão da qualidade da escola e da educação pública - isto é, seu sentido na constituição e manutenção de um mundo comum e o que ela pode significar para todos os cidadãos, e não apenas para parte deles, por maior que seja -, mas uma crítica à sociedade dividida entre "excluídos" e "incluídos" e, portanto, uma discussão cujo foco e caráter são extrínsecos à escola e a sua vocação como instituição responsável por uma formação pública.

Nesses termos, se hipoteticamente todos os "excluídos" fossem, por assim dizer, admitidos na sociedade em igualdade de condições, não se daria automática ou necessariamente o aumento da esfera pública ou mesmo a caracterização de uma escola plenamente voltada para os valores públicos. Ao contrário, é mais provável que a esfera social saísse mais fortalecida, já que todos teriam mais acesso ao consumo, inclusive de bens culturais. O parâmetro de qualidade em educação permaneceria o mesmo, voltado apenas para os resultados da educação escolar no âmbito social. À medida que o desejo manifesto é a maior inclusão dos indivíduos materialmente desfavorecidos e aviltados em sua capacidade de prover suas necessidades, a questão da qualidade em educação fica restrita aos termos a ela impostos por uma esfera social pautada não por interesse e valores públicos, mas pela satisfação coletiva de interesses individuais. De certo modo, são duas faces da mesma ficção comunística, voltada não para os interesses de uma esfera pública, mas sob os ditames inerentes à esfera social.

Evidentemente, uma sociedade menos desigual é sempre desejável - e provavelmente mais justa -, mas isso não significa que sua esfera pública seja fortalecida e que os homens tenham mais e melhores condições de agir politicamente. Uma formação escolar pública é antes associada à participação em um mundo comum do que um meio de satisfação de necessidades vitais e interesses puramente particulares.

Certas perspectivas de análise - alegadamente críticas, como a que acabamos de ver podem facilmente sucumbir ao ardil de se concentrarem fora dos muros escolares, perdendose uma preciosa oportunidade de se refletir e discutir sobre o que a escola faz e sobre o sentido de sua ação, e não só sobre o que factualmente produz em "termos sociais". O risco da 
banalização de uma crítica do discurso da qualidade com vista a fins estritamente instrumentais e utilitários - e das diversas medidas e iniciativas tomadas em seu nome - como uma "artimanha do neoliberalismo" pode mesmo perder de vista o caráter público da educação escolar e o inerente dever das escolas públicas de justificar e se responsabilizar por suas escolhas e pela organização e práticas que adotam.

De qualquer modo, a reflexão em torno do caráter público da educação como um critério para a definição de sua qualidade conduz a uma questão apenas mencionada, mas que demanda uma abordagem mais detida. A própria idéia de "queda de nível" da qualidade e a sua contraface, a "escola de alto nível", indicam a valorização de uma escolarização completamente independente da esfera pública - ou do que restou dela. Assim, não surpreende a freqüência com que se vê um ideal fortemente arraigado que associa a melhor educação, isto é, a "educação da mais alta qualidade", à iniciativa privada no campo educacional e às escolas particulares.

\subsection{A imagem de excelência da escola particular e o estigma da escola pública}

Numa análise do conceito de qualidade aplicado à educação no Brasil, é praticamente inevitável esbarrar em certo parâmetro do que é uma "boa escola", tão veiculado e tão pouco discutido. Com raras exceções, a tão propalada "boa escola" é a escola particular, em franca oposição à qualidade oferecida, acredita-se, pela escola pública.

Essa concepção, tão generalizada, guarda estreita relação com o processo de estigmatização pelo qual passou a escola pública nas últimas décadas, em função da política de democratização do acesso, em especial a partir da expansão do ensino ginasial em São Paulo em 1967 e, a partir do início dos anos 1970, estendida aos outros Estados do país. De forma similar ao status crescente de que goza hoje a escola particular, a "boa escola" de antigamente - pública - era acessível a apenas uma diminuta parcela da população nas séries mais avançadas, mas:

[...] com a maciça expansão de vagas ocorridas a partir de 1967, a escola sofreu o impacto da presença de uma numerosa clientela nova, que trouxe problemas de ensino até então inéditos. Antes disso, a escola pública vinha desempenhando com relativo êxito a sua função de instituição social discriminadora da população segundo os interesses sociais e políticos prevalecentes (Azanha, 1995, p. 13). 
A concepção de uma "queda na qualidade do ensino" tem caráter abstrato, se levarmos em conta que "a escola de poucos de ontem era e é historicamente diferente da de todos de hoje" (Azanha, 1995, p. 13). Para aquele enorme contingente de alunos cujo direito à escola pública era altamente restrito, não se tratava de ter ou não uma educação considerada de qualidade, mas antes poder freqüentar ou não uma escola. Para esses alunos, a possibilidade de prosseguir os estudos sem dúvida consistia na garantia de uma qualidade até então inexistente. A escola de "antigamente" e a escola pública atual são instituições com papéis notadamente diferentes, com outros alunos, outros professores e outras práticas pedagógicas.

Entretanto, à medida que a escola foi se massificando, no sentido da democratização do acesso, forjou-se a percepção da deterioração da qualidade de ensino ofertada pela escola pública. Além de própria resistência do magistério às mudanças radicais ensejadas pela ampliação de vagas, Azanha aponta outros interesses e motivações "facilmente identificáveis" para a solidificação dessa imagem negativa associada à escola pública:

De um lado, temos o segmento médio da classe média que, com a popularização da escola pública, perdeu um poderoso elemento distintivo de status social. De outro, temos o grupo social constituído de interesses privados e confessionais - quase sempre conjugados nas questões de educação - na exploração comercial ou ideológica do ensino. E, finalmente, temos o próprio magistério público, profissionalmente aturdido e, pela sua própria extração social, identificado com os dois grupos cujos interesses haviam sido contrariados (Azanha, 1995, p. 14).

No vácuo da deterioração da imagem positiva associada à escola pública, sua estigmatização ensejou uma crescente valorização da escola privada, não raro associada à idéia de excelência. Um exemplo dessa inversão é a diferenciação e valorização da escola de elite - privada - frente à escola publico. A propósito de uma discussão de certos objetivos estratégicos para a educação no início dos anos 1990, Mello diz ser necessário:

O devido equacionamento da eqüidade com qualidade, reconhecendo que a desigualdade atualmente já não ocorre tanto entre os que têm acesso à educação e os que dela são excluídos, mas principalmente pela segmentação interna do sistema educacional. A oferta divide-se hoje entre um ensino minoritário de alta qualidade para uma elite e um ensino sem qualidade nenhuma para a grande massa que, embora chegue à escola, não consegue ter suas necessidades de aprendizagens atendidas (1998, p. 64).

É o próprio sentido dessa comparação entre a qualidade de entes diferentes, isto é, escolas públicas e escolas privadas, que pretendemos discutir. O estigma da escola pública 
funciona como uma marca que a rotula, como se essa escola, justamente por ser pública, fosse inerentemente ruim, por oposição à "boa qualidade" associada à imagem da escola particular. É como se qualidade de uma escola pública - ou melhor, uma formação escolar pública prescindisse de maior atenção e reflexão, à medida que o parâmetro de "excelência" em educação está na escola particular e na distinção econômica da elite que a freqüenta. Restaria à escola publica a busca desses padrões situados na esfera social - algo pouco provável de se reproduzir materialmente nos mesmos termos e condições em todas as escolas, mas cujo significado social é amplamente valorizado.

A força dessa noção da "boa qualidade" vinculada à escola particular - e, ultimamente, da própria iniciativa privada no âmbito da educação escolar pública - pode ser ilustrada a partir de dois exemplos que identificam o interesse e o poder com que essa imagem de escola e de seu parâmetro de qualidade vai se sedimentando na sociedade brasileira e na própria condução das políticas públicas mais recentes.

Tem-se visto um movimento inédito de contratação, por parte de sistemas municipais de ensino, de grandes grupos educacionais privados para orientar e pautar esses sistemas públicos não só pela aquisição de materiais didáticos, mas também pela apropriação de metodologias de trabalho docente, formas de gerenciamento e gestão das unidades e dos próprios sistemas escolares ${ }^{35}$. Acredita-se que cerca de 190 municípios brasileiros, entre os quais $25 \%$ dos municípios paulistas, fazem parceria com esse tipo de iniciativa privada, num "promissor mercado educacional"

Destacam-se aqui as iniciativas do grupo Positivo que, com seu Sistema Aprende Brasil de Ensino - Sabe -, atinge 85 mil alunos, em 400 escolas públicas de 11 Estados brasileiros, e o Sistema COC de Ensino e seu Núcleo de Apoio à Municipalização do Ensino - Name. O trabalho desses grupos empresariais tem muitos pontos comuns: produzem e distribuem material didático próprio e oferecem capacitação do professor para o melhor uso desse material, além de manterem portais na internet para atualizações, troca de informações, treinamento e divulgação de ações. Especificamente o Sistema COC visita in loco, a cada

\footnotetext{
${ }^{35}$ Muitos grupos educacionais, detentores de uma rede de escolas particulares próprias ou distribuidores de "pacotes educacionais" a escolas particulares têm procurado, na última década, vender seus produtos e serviços aos sistemas públicos de educação, notadamente os municipais. Dentre esses grupos, destacamos Positivo e COC Sistema de Ensino, de cujos sítios extraímos informações para desenvolver esta argumentação. Disponíveis em <www.positivo.com.br/portugues/educacional/sabe.htm> Último acesso: 12 jul.2007, e $<$ www.sistemacoc.com.br/name/name.asp> Último acesso: 13 jul.2007.

${ }^{36}$ Esses dados são da reportagem da revista Veja, "Escola pública, gestão particular", de 14 fev.2007. Muito sugestivo, esse título é um dos inúmeros exemplos de ampla divulgação e repercussão que opõe a qualidade da escola particular e da iniciativa privada em educação à qualidade da escola pública, como se entes tão diferentes e com demandas tão diferentes pudessem ser avaliados e classificados sob os mesmos critérios, em função do atrativo ideológico inerente ao termo "qualidade".
} 
bimestre, as redes de ensino que o contratam, para acompanhar e avaliar o trabalho realizado em função dos termos acordados na parceria. Sob a alegação de uma "revolução do ensino público", uma das justificativas para a contratação de seus serviços, esse grupo entende que "a parceria com o Sistema COC é uma maneira de democratizar a educação, levando a mesma qualidade de ensino a todas as escolas do município".

E o fato de alguns desses municípios que mantêm parcerias com grupos educacionais privados terem se sobressaído na recente Prova Brasil só reforça o significado da qualidade restrito aos resultados obtidos pela mensuração de determinados aspectos da aprendizagem discente, independentemente de outras dimensões da formação escolar pública. O próprio fato de, segundo o MEC, dos 632 avaliados, sete municípios paulistas terem ficado entre os dez "campeões de ensino" 37 revela o atrativo imperante associado à iniciativa privada na educação básica. Além da conhecida ênfase no parâmetro de qualidade vinculado a determinados resultados de aprendizagem, se poderia perguntar, por exemplo, como se saíram nessa avaliação os demais municípios de São Paulo que adquiriram esses pacotes educacionais ou também verificar em que medida parcerias como essas obteriam os mesmos resultados em municípios mais pobres - admitindo-se a improvável plausibilidade da proposta - do Norte ou Nordeste, com menos tradição na organização e gestão do ensino público e na eliminação das desigualdades verificadas em termos de acesso e fluxo escolar (Oliveira, 2003). A formulação dessas questões parece indicar um forte viés, de caráter ideológico, associado à qualidade do ensino privado em detrimento do ensino público.

Ainda que os reflexos e o melhor detalhamento dos resultados alcançados em conseqüência dessas parcerias possam demandar outros estudos de caráter empírico, é o próprio mérito desse tipo de relação que deve ser analisado e debatido, isto é, a prerrogativa de empresas privadas - presentes num crescente "mercado educacional" - na gestão e orientação do trabalho das escolas públicas. A própria padronização de um projeto pedagógico pautado na eficiência e a inevitável rigidez da orientação e da condução dos trabalhos escolares vinculadas a essas "franquias pedagógicas" mostram a gravidade do problema e seus contornos políticos.

Uma vez adotado um desses pacotes educacionais - cuja marca distintiva é a produção e a aplicação de um mesmo material didático a qualquer rede pública de ensino que se disponha a pagar o preço estipulado -, as unidades escolares, seus professores e equipe

\footnotetext{
${ }^{37}$ Cf. revista Veja, 14 fev.2007.
} 
técnica se vêem na posição de meros executores dessas propostas, orientados por um mesmo padrão de ação pedagógica, pautada pelo uso desse material.

Não seria de estranhar que um professor desses sistemas de ensino que, por motivos estritamente pedagógicos, usasse outros materiais didáticos ou uma proposta metodológica diferente fosse questionado ou mesmo repreendido por instâncias superiores da Secretaria de Educação, ou que fosse cobrado pelos pais de alunos, ansiosos para verem os professores "chegarem até o final do livro didático" e "cumprirem toda a matéria", como se essa fosse a meta exclusiva da escola. É o tipo de situação que poderia concretamente suprimir a "pluralidade de idéias e concepções pedagógicas" prevista na Lei de Diretrizes e Bases da Educação Nacional (Art. 13, inciso III), e na própria Constituição Federal (Art. 205, inciso III).

A relevância desse princípio constitucional se deve "justamente ao fato de que ele é a tradução no nível escolar do próprio fundamento da convivência democrática que é a aceitação das diferenças" (Azanha, 1993), inclusive de natureza pedagógica. Não deixa de ser autoritária e temerária a concepção de que há um método melhor ou de que uma determinada concepção pedagógica é superior a outras, mesmo numa mesma escola. É comum haver divergências entre diferentes noções pedagógicas, mas isso não implica necessariamente que haja concepções melhores que outras numa disputa como essa. Num Estado democrático, eventuais divergências entre noções pedagógicas devem ser até estimuladas, uma vez que são sempre passíveis de questionamento quanto a suas "alegadas fundamentações cientificas" (Azanha, 1987, p. 138).

A autonomia do professor e da própria unidade escolar são pressupostos éticos da tarefa educativa. Assim, uma formação escolar transcende o mero uso de um material didático alegadamente exitoso ou o cumprimento de metas de aprendizagem discente passiveis de mensuração.

Quando se insiste na autonomia da escola como uma das condições de melhoria do ensino, não podemos reduzir essa melhoria a um ensino simplesmente mais eficiente no seu conteúdo estritamente escolar. Para isso não seria preciso reivindicar uma escola autônoma; até mesmo uma escola fortemente presa a regulamentos rígidos e impostos seria capaz de ser uma "boa" escola.

O fundamental é que a autonomia de nossas escolas públicas esteja impregnada de um ideal pedagógico que constitua a base da tarefa educativa, cuja excelência há de ser medida por sua capacidade de instalar uma autêntica convivência democrática e, por isso mesmo, de formar alunos críticos, livres e criativos até mesmo a partir de condições sociais, políticas e econômicas adversas (Azanha, 1995, p. 141). 
Numa formação escolar pública, o critério de adequação de uma determinada concepção pedagógica é sua pertinência e sua coerência com os próprios princípios éticos da tarefa educativa voltada para os valores públicos e um mundo comum. O grau de eficiência de uma determinada concepção pedagógica quanto à aprendizagem dos alunos deve ser levado em conta, mas não pode se converter num critério exclusivo para sua adoção ${ }^{38}$.

Destituída de objetivos e valores públicos ${ }^{39}$ - a serem discutidos e acordados coletivamente por seus agentes institucionais - ou ligada a interesses de ordem privada, como vimos, a própria autonomia da escola pode comprometer o caráter público de sua formação:

A autonomia da escola numa sociedade que se pretenda democrática é, sobretudo, a possibilidade de ter uma compreensão própria das metas da tarefa educativa numa democracia. Sem essa possibilidade, não há como falar em ética do professor ou em ética da escola e, sem isso, a autonomia deixa de ser uma condição de liberdade e pode até ser facilitadora da opressão. Sem liberdade de escolha, professores e escolas são simples executores de ordens e ficam despojados de uma responsabilidade ética pelo trabalho educativo. Nesse caso, professores e escolas seriam meros prestadores de serviço de ensino, de quem se pode exigir e obter eficiência, mas que não respondem eticamente pelos resultados de suas atividades (Azanha, 1993, p. 14).

É nesse sentido que se postula, para cada unidade escolar, a responsabilidade pelo planejamento e pela execução de um projeto pedagógico próprio como um legítimo exercício de autonomia. A presença dessa prerrogativa na LDB (Art. 12, inciso I, e Art. 14, incisos I e II) tão desejada por muitas escolas e professores, converte-se, paradoxalmente, em "um comprometimento total com o ideal democrático de educação" (Azanha, 1993, p. 12).

Voltando aos grupos prestadores de serviço a sistemas públicos de educação, não é casual que tenham muitos traços comuns. A forte expansão dessas empresas educacionais se deu à custa da notoriedade alcançarada a partir da criação de cursinhos preparatórios para o vestibular em suas cidades de origem, como é coso do COC, em Ribeirão Preto, e do grupo Positivo, em Curitiba ${ }^{40}$. Aliás, a própria constituição de exames vestibulares tem favorecido,

\footnotetext{
${ }^{38}$ No Capítulo 3, se analisa e discute a idéia de um ensino eficiente vinculado ao conceito de qualidade e como, tomado exclusivamente, esse critério pode comprometer o caráter de público de uma formação educacional.

39 "O simples fato de que cada escola, no exercício de sua autonomia, elabore e execute seu próprio projeto escolar não elimina o risco de supressão das divergências e nem mesmo a possibilidade de que existam práticas escolares continuamente frustradoras de uma autêntica educação para a cidadania. Na verdade, a autonomia escolar desligada dos pressupostos éticos da tarefa educativa poderá até favorecer a emergência e o reforço de sentimentos e atitudes contrários à convivência democrática.” (Azanha, 1993, p. 14).

${ }^{40} \mathrm{O}$ início como curso pré-vestibular, a posterior ampliação e expansão, a criação de uma rede de escolas próprias e, mais recentemente, de faculdades e até de universidades parece ser uma característica comum entre essas empresas educacionais, a que se poderiam acrescentar outros exemplos, não menos famosos, como os grupos Objetivo (www.objetivo.br) e Pitágoras (www.pitagoras.com.br).
} 
em alguma medida, as bases para a atual vinculação da qualidade em educação ao desempenho em exames e avaliações em larga escala.

Não é de hoje que um dos grandes parâmetros de qualidade em educação - ampla e inegavelmente valorizado socialmente - se refere aos resultados de uma determinada escola na aprovação de seus alunos nos exames vestibulares, ao menos os mais concorridos, notadamente os de universidades públicas.

Há uma visão corrente, em grande medida corroborada por agentes institucionais e ampla parcela da sociedade - inclusive a mídia e um número expressivo de pais de alunos de que uma boa escola é aquela que prepara bem seus alunos para os exames vestibulares. As escolas particulares, isto é, algumas poucas escolas particulares que acabam representantes de seu segmento, forjam assim uma imagem de excelência pelo êxito nesses exames.

Pode ser interessante a discussão do sentido atribuído a essa qualidade a partir de um pequeno exemplário de discursos e informações em torno de uma escola reconhecida pela obtenção desses resultados. Escolhemos essa escola pelo lugar que tem ocupado na mídia, seja por autopromoção ou por meio de reportagens, mas sublinhe-se que esta breve análise visa apenas sinalizar como essa escola materializa um principio que atribui ao processo de escolarização o papel - preferencial e inequivocamente superior a qualquer outro - da necessária ascensão social por parte de seus alunos, como veiculo capaz de favorecer a permanência ou o acesso a uma elite econômica. Trata-se aqui de fins tipicamente orientados pelos interesses e circunstâncias de uma esfera social, e não de uma esfera pública.

Apoiamo-nos, em princípio, nos discursos de um veículo oficial de informação desse colégio e dos valores implícitos. Nesses termos, a análise pode parecer caricatural, e não um retrato fiel da escola. Contudo, como em toda caricatura, destacam-se neste exemplo alguns traços marcantes da referida escola não para ironizar uma dada realidade, mas a fim de pôr em relevo alguns aspectos de uma escola particular notadamente associada a uma excelente qualidade.

Assim, o colégio Bandeirantes ${ }^{41}$, na cidade de São Paulo, parece ser o campeão de aprovações nos vestibulares, com $8 \%$ de seus alunos ingressantes nos cursos mais concorridos

\footnotetext{
${ }^{41}$ Usaremos o discurso do sítio de divulgação desse colégio na internet, cujo último periódico de circulação interna ( $\left.n^{\circ} 56\right)$ reproduz a reportagem, publicada no jornal Folha de S.Paulo, intitulada: "Datafolha confirma: Bandeirantes é o primeiro na USP.” De qualquer forma, não são poucas nesse sítio as referências ao êxito obtido pelos alunos do colégio nos exames vestibulares das universidades públicas mais concorridas (Disponível em <www.colband.com.br> Último acesso: 23 abr.2006). Embora tenhamos optado por esse colégio, dada a riqueza e abrangência das informações disponíveis, poderíamos encontrar semelhanças de proposta, principalmente no que diz respeito à coincidência de objetivos, em outros colégios conhecidos por seus resultados nos vestibulares mais concorridos (Cf. <www.colegioetapa.com.br> e <www.objetivo.br> Último acesso: 27 abr.2008).
} 
da Universidade de São Paulo em 2005. Segundo entrevista de seu diretor-presidente, Mauro Sales de Aguiar, não paira qualquer dúvida sobre o objetivo e norte maior do colégio. Ao ser perguntado sobre o "papel que cabe a uma instituição como o colégio Bandeirantes”, diz:

\begin{abstract}
Nós temos uma missão bastante clara: colocar nossos alunos nas melhores instituições de ensino superior do país. Os números mostram que temos atingido nosso objetivo. Nossos alunos obtêm os mais altos índices de aprovação nos principais vestibulares. Em 2001, por exemplo, obtivemos $15 \%$ das vagas de Medicina na USP, $14 \%$ das cadeiras na Escola Paulista de Medicina, $13 \%$ das vagas de Administração de Empresas da Fundação Getúlio Vargas. Sessenta e três alunos nossos foram aprovados, em 2001, na Escola Politécnica. Uma outra escola, cujos alunos conseguiram o segundo melhor resultado, conseguiu aprovar ali 24 alunos. E o número de candidatos da referida escola era praticamente o mesmo. Respondendo à sua pergunta, nosso papel continuará sendo o mesmo: colocar nossos alunos nas melhores instituições de ensino superior do país ${ }^{42}$.
\end{abstract}

Ainda que em um dos itens do sítio se aluda à missão da instituição de "desenvolver equilibradamente processos educacionais de informação e formação para estimular o exercício da liderança e habilitar o educando a atuar na sociedade com senso crítico, iniciativa, criatividade, independência e responsabilidade social"43, parece evidente que todos os objetivos e valores proclamados e mesmo a missão que venha a ter o colégio estão subordinados e, mais do que isso, condicionados a um trabalho cujo fim é o êxito dos alunos nos exames vestibulares mais concorridos. Na própria estrutura física e organização do colégio $^{44}$, alegadamente parte da qualidade oferecida, identificam-se preocupação e atenção especiais para com o objetivo maior, constatando-se o peso atribuído ao vestibular, a partir do

\footnotetext{
${ }^{42}$ Disponível em <http://cultural.colband.com.br/jornal/not_zoom.asp?idNot=6\&idCat=2> Último acesso: 24 abr.2006.

43 Além dessa missão, na mesma parte do sítio constam dois outros itens. Sua visão é descrita como "ser a melhor organização de ensino do país, capitalizada e rentável, reconhecida como centro de referência no emprego de novas tecnologias e métodos pedagógicos, aplicados à educação", e seus valores seriam a "valorização da educação e do conhecimento; autonomia; capacitação permanente dos profissionais; tradição, pioneirismo e inovação; ética, integridade e honestidade; espírito público e cidadania". Ao que tudo indica, a importância do item relativo a valores, que, em tese, orientariam as práticas escolares, tem um peso secundário ou meramente retórico.

${ }^{44}$ De fato, a estrutura e a organização do colégio são muito diferentes das da ampla maioria das escolas públicas brasileiras: laboratórios bem equipados (química, física, biologia e matemática), sala-ambiente multidisciplinar, salas-ambiente de línguas, biblioteca, ginásio de esportes, rede de computadores de última geração, provedor de internet próprio e uma carga horária de aulas bastante superior à da escola pública (estadual ou municipal), compreendendo um currículo comum (divido em áreas a partir do $2^{\circ}$ ano do ensino médio) e atividades extracurriculares. Há uma alegada "capacitação constante de seu corpo docente", aliada ao trabalho realizado em departamentos de apoio como orientação educacional, orientação profissional, assuntos internacionais - voltados para a administração de intercâmbios para os alunos - e, evidentemente, orientação para o vestibular. Muito rapidamente, apresenta-se uma série de projetos pedagógicos: oficina de eletrônica, oficina de mecatrônica, xadrez, CPG - convivência em processo de grupo -, voltado para a prevenção ao uso de drogas e para a orientação sexual, SEP - Special English Program - e Programa Cidadania.
} 
currículo divido nas áreas de exatas, humanas e biológicas - típicas desses exames - e um departamento próprio dedicado ao tema.

E quanto aos projetos pedagógicos do colégio? Eles também estariam voltados inequivocamente para o êxito no vestibular? Além de suas naturais extensão e complexidade, a questão talvez demande dados empíricos a que, de fato, não temos acesso. Ainda assim, temos alguns indícios interessantes de como se pode dar a execução desses projetos, mesmo porque eles não podem ser abstraídos de uma certa cultura escolar adotada pelo colégio, cujos pressupostos parecem estar suficientemente explícitos. Por mais bem formulados e potencialmente interessantes que sejam tais projetos, não se pode perder de vista que sua execução depende das condições concretas em que se aplicam. Se imaginarmos, por exemplo, uma escola da periferia paulistana aparelhada como o colégio Bandeirantes, não é difícil supor que os resultados e a própria execução desses projetos fossem bastante diferentes, porquanto a cultura institucional que se cria numa escola é determinada pelo tipo de pessoas que dela fazem parte, pela política educacional de que é alvo, pelas práticas e procedimentos exercidos tanto pelos docentes como pelos próprios alunos, pelos valores cultivados e também pelo tipo de discurso que circula ali, cuja importância é sem dúvida diluída na dinâmica do cotidiano escolar e os objetivos concretos pelos quais a escola se pauta (Azanha, 1995, p.72).

A cultura escolar desse colégio é estruturalmente apoiada nos exames vestibulares e em tudo o que a que eles diz respeito, incluídos a necessária competitividade e a conseqüente frustração reiterada, a preocupação de "responder bem às questões" como finalidade principal da escolarização e a permanente comparação entre os alunos, como critério de organização curricular. Veja-se, por exemplo, como são formadas as turmas de alunos novos, resposta a uma das "perguntas mais freqüentes" do sítio:

$5^{\mathrm{a}}$ série do Ensino Fundamental - procura-se agrupar por escola de origem. $6^{\mathrm{a}}, 7^{\mathrm{a}}$ e $8^{\mathrm{a}}$ séries do Ensino Fundamental - os alunos novos dessas séries são agrupados em turmas próprias, para adaptação.

$1^{\text {a }}$ série do Ensino Médio - o agrupamento tem como referência o resultado do vestibulinho ou os resultados acadêmicos, no caso dos alunos que cursaram a $8^{\mathrm{a}}$ série do Ensino Fundamental em escolas conveniadas ${ }^{45}$.

O próprio Boletim Informativo do colégio reproduz uma notícia no mínimo instigante, publicada pelo jornal Folha de S.Paulo, com o sugestivo título "Bandeirantes estimula a

\footnotetext{
${ }^{45}$ Disponível em <http://www.colband.com.br/funcionario/gane/informacoes_gerais/perguntas_mais_frequentes/ assuntos_gerais.php> Último acesso: 26 abr.2006.
} 
hiperconcorrência entre os alunos". Dados seu destaque e o espaço que ocupa no Boletim, a conclusão parece ser integralmente endossado pelo colégio. Vejamos um excerto do artigo:

A escola é a única dentre as que mais conquistaram vagas na elite da USP a admitir abertamente que classifica, rotula e separa os alunos em turmas segundo seu desempenho acadêmico.

Assim, um aluno do curso de biológicas que esteja na $2^{\mathrm{a}}$ série de nível 1 , a que o colégio chama de $2 \mathrm{~B} 1$, poderá se vangloriar de ser um dos mais bem dotados academicamente de toda a escola. Um menino da 2B2 já não será tão bom. Outro, da 2B6, estará no limbo dos menos qualificados. Os jovens alunos referem-se às turmas de modo diferente. Do pessoal da $2 \mathrm{~B} 1$, diz-se que são "nerds", "cdfs", "sem noção". Da classe dos 2B6, que são os "burros", "vagabundos".

A divisão de turmas segundo o critério de excelência acadêmica acontece também em exatas e humanas. Segundo Mauro de Salles Aguiar, diretorpresidente da escola, serve para a cultura dos alunos na hiperconcorrência que eles enfrentarão no vestibular e na vida. "A meritocracia não foi inventada pelo Bandeirantes", lembra. [...] Tem lógica, mas pode ser cruel também. Professores da escola ouvidos pela Folha foram unânimes na defesa do sistema de classificação. Todos lembraram-se, contudo, de um ou dois casos de alunos que mergulharam em depressão ao serem "rebaixados" de classe, depois de um ano difícil. É que a classificação é refeita todos os anos, uma vez apuradas as notas finais dos alunos ${ }^{46}$.

O objetivo de fazer com que os alunos tenham êxito nos exames vestibulares talvez possa justificar a discutível seleção dos alunos em classes mais homogêneas, mas, assim como não se devem abstrair projetos pedagógicos do contexto em que se aplicam, as questões levantadas aqui pertencem a uma dada realidade social que não pode - nem deve - ser desprezada. Mesmo que se admita a legitimidade desse objetivo, ele só é possível numa escola privada, a partir de interesses privados - como a prestação de um serviço -, e nunca será um parâmetro para uma formação escolar pública.

Uma escola particular é escolhida livremente pelos pais, que assumem diante dela, antes de mais nada, uma posição de "consumidores" ou "clientes". Se o produto não lhes agradar, muda-se o fornecedor ou se dirigem queixas a órgãos de defesa do consumidor. E aqui já nos deparamos com um problema: reduzida a esses termos, uma relação entre clientela e escola não deixa de ser preocupante, posto que a escolarização particular não deixa de fazer parte de uma grande prática social pública que é educação escolar. Nesse caso, a educação é reduzida à condição de mercadoria, dependente não do interesse público, mas daquilo que é valorizado na vida privada dos indivíduos.

\footnotetext{
46 Disponível em <http://cultural.colband.com.br/jornal/not_zoom.asp?idNot=6\&idCat=2> Último acesso: 24 abr.2005.A noticia foi pública pelo jornal Folha de S.Paulo em 29/04/2005.
} 
Na qualidade de organização privada, o colégio em questão só é acessível a uma parcela diminuta da população. Esse traço característico - comum a outras poucas instituições particulares de ensino de elite - incide sobre um aspecto fundamental do caráter público da educação, qual seja, a possibilidade da convivência plural entre os alunos e mesmo entre professores. O ambiente escolar do Bandeirantes é marcado por um tom monocórdio, na medida em que sua clientela não se caracteriza pela diferença, mas pela semelhança - seus alunos são parte de um mesmo ethos social, compartilham uma condição de vida semelhante, determinada economicamente e por interesses convergentes.

Aí, a homogeneidade, que também pode existir em escolas públicas, tem um traço distintivo e peculiar: não se trata de um agrupamento contingente ou aleatório. Não cabe a uma escola pública escolher seus alunos, da mesma forma que o acesso a ela não pode ser negado a quem deseja freqüentá-la, ao menos em seu nível obrigatório e, tendencialmente, no ensino médio e na educação infantil. Já nas circunstâncias de uma escola particular, não basta querer freqüentá-la. Da mesma forma, a pluralidade de idéias e concepções pedagógicas, como reza o princípio constitucional, é submetida aos interesses do colégio e de sua clientela: nesses termos, a discussão livre e pública é inviável, em função da própria necessidade de manutenção do emprego docente, cuja remuneração é, provavelmente, bastante alta.

Pode-se alegar que esse colégio tem uma preocupação com a formação para a cidadania, revelada em seu projeto Programa Cidadania, que consiste em diversas ações: a confecção de uma página virtual, a "Cidadão na linha", produzida apenas pelos alunos do $2^{\circ}$ ano médio de humanas, simulação de diversos órgãos da Organização das Nações Unidas (Monu-EM - Modelo das Nações Unidas), voltada para todos os alunos do $1^{\mathrm{o}}$ ano do ensino médio, o projeto Idade Mídia (um curso de pré-jornalismo para o $2^{\circ}$ ano do ensino médio) e o International Communication and Negotiation Simulantions (Icons), que visa "ser uma simulação de um fórum internacional de debates, com estudantes do mundo inteiro, em inglês e on line, coordenado pela universidade de Maryland, nos EUA".

Ainda no Programa Cidadania, existem um "trabalho voluntário em creches e no Instituto da Criança no Hospital das Clínicas" e uma parceria com escolas públicas que teriam, segundo o sítio, "possibilitado aos alunos a realização de fóruns anuais de protagonismo juvenil e exposições itinerantes de fotografia para a reflexão sobre temas relacionados aos adolescentes paulistanos"

\footnotetext{
${ }^{47}$ Segundo o colégio, essa parceria com escolas públicas propõe a composição de "grupos de estudo de química, geografia, inglês e informática, nos quais nossos alunos ministram aulas de reforço escolar aos estudantes das escolas públicas”. Há que se registrar, entretanto, que, segundo as informações disponibilizadas, as atividades
} 
No entanto, as informações sobre esses projetos não esclarecem seus pressupostos ou o tipo de trabalho que desenvolvem. Ainda assim, os indícios de que dispomos parecem suficientes para sustentar que, para além das boas intenções - sem mencionar a possibilidade de ser mero recurso retórico -, a formação de cidadãos é um fim que não se esgota em atividades pontuais de um ou outro projeto pedagógico específico, sobretudo porque os projetos do Programa Cidadania não são acessíveis a todos os alunos, mas só a parte deles, e também porque não integram o currículo oficial, mas dependem da adesão voluntária dos alunos.

O significado de cidadania subjacente às ações do Programa se confunde com ações de voluntariado e caridade - que, embora nobres, são virtudes ligadas à vida privada dos indivíduos - e não tem as característica da participação em mundo publico e comum. É como se o exercício da cidadania dependesse da boa vontade e do desejo individual dos homens, e não de uma esfera pública, meio pelo qual se pode dar a ação política entre iguais.

Seja como for, nem o Programa Cidadania, nem mesmo uma outra disciplina qualquer do currículo que se proponha a trabalhar, por exemplo, o conceito de cidadania e tudo o que a ele se relaciona garantirão automaticamente que o aluno observará e respeitará os valores e as condutas coerentes com a cidadania e a vida democrática. Evidentemente, é fundamental que, na condição de futuros cidadãos, os alunos tomem ciência da Constituição Federal, da Declaração Universal dos Direitos do Homem e do Cidadão e da trajetória da humanidade na conquista desses direitos. Aliás, a primeira condição para o exercício de direitos e o cumprimento de deveres é que estes sejam conhecidos. Mas a formação da cidadania não pode e nem deve se limitar a esses conhecimentos fundamentais, pois, ao contrário do que pensava Platão, nem sempre o conhecimento do que é certo e virtuoso no leva necessariamente a agir bem (Silva, V., 2001).

A idéia de uma formação para a cidadania e dos valores hoje associados a ela direitos humanos e Estado democrático - não se restringe a um conhecimento intelectual, mas consiste também em fazer com que os alunos adquiram hábitos e posturas coerentes com esses objetivos $^{48}$. Assim, tal formação exige que algo seja sempre lembrado e cultivado pela escola

voluntárias, aí incluídas as parcerias com escolas públicas, já se encerraram há pelo menos dois anos: Projeto Recriança (2001-2003), Projeto Pirilampo (2000-2002), Projeto Oldnet, da Cidade Escola Aprendiz, no Lar Golda Meir (1999-2001) e Grupos de Estudo de "adoção" de estudantes das escolas públicas para reforço escolar (1997-2001). Disponível em <http://www.colband.com.br/funcionario/gcid/diferenciais_pedagogicos/ programa_cidadania/trabalho_voluntario.php> Último acesso: 8 mai.2006.

${ }^{48}$ A esse respeito, é particularmente interessante o pensamento de Canivez, para quem o cultivo da autonomia do educando é necessária à consciência crítica do futuro cidadão, bem como certos hábitos e valores que "só serão 
nas diversas disciplinas do currículo, ao longo de todo o processo de escolarização e em na sua própria forma de se organizar e lidar com os alunos. Ao que tudo indica, essa não parece ser uma preocupação patente, ao menos no que podemos depreender do discurso e dos indícios sobre a prática escolar de um colégio como o Bandeirantes.

Ainda que projetos como os do Programa Cidadania incentivem os alunos ao entendimento não só intelectual mas também a um "engajamento social" e "caridoso", por assim dizer, não se pode creditar isso ao principal ideal de formação proposto pelo colégio, sempre lembrado e cultivado, desde a composição das salas até o que, quantitativamente, é valorizado pelo conjunto dos professores no cotidiano escolar e mesmo dos pais dos alunos: o êxito nos exames vestibulares.

Quando se defrontam os tipos de resultados, a estrutura e a organização de escolas públicas com os apresentados pelo Bandeirantes, estes parecem exercer um certo fascínio, o que só reforça a idéia de que se trata de uma escola de "excelente qualidade". Mas, embora a escola pública, em sua extensão, diversidade e demanda atendida, não tenha as mesmas condições ou o dever de conquistar o mesmo que almejam as escolas consideradas "melhores", é interessante perceber que paira na mentalidade de muitos gestores públicos que o êxito em exames vestibulares é um bom parâmetro de boa escola, como relatado em entrevista feita em 2005 com o secretário de Educação do Estado de São Paulo. Ao ser perguntado sobre as cotas de alunos em universidades, Gabriel Chalita revela a seguinte percepção, bastante comum:

Sentimos, pela evolução dos alunos que entram na USP, Unesp, Unicamp, que estamos melhorando. Na Unesp, passamos de $40 \%$ [de alunos de escolas públicas estaduais aprovados nesse vestibular], e não tem cota. E eram $20 \%$. A USP já passou de $30 \%$, e eram $10 \%$. Esses saltos mostram que o ensino médio está melhor. Você tem que estimular as pessoas a desenvolverem seus potenciais. A Unicamp fez um caminho interessante, que dava uma pontuação para os melhores alunos da rede pública. Um meio termo como esse, tudo bem; mas eu sou contra $\operatorname{cotas}^{49}$.

\footnotetext{
legitimamente inculcados nas crianças se forem universais, isto é, se tiverem valor para todo homem e em todo lugar, se se impuserem a todo ser humano" (Canivez, 1991, p. 54 - grifo do original).

49 Deve-se mencionar a posição de Chalita em relação ao vestibular, que, segundo ele "é um absurdo e não deveria existir. Eu tenho dois doutorados e acho que hoje não entraria no vestibular. O caminho para o Brasil é o Enem e outras avaliações. O cursinho dá dicas sobre como entrar no vestibular. O mito do vestibular é muito ruim, para a escola particular também. É lamentável.” Assim, sua percepção de algumas escolas particulares, incluído o Bandeirantes, é mais incompreensível. Ao ser perguntado sobre o que a educação pública teria a "aprender com a rede privada", diz ele: "Acho que uma coisa importante é que, na comparação da rede privada com a rede pública, dizem que a rede privada é melhor. A rede privada tem algumas escolas que são maravilhosas, mas, na comparação mesmo, a rede pública é melhor do que a privada. Se você pegar Bandeirantes, Pueri Domus, Porto Seguro, Vera Cruz, você vai e chega numas 20 escolas; depois, o salto é de defasagem" (grifo nosso). Disponível em <http://www1.folha.uol.com.br/folha/educacao> Último acesso: 24 jun.2005.
} 
Não se trata de um pensamento isolado de gestor de sistema público que, inclusive, parece ter influência ideológica considerável na rede estadual de ensino que dirigiu, pelos diversos livros, palestras e idéias que vem divulgando. Essa percepção de que o êxito no vestibular é indício inequívoco de qualidade em educação pode ser percebido também nos discursos de pais, alunos e muitos professores e gestores de escolas públicas ${ }^{50}$.

Tratando-se da escola pública, a compreensão do problema ganha outros contornos, pois o que dela se espera não pode ser relegado ou reduzido a eventuais interesses de sua clientela, ou melhor, da comunidade por ela atendida. Se assim fosse, poderíamos, no limite, chegar ao absurdo lógico e ético de perguntar aos alunos o que gostariam de aprender, desobrigando a escola de parte essencial de sua tarefa.

Certamente há muitos conteúdos comuns entre o que se procura ensinar na escola e o que se exige nos vestibulares. Contudo, a forma como a escola abordará tais conteúdos e quais seriam seus objetivos com isso demanda uma maior discussão. Uma escola pública não comporta, por exemplo, certas práticas escolares que se usa empregar num processo de escolarização voltado prioritariamente para o vestibular. O que dizer de uma escola que lança mão explicitamente da classificação de seus alunos em turmas mais homogêneas - indo dos "bons alunos" aos "alunos com mais dificuldades" -, ainda que esse procedimento seja bastante comum em sistemas públicos de ensino? O que dizer do tipo de competição que geraria entre os alunos um ensino que visasse sobretudo a esse fim?

Ainda que os exames vestibulares sejam um dado da realidade social ao qual uma escola não pode se furtar, isso não implica tomá-los como meta - não raro exclusiva - a ser atingida pela escola pública. Inclusive, se as escolas públicas de São Paulo, por exemplo, tivessem como meta a aprovação de seus alunos nos vestibulares mais concorridos, estariam inevitavelmente fadadas ao fracasso, já que a oferta de vagas no ensino superior nessas universidades é notadamente menor do que o número de alunos que concluem o ensino médio.

Tendo em conta a estrutura e os critérios em que se baseiam os exames vestibulares, é forçoso concluir pela idéia de exclusão de muitos em benefício da aprovação de poucos, princípio que atinge diretamente o que talvez seja a condição para uma escolarização pública básica: o acesso irrestrito à escola de todo e qualquer aluno e o direito de nela permanecer

\footnotetext{
${ }^{50}$ No XII Simpósio de Administração da Educação, houve um exemplo interessante: o autor relata a trajetória de uma escola pública cujo objetivo maior era o de preparar os alunos para o ingresso na universidade, isto é, para se saírem bem nos exames vestibulares (Porto, 1996).
} 
pelo tempo que for necessário para a formação do futuro cidadão, por meio de práticas que de nenhum modo discriminem o aluno, pelo motivo que seja (Silva, V., 2001).

É fácil supor que um projeto pedagógico norteado por esse fim enfatiza os extensos conteúdos próprios do vestibular, as melhores técnicas para se sair bem em provas desse tipo, enfim, a preocupação de fazer do aluno um ser capaz, por força das circunstâncias, de só lograr êxito nesse tipo de exame. E tampouco é difícil imaginar que certo número de alunos submetidos a um ensino com esse propósito e tivessem qualquer dificuldade de aprendizado ou não dispusessem do tempo ideal para estudar poderiam ser considerados "descartáveis" ou marginalizados, à medida que se veriam longe de atingir o objetivo da escola.

A despeito do indiscutível direito universal e irrestrito à escola - um traço característico da modernidade -, talvez a narrativa utilitária da qualidade educacional e seu programa prático se distanciem cada vez mais do interesse público. O que vale, por assim dizer, são os interesses vigentes na complexa sociedade de massas e a melhor forma de os indivíduos a ela se adaptarem e nela ascenderem "socialmente", segundo o desenvolvimento de suas habilidades e competências. Ainda que essa educação escolar possa, em alguma medida, atender a determinados desejos e eventuais interesses dos indivíduos - proporcionais à posição desigual que ocupam na esfera social -, isso se dá pelo próprio esvaziamento do potencial formativo da escola e da condição de liberdade do indivíduo.

Todavia, como se sabe, uma nação ou um povo não se reduzem à somatória de seus indivíduos. Em que pesem os fins que lhe são imputados - típicos da esfera social - e o quanto possa servir a diferentes propósitos privados, a formação escolar talvez seja a única instituição capaz de ultrapassar a satisfação das necessidades de seus membros, viabilizando um lastro maior e comum a todos eles. É o que se discute a seguir, com base nas palavras de Celso Beisiegel ante o desafio da consolidação de uma legítima escola pública:

[...] como seria possível comparar, com os mesmos instrumentos de medida, a qualidade da escola que atende jovens privilegiados das classes médias e superiores e de uma outra escola que atende jovens desfavorecidos dessa imensa e miserável periferia urbana? Voltando ao ponto de partida deste trabalho, às minhas reflexões sobre as relações entre a expansão da rede de escolas secundárias e a qualidade de ensino, penso que seria perfeitamente cabível colocar uma questão mais geral, a respeito das possibilidades de comparação entre a qualidade de uma escola destinada à ilustração de uma pequena minoria de jovens privilegiados e de uma outra escola, bem diferente, responsável por importante função no processo de_construção de um povo (Beisiegel, 1990, p. 40 - grifos nossos). 


\section{3- A QUALIDADE INESTIMÁVEL: EDUCAÇÃO COMO FORMAÇÃO PÚBLICA}

Se a democratização do acesso à escola é hoje uma condição fundamental para o estabelecimento de uma educação orientada por valores públicos, não é, entretanto, seu único traço distintivo, pois não se trata apenas de verificar aquilo que a escola produz ou a abrangência de seu atendimento a todos os que a ela têm direito, mas também de analisar e discutir o significado e a direção dessa formação escolar, cujo caráter público demanda um parâmetro de qualidade condizente.

Por outro lado, a forte tendência observada no discurso educacional, marcada por uma narrativa instrumental da noção de qualidade, aponta outras ênfases e para elas se voltam exclusivamente as atenções. Assim, chegamos ao ponto em que a análise do conceito de qualidade em educação revela critérios distintos, talvez irreconciliáveis, ainda que sobre o uso do termo paire a impressão de um consenso. A explicitação de seus significados, contudo, revela sentidos radicalmente opostos.

Um argumento muito aceito em favor da narrativa instrumental é o papel central que se costuma atribuir às avaliações em larga escala, isto é, à mensuração de desempenho discente, cujo mérito seria o de destacar um parâmetro de qualidade mais objetivo, contando com a ampla divulgação dos resultados aferidos. De fato, não são poucas as razões para se mensurar o desempenho dos alunos naquilo que, sob qualquer perspectiva, espera-se que uma instituição escolar ensine. No entanto, a relevância que hoje se atribui à avaliação de desempenho reside no entendimento comum de que o que se avalia é a própria qualidade de ensino ou da educação, e é nesses termos que setores governamentais e outros segmentos representativos da sociedade costumam apresentá-la e eventualmente discuti-la.

Contudo, ainda que uma medida de desempenho seja plenamente justificável, ela não se converte em critério exclusivo e tampouco é necessariamente o principal na determinação da qualidade da educação. A própria idéia de uma medida como fundamento das avaliações em larga escala restringe a qualidade que se possa esperar e cobrar de uma instituição escolar a resultados passíveis de mensuração imediata, como se esse fosse o melhor - e não raro o único - parâmetro pelo qual se poderia defini-la.

O que está em questão não é o fato de a avaliação da qualidade em educação compreender a mensuração de resultados de aprendizagem, mas o de tomá-los como único critério. Embora tangível, essa qualidade não pode ser simplesmente medida, como se a linguagem estatística, normalmente utilizada na divulgação dos resultados do desempenho discente, bastasse para dar uma inequívoca imagem de precisão. Assim, a questão 
fundamental não diz respeito ao quanto, mas ao que se está fazendo e o que se quer fazer, isto é, à própria definição de qualidade de uma educação escolar autenticamente pública.

É de extrema importância que se distingam medir e avaliar - como se faz na discussão acadêmica em torno do assunto nos Estados Unidos, desde meados do século XX -, a partir do conceito de "instrumentos de medida":

A diferença apontada consiste no fato de que na operação da medida a utilização de instrumentos automatiza as distinções ou ajuizamentos quantitativos feitos pelo observador, ao passo que, na ausência de instrumentos de medida, esses ajuizamentos e distinções somente são possíveis a partir da experiência e do tirocínio do próprio observador. [...] $\mathrm{Na}$ avaliação educacional, as situações são semelhantes àquela do observador sem instrumentos. Provas e trabalhos escolares não são instrumentos de medida no sentido canônico da expressão, mas simples meios auxiliares que subsidiam a avaliação pessoal que o professor faz da aprendizagem de seus alunos após um período de ensino (Azanha, 2006, p. 142).

Essa distinção entre as noções de mensuração e de avaliação não é nada trivial, no que concerne à definição da qualidade da educação pública. Nas avaliações em larga escala, alegase um crescente equacionamento das questões de validade e precisão, o que significa que seus instrumentos de medida seriam capazes de fornecer "descrições quantitativas de propriedades" (Azanha, 2006, p. 142). Ainda que essas informações acerca do desenvolvimento e da precisão das avaliações em larga escala sejam potencialmente interessantes, são demasiadamente técnicas para se configurar em objeto de estudo deste trabalho, e isso não se deve à nossa recusa em discutir a metodologia supostamente científica associada às avaliações sistêmicas - aliás, quase inacessível à esmagadora maioria dos interessados em educação pública - mas à nossa convicção de que ela não é absolutamente um critério inequívoco ou necessário para a definição do que é ou deva ser qualidade em educação.

Não é aumentando o grau da lente com que se observa - como parece indicar o constante aperfeiçoamento dos sistemas de avaliação - que se detectarão melhor as causas de uma qualidade ruim ou de sua alegada "queda", mas sim a busca do melhor horizonte em que se deve concentrar o olhar do observador. A foto em close de uma flor pode nos dar uma boa idéia de sua constituição biológica, de sua pigmentação e mesmo de sua beleza, mas nada nos diz sobre o lugar em que se encontra, se há outras flores em volta, se são iguais ou de outro tipo, se foi cultivada ou se a paisagem a que pertence nos agrada ou não, sem contar o fato de que, sob condições especiais, flores podem crescer em paisagens áridas. Nessa analogia, é 
como se a discussão e a definição da qualidade avaliasse apenas algumas flores, em completa abstração do tamanho e riqueza dos horizontes de que fazem parte.

Pode a qualidade em educação ser estimada apenas pela medição dos resultados que os alunos obtêm em grandes sistemas de avaliação de desempenho? Uma definição restrita como essa - pressuposto da narrativa instrumental que a engendra - pode compreender uma formação voltada para a esfera pública, para um mundo comum?

Essas perguntas não admitem respostas de caráter técnico ou metodológico, pretensamente inspiradas em teorias científicas, como se delas dependesse a possibilidade de uma melhoria das situações e problemas normalmente vividos nos sistemas escolares brasileiros. Antes apontam um tema de interesse eminentemente público, e não restrito a comunidades de especialistas ou profissionais do ensino, isto é, trata-se de uma questão política por definição ${ }^{51}$. É o caráter político inerente à questão que enseja uma definição de qualidade capaz de contemplar e relevar o sentido da ação escolar, ao invés de restringi-la a alguns de seus resultados.

\subsection{Qualidade de ensino ou qualidade da educação?}

Nesta discussão, o conceito de qualidade apresenta uma nuance interessante, tanto quanto inevitável, que diz respeito ao uso indiscriminado das expressões "qualidade da educação" e "qualidade de ensino", pois tomar ensino como equivalente de educação pode implicar uma visão distorcida, diluindo as especificidades do ato de ensinar em relação a uma educação escolar, por exemplo. No entanto, o recurso indiscriminado a ambas as expressões não é algo que possa ser simplesmente negado, mas antes constatado.

Esse uso indistinto não é, de forma alguma, incomum, tanto no senso comum como no próprio discurso pedagógico de caráter mais teórico. Whinch, em seu pequeno guia intitulado "Conceitos- chave em Filosofia da educação", localiza alguns trabalhos da filosofia americana que lançam mão do termo "ensino" de forma equivalente ao de "Educação" (1999, p.70).

\footnotetext{
${ }^{51}$ E esse é o mesmo pressuposto da análise dos PCN empreendida por Azanha (2001), por terem sido dos principais subsídios para a formulação das Matrizes Curriculares Nacionais (1997), que orientam o Saeb e Prova Brasil: "O problema das diretrizes nacionais de um currículo de ensino fundamental não é uma questão estritamente científica, mas sobretudo de acuidade cultural para os valores relevantes na formação da cidadania brasileira. [...] Teorias sobre como os alunos aprendem e sobre como se deve ensinar podem até ser importantes em momentos específicos, mas seria um equívoco tomá-las como ponto de partida para propor soluções sobre a questão das diretrizes curriculares nacionais. Fazer isso é optar por uma visão tecnocrática da questão do ensino fundamental e da formação de professores. Diretrizes curriculares são matéria de adesão a valores, e não teorias cientificas" (p. 26).
} 
No Brasil, são inúmeros os casos em que esse uso comum é freqüente. O Instituto Nacional de Estudos e Pesquisas Educacionais - Inep -, por exemplo, responsável pelas avaliações em larga escala de caráter nacional, já utilizou ambas as expressões como se fossem praticamente sinônimas. No último relatório impresso do Saeb (Brasil, 2001) se diz que este sistema "constitui-se em relevante instrumento para subsidiar e induzir políticas orientadas para a melhoria da qualidade da educação brasileira". Em seguida afirma-se que o exame "avalia a qualidade [...] do ensino e da aprendizagem no âmbito do ensino fundamental e médio". Tais expressões não parecem apontar significados claramente distintos quanto ao que querem dizer, mas antes diferenças de natureza retórica. Contudo, se qualidade de educação, nestes termos, devesse ser entendida como algo mais amplo do que "qualidade de ensino" o próprio Inep utilizaria outro título para o documento "Qualidade da Educação: uma nova leitura do desempenho dos estudantes da $3^{\circ}$ série do Ensino Médio" ${ }^{\text {"52 }}$ uma vez que esse estudo, de caráter restrito, utilizou apenas a "avaliação da qualidade de ensino" feita pela Saeb e não da educação, em sentido amplo, que o mesmo sistema se propõe a melhorar.

A própria legislação brasileira estipula que a Educação Básica compreende as etapas de Educação Infantil, Ensino Fundamental e Médio. Ainda que a expressão Educação Básica inclua outras modalidades do sistema escolar brasileiro, não soaria de todo estranho que se dissesse Educação Fundamental ou Ensino Infantil: nenhuma das duas expressões mudaria o que se quer dizer sobre esses níveis de ensino. $\mathrm{Na}$ verdade, em muitos casos a troca de “ensino" por "educação", quando vinculadas ao termo "qualidade", não afetaria o que é dito.

Se o uso indistinto dessas expressões é comum, não é impertinente a distinção entre educação e ensino. A análise de determinados aspectos compreendidos por esses dois conceitos pode elucidar certas circunstâncias e mesmo eventuais problemas de seus usos, como o de considerar que um ensino de qualidade seja inequivocamente o mesmo que um "ensino eficiente" ou o de que a educação escolar de qualidade signifique a simples reunião de atividades que resultem em "aprendizagens eficientes" ou - numa formulação mais suave "aprendizagens significativas".

Comecemos com ensino, cujo uso, assim como o de uma infinidade de outras palavras, não tem limites claramente definidos. Embora facilmente identificável, essa informação não é trivial, à medida que, dependendo do contexto e do propósito, "ensino" adquire significados diferentes.

\footnotetext{
${ }^{52}$ Disponível em <www.inep.gov.br> Último acesso: 4 abr.2006.
} 
Ensinar pode ser a descrição de uma atividade profissional: "ensino, todas as tardes, no $1^{\text {o }}$ ano de uma escola municipal". Aí, termo é muito próximo de educação: "trabalho na área da educação, leciono no $1^{\circ}$ ano de uma escola municipal". No entanto, a análise do ato de ensinar parece requerer uma maior precisão. O professor que "ensina" todas as tardes num $1^{\circ}$ ano também participa, junto com outros professores, do intervalo e de reuniões pedagógicas, fecha e abre portas, corrige provas, prepara aulas, aparta brigas. Atividades como essas, embora façam parte, em sentido amplo, do emprendimento ou ramo profissional denominado ensino, não caracterizam nem o trabalho realizado em uma escola, tampouco o que nela faz um professor (Hirst, 1973). A participação em reuniões e o desfrute de merecidos momentos de descanso nos intervalos são fundamentais para o desempenho profissional do professor, mas, se ele se empenhar apenas nelas, estará longe de ser considerado um bom profissional. Da mesma forma, não será exagero afirmar que, embora a negligência, o absenteísmo ou a falta de planejamento não sejam atividades canonicamente associadas ao ensino, elas podem se converter numa espécie de "objeto de aprendizagem" dos alunos. Bons exemplos dados por professores e escolas se constituem em formas de ensino interessantes - em muitos casos, fundamentais -, e nada impede que sua contraface - os maus exemplos - seja apreendida e cultivada pelos alunos, ainda que não tenha sido essa a intenção da instituição escolar ou mesmo do professor relapso.

Convém distinguir aqui dois tipos fundamentais de uso do verbo ensinar. A depender do contexto, essa atividade pode indicar êxito necessário - "os alunos da professora Roberta aprenderam tudo o que lhes foi ensinado" - ou não - o verbo ensinar pode significar uma tentativa que, não obstante se oriente por uma meta a atingir, não se concretiza necessariamente (Sheffler, 1974). É esse o caso de afirmações comuns como: “o professor de matemática se esforça muito para ensinar seus alunos, mas o fato é que eles aprendem pouco.” Segundo John Passmore (1984):

\footnotetext{
Alguma confusão provavelmente poderá surgir do fato de que todos nós, em algumas ocasiões, usamos a palavra "ensinar" de modo tal que qualquer tentativa de fazer com que alguém aprenda tem o sentido de ensinar e, em outras, ocasiões, somente quando se tem êxito em conseguir que alguém aprenda podemos legitimamente usar a palavra "ensino". Contudo, não sei de nenhuma confusão pedagógica importante a qual tenha, de fato, essa ambigüidade de origem. Comumente, ou o contexto torna claro o significado, ou a ambigüidade não tem consequiência, pois nada se apóia nela (p. 28).
}

De qualquer forma, nem o ensino tomado como uma atividade exitosa, nem como uma tentativa de se alcançar uma determinada meta especificam o tipo de ação a que se referem e 
tampouco o modo como são realizadas. Atividades como apresentar, demonstrar, contar histórias, ficar em silêncio, gesticular, fazer e responder perguntas e seguramente muitas outras podem ser consideradas entretenimento, diversão, passatempo ou ensino, conforme o contexto em que se executam.

Sobre uma sala de aula onde os alunos se sentem aleatoriamente, sozinhos ou com outros colegas, onde muitos falem ao mesmo tempo e estejam envolvidos em diferentes afazeres, pode-se levantar a hipótese, bastante plausível, de que se trata de uma grande bagunça ou de uma típica demonstração de "indisciplina discente". Mas talvez não seja nada disso. O professor pode ter proposto um exercício que demande tanto atividades individuais como em grupo - exigindo dos alunos que se comuniquem uns com os outros. Ademais, a atividade pode ter sido suficientemente instigante para uma participação mais entusiasmada e barulhenta dos alunos. Assim, o que define se uma atividade é ou não ensino são seus objetivos, cujos propósitos são o de produzir aprendizagens de forma intencional (Hirst, 1973) e o tipo de contexto em que se inserem.

Naturalmente, numa instituição escolar, é de esperar que a maior parte das atividades executadas por seus agentes institucionais seja caracterizada como ensino, ao passo que, exercidas fora da escola, atividades semelhantes podem adquirir outra conotação. Numa escola, supõe-se que o ensino não seja aleatório como informar o nome de alguma rua a alguém perdido em busca de orientação: trata-se de uma atividade exercida profissionalmente, numa instituição com características peculiares. É nesse sentido que os propósitos e objetivos do ensino são determinados pelo contexto em que são formulados e veiculados ${ }^{53}$.

O ensino escolar não implica a definição de uma meta exclusiva e tampouco uma ou mais metas se configuram objetivos necessários, à medida que se tenha realizado algum ensino de forma específica e bem delimitada. O próprio uso do verbo indica tais nuances quando se distinguem, a depender do contexto, períodos distintos dessa atividade. Há períodos de ensino relativamente curtos, como o de 50 minutos - padrão de duração de uma hora-aula em muitas redes públicas do país - ou períodos mais longos como três semanas ou três anos.

\footnotetext{
53 A esse respeito, é particularmente interessante a análise de Passmore (1984): "De nenhuma maneira é certo que qualquer um possa ter como profissão ser professor - sua capacidade para ensinar, seus conhecimentos, sua paciência podem ser demasiadamente limitados para que tal opção seja possível - ou ainda que qualquer um possa ensinar crianças disléxicas a ler, ou dar aulas de física quântica ou matemática avançada. Precisamente por isso, temos, hoje, uma classe de professores profissionais, sujeitos a uma preparação especial, ou ainda pessoas a que se incentiva no sentido de adquirir um grau especial de conhecimento em matérias específicas. [...] Devemos, portanto, diferenciar com muito cuidado as duas proposições seguintes 'todos podem ensinar algo a alguém ' e 'todos podem ensinar qualquer coisa a qualquer pessoa'. Temos escolas e tornamos obrigatória a frequiência a elas, porque a segunda proposição é falsa; exageramos as virtudes e a necessidade das escolas porque não reconhecemos o caráter verdadeiro da primeira." Neste trabalho, nos referiremos ao ensino apenas como aquela atividade fundamental e característica da instituição escolar.
} 
Assim, a meta de uma atividade de ensino "pode se encontrar além dos limites da própria atividade ou de um dos segmentos dessa, ou então carecer totalmente de condições temporais" (Sheffler, 1974, p. 77).

Embora muitas atividades de ensino possam, dentre suas diversas e possíveis metas, fazer com que os alunos aprendam, por exemplo, a ser cidadãos, dificilmente se poderia afirmar que isso se aprende apenas a partir de uma aula sobre a "origem grega da cidadania" ou a respeito dos "três poderes da República". Atividades delimitadas como essas - que, segundo Sheffler (1974), se poderiam chamar "lições" - têm, evidentemente, metas específicas como, por exemplo, a aprendizagem de determinadas informações históricas ou o mote para discussão e análise das relações que se podem estabelecer entre os conceitos antigo e moderno de cidadania. Entretanto, outros objetivos e metas dessas lições podem ser mais abrangentes e gerais, demandando sua sucessão e aprofundamento em diferentes períodos de ensino. Analogamente, diferentes tipos de lição e períodos de ensino podem atender a um mesmo objetivo de caráter amplo, como é o caso da formação da cidadania.

Pode-se perguntar qual o tipo de ensino mais exitoso ou talvez, segundo alguns, de "mais qualidade", e qual está mais "fadado ao fracasso"? É uma questão instigante, mas que pode se revelar infrutífera, pois a pergunta pressupõe a existência de métodos de ensino infalíveis, que, independentemente de quem os aplique ou do que se pretenda ensinar, garantam êxito. A sucessão, na ordem do dia, de várias metodologias de ensino que indicam como se deve ensinar e "o que deve ser feito" e as frequientes e justificadas queixas de muitos professores que atestam que "na prática, a teoria é outra" parecem confirmar uma espécie de ilusão metodológica.

A decisão e, não raro, o entusiasmo pela adoção de uma determinada metodologia de ensino comporta a idéia de que ele pode ser orientada por regras cuja estrita observância garante êxito. Não é outro o motivo da frequiência com que se assiste à veiculação de regras de ensino alegadamente derivadas de algum ramo da ciência como a psicologia, por exemplo, sob a alegação de que sua suposta eficácia é respaldada em autoridade científica. Mas regras que visem à obtenção de êxito podem ser mais ou menos pertinentes e interessantes. Orientar os professores para que exerçam um ensino "atraente para os alunos" ou para que partam dos "interesses e da realidade dos alunos" parece tão útil quanto recomendar a uma equipe de futebol que, para vencer a partida, marque mais gols do que o time adversário.

A esse respeito, Scheffler (1974) propõe uma distinção interessante entre regras exaustivas e inexaustivas. Como o próprio nome indica, as primeiras, quando aplicadas, garantem o êxito; é exemplo um manual de um aparelho que, seguido à risca, garante seu 
funcionamento. Já o ensino demandaria a aplicação de regras inexaustivas ${ }^{54}$, cuja aplicação, mesmo atenta e cuidadosa, não garante necessariamente êxito.

Não se pode eliminar a possibilidade de fracasso ao ensinar, entendido como a não obtenção de êxito diante de uma determinada meta, mas o ensino pode ter uma ou mais metas, e certamente muitas delas não podem ser estimadas por qualquer instrumento de avaliação do desempenho discente. Metas de caráter mais amplo e valorativo não se prestam a medição e determinação precisas: trata-se antes de objetos de avaliação e deliberação em função do significado atribuído à educação.

A própria pressuposição de que os resultados de aprendizagem aferidos pelo desempenho dos alunos atestam a "qualidade de ensino" não faz justiça aos diversos usos do conceito e à característica lógica aparentemente comum a muitos deles. Como diz Passmore (1984), ensinar pressupõe uma relação triádica em que, "para todo X, se X ensina, deve haver alguém que ensina e a algo a ensinar" ${ }^{, 55}$ e também a inter-relação entre esses três elementos, ainda que o uso do conceito de ensino nem sempre explicite os termos dessa relação.

Ninguém pode ensinar sem que isso se destine a alguém - que, a despeito das abstrações típicas de muitas metodologias de ensino, são pessoas reais imersas em condições específicas e peculiares, historicamente determinadas - e tampouco pode haver ensino sem que haja algo a ser ensinado. A obviedade dessa observação é da mais alta relevância quando se supõe que é possível determinar a qualidade do ensino ministrado a partir do que os alunos demonstram saber. É possível que os alunos aprendam muitas coisas sozinhos, uma vez que sempre se pode aprender algo sem que ninguém o tenha ensinado. Talvez o ensino tenha ocorrido em condições discutíveis como práticas desrespeitosas à pessoa humana, que de forma alguma são captadas pelos exames, ou a atuação do professor de uma determinada sala tenha sido praticamente nula, caracterizada pela completa ausência de planejamento e responsabilidade, além de um grande número de faltas. Da prática de um professor como esse

\footnotetext{
${ }^{54} \mathrm{O}$ autor ilustra esse tipo de regra com uma analogia bastante sugestiva: “As regras para caçar leões dizem (poderíamos imaginá-lo) aos caçadores como caçar leões. Tais regras incluem os detalhes de treinamento, de preparação da caçada e de como deverá ser ela conduzida. Poder-se-ia supor que um dos conjuntos que compõem tais regras relativas à caçada seria este: "Aponte a sua arma carregada para o leão, em seguida, quando a distância e outras condições forem adequadas, puxe o gatilho." Suponhamos que sejam excelentes o conhecimento e a perícia do caçador, que ele interprete corretamente a adequação das condições e que siga ao pé da letra esse conjunto de regras, assim como os demais conjuntos componentes. Mesmo assim, não fica garantido que algum leão será capturado; o leão pode saltar para longe exatamente no momento crucial" (Scheffler, 1974, p. 86).

55 A verificação de uma relação triádica pressuposta no uso do verbo ensinar não implica uma definição "essencial" de ensino ou a determinação de seu "significado real": "Contando que tal definição seja congruente como alguns modos principais de empregar a palavra ensino', não importará que existam expressões ou variantes idiomáticas às quais não se aplicam. Se inevitavelmente a definição será em algum grau mais estipulativa do que descritiva em sua relação com a linguagem cotidiana, isso é uma característica de todas as definições úteis e não reduz sua utilidade" (Passmore, 1984, p. 26).
} 
- que, infelizmente, está longe de ser uma simples caricatura -, será mais adequado falarmos não em "qualidade de ensino", mas em sua completa ausência. Seja como for, esses aspectos escapam a uma análise dos resultados obtidos.

Determinar a qualidade do ensino por apenas parte de seus resultados na aprendizagem implica desconsiderar uma série de outras dimensões e nuances dessa atividade típica da prática escolar, reduzindo-a a um único aspecto. Nesses termos, uma avaliação da qualidade se converte em simples questão de eficiência, quando se supõe que uma determinada meta daquilo que se espera que tenha sido ensinado pode fornecer um índice de proficiência capaz de atestar o êxito ou o fracasso. Tudo o mais que se poderia esperar de uma instituição escolar fica relegado a um segundo plano ou se perde de vista ${ }^{56}$. É como tentar equilibrar um tripé sobre apenas uma de suas pernas: além de ser muito difícil, é improvável que sua sustentação dure mais do que alguns instantes.

É pelo viés exclusivo da eficiência em termos dos resultados obtidos pelos alunos nos exames que se argumenta e atesta, por exemplo, a superioridade do conjunto de escolas particulares - um grupo que não é absolutamente homogêneo ${ }^{57}$. Contudo, "a escola privada" não é, por definição, acessível a todos - sua organização está sujeita aos interesses de seus mantenedores, suas práticas podem justificar, em atenção à clientela, a discriminação e a segregação de alunos por seu desempenho, pode não haver discussão do planejamento pedagógico, devendo o professor se limitar a seguir o material adotado, não há uma convivência plural de alunos num ambiente autenticamente público e tampouco a discussão pública e livre de determinados pressupostos e medidas adotadas pela escola que eventualmente desautorizem suas instâncias superiores ou contrariem o interesse de algum

\footnotetext{
${ }^{56}$ É o que afirma, por exemplo, Heraldo Vianna (2000) a propósito da mensuração da qualidade em educação: "como conceituar qualidade em educação? Será possível uma definição operacional de qualidade em educação, a fim de mensurá-la com adequação? O problema precisa ser analisado e discutido com a participação da comunidade educacional e de elementos da sociedade. A medida da qualidade em educação, entretanto, não pode ficar restrita apenas ao desempenho escolar. Necessita, também, verificar outras variáveis que se associam e condicionam o rendimento escolar. O que as crianças fazem na escola, o que os professores procuram transmitir aos seus alunos e o que os livros didáticos apresentam refletem expectativas culturais e educacionais da sociedade, bem como seus valores e seus objetivos sociais e econômicos. Assim, é imperativo verificar em que medida a interação dessas variáveis contribui para a qualidade da educação" (Vianna, 2000, p. 189-190). Ainda que não compartilhemos com o autor suas expectativas econômicas da sociedade no que diz respeito à orientação do trabalho escolar, suas palavras - e também as entrelinhas - indicam algo da maior importância: a redução do que se entende por qualidade a apenas um de seus elementos, dentre os muitos que seguramente se poderiam considerar para compor uma "educação de qualidade".

57 A propósito de um debate sobre "Avaliação em educação: o que a escola pode fazer para melhorar seus resultados”, Menezes (2007), ao analisar o efeito-escola e os resultados educacionais de avaliações em larga escala, afirma ser "importante comparar escolas públicas e privadas. A gente sabe que as escolas privadas no Brasil são melhores que do que as públicas. Em média, os alunos da escola privada no Brasil têm um desempenho $20 \%$ superior aos alunos da escola pública. Mesmo descontando todos os efeitos familiares, de livros em casa, computador, automóveis, educação dos pais, tudo. E isso eu atribuo à gestão mais eficiente na escola privada do que na escola pública" (2007, p. 28).
} 
cliente em especial. Nessas condições, são prestadoras de serviço de quem se pode cobrar eficiência, mas nada além disso.

Desse modo, a qualidade do ensino estimada apenas pelo viés da eficiência aponta a adoção de critérios que não têm qualquer compromisso de ordem ética, pois o critério da "eficiência" não implica que o ensino seja bom ou mal, valoroso ou indesejável. Como disse Hirst:

$\mathrm{O}$ ensino exitoso seria aquele que produz de fato a aprendizagem daquilo que se pretende ensinar. O bom ensino, por outro lado, é bem mais difícil de definir. Não estou certo de que o ensino com êxito seja um bom critério para o bom ensino. Na verdade, não há contradição em dizer que uma pessoa foi ensinada com sucesso, mas mal ensinada (Hirst, 1973, p. 177).

Certamente é desejável que a atividade de ensino seja eficiente na consecução de algumas metas estabelecidas, isto é, que obtenha êxito, mas a eficiência tomada exclusivamente pode comprometer ou se contrapor a outros objetivos educacionais tão valiosos quanto a aquisição de certas capacidades e conhecimentos adquiridos por meio do ensino. A partir deste ponto, talvez possamos distinguir mais claramente uma simples prestação de serviço instrucional de um processo de formação voltado para um mundo comum.

A própria vocação da instituição escolar e o trabalho que comumente a caracteriza parecem atribuir um valor ao ensino que ultrapassa muito o critério da eficiência. É o que se depreende da seguinte definição de ensino:

\begin{abstract}
O ensino poderá, certamente, proceder mediante vários métodos, mas algumas maneiras de levar as pessoas a fazerem determinadas coisas estão excluídas do âmbito padrão do termo "ensino". Ensinar, no seu sentido padrão, significa submeter-se, pelo menos em alguns pontos, à compreensão e ao juízo independente do aluno, à sua exigência de razões e ao seu senso a respeito daquilo que constitui uma explicação adequada. Ensinar alguém que as coisas são deste ou daquele modo não significa meramente tentar fazer com que ele o creia; o engano, por exemplo, não constitui um método ou modo de ensino. Ensinar envolve, além disso, que, se tentarmos fazer com que o estudante acredite que as coisas são deste ou daquele modo, tentemos ao mesmo tempo, fazer com que ele o creia, por razões que, dentro dos limites da sua capacidade de apreensão, são nossas razões (Scheffler, 1974, p. 70).
\end{abstract}

Para além de uma descrição plausível do significado do termo, há nessa definição um programa de ações. Esse caráter programático vinculado ao ensino não se resume à eficiência com que determinadas metas são ou não atingidas, mas perpassa os próprios significados que 
se veiculam nessa atividade e sua justificação a partir da forma como é realizada. A doutrinação, por exemplo, está excluída do que se entende por ensino numa escola, ainda que possa produzir certos resultados valiosos para a sociedade de consumo.

Aqui parece haver um traço comum entre ensinar e o conceito mais abrangente de educação: o ensino - como atividade característica da educação escolar - não pode abstrair a relação entre os agentes institucionais da escola e os alunos, pautada pelo esforço de manter e fazer perdurar um mundo compartilhado de valores e razões humanas, cujo caráter público identifica como "nossas razões".

Tais razões - a despeito de toda e qualquer utilidade que uma escolarização possa oferecer à esfera social e à vida privada dos indivíduos - constitui um fim em si mesmo, ainda que esse traço esteja relegado ao esquecimento em favor de um caráter instrumental cada vez mais impingido à escola.

\subsection{Fins extrínsecos à educação e a vocação escolar}

As práticas e disciplinas curriculares, a postura e o discurso dos professores, a pluralidade de visões que comporta uma instituição pública, assim como a própria possibilidade da convivência plural de indivíduos num contexto educacional são aspectos característicos da escolarização - e, sem prejuízo de entendimento, de uma "cultura escolar" (Azanha, 1995) - que podem ampliar a compreensão de algumas das razões que movem e orientam a instituição escolar em sua atividade perante o mundo. Evidentemente, fatores como esses não implicam um atestado de autenticidade ou valor inerentemente positivo, mas são antes categorias de análise.

A cultura escolar de um determinado contexto pode, por exemplo, ser altamente seletiva e discriminatória em suas práticas, privando algum contingente de alunos da conclusão gradual das etapas do ensino fundamental obrigatório, por meio da reprovação uma característica comum em muitas redes de ensino brasileiras. Por outro lado, a negligência da discussão por parte de um corpo docente e dos demais agentes institucionais da escola não favorece o exercício da autonomia escolar e tampouco seu caráter público. A ausência de discussão no âmbito de um trabalho docente coletivo - do que a escola pensa e faz e do que poderia pensar e fazer - pode revelar uma espécie de orientação e apropriação privada da 
instituição escolar, sobrepondo-se os desejos e interesses particulares de seus profissionais ao que é de interesse público.

De todo modo, as diferentes funções ou a utilidade que se pode atribuir à escola não lhe subtraem o que peculiarmente caracteriza sua cultura, seus contornos institucionais e mais propriamente seus "fins intrínsecos" (Peters, 1979). Independentemente do que resulte para a sociedade ou para a vida dos indivíduos, a educação escolar tem algo que lhe é próprio e característico. Sua explicação e determinação vão além da análise e da verificação da objetividade de resultados como o êxito em vestibulares, o desempenho discente em avaliações de larga escala ou mesmo os obtidos nas provas ordinárias das diversas disciplinas curriculares.

É claro que a educação escolar e seus eventuais produtos e resultados podem ser analisados sob muitos ângulos, o que, aliás, é freqüente. Um sociólogo pode atribuir à escola um papel fundamental para o processo de socialização dos indivíduos, um economista pode afirmar que os países considerados desenvolvidos investiram no passado e continuam investindo maciçamente em educação básica e alguém pode até entender que a função da escola é "domesticar as massas" e reproduzir fidedignamente a sociedade estratificada e materialmente desigual que aí está.

De fato, essas concepções quanto aos fins da educação têm diferenças entre si, muito embora não sejam necessariamente antagônicas. Mais ainda, elas têm em comum o fato de serem fins extrínsecos às instituições escolares, distintos de objetivos próprios da vocação de uma escola ou de uma área de estudos em educação que tenha como objeto o sentido da ação escolar, sua história e seu cotidiano.

Os diversos ângulos sob os quais se pode descrever e analisar a educação tangem limites determinados pelo próprio objeto - no caso, a instituição escolar e o tipo de trabalho nela realizado, sob condições específicas. Uma escola pode manter seus alunos, durante um período do dia, a salvo de uma cidade violenta, pode lhes propiciar amizades e momentos de muito prazer, concorrer para sua ascensão social ou para o acúmulo de riquezas de um país assim como, eventualmente, de seus habitantes. Mas, mesmo tenham estreita relação com a escolarização, nem ocupar espaço físico, nem fomentar relações humanas e nem promover o aumento de riquezas materiais são objetivos escolares precípuos. Como lembra Peters:

[...] [é] questionável supor que certas características pudessem ser vistas como essenciais, sem a consideração do contexto e das questões a serem discutidas. No contexto do planejamento de recursos, pode ser correto pensar a educação como algo em que a comunidade possa investir; no contexto da 
teoria de coesão social, a educação pode ser, ingenuamente, explicada como um processo de socialização. Mas, se a considerarmos do ponto de vista da tarefa do professor na sala de aula, essas explicações serão ambas muito gerais e muito ligadas a uma dimensão perigosa, pois encorajam um modo conformista ou instrumental de ver a educação (Peters, 1979, p. 103).

Não se trata de desqualificar os enfoques de outras ciências como a sociologia, a psicologia ou a economia, que costumam também estudar a educação, atribuindo-lhe funções ou salientando seus efeitos. Na verdade, o autor procura chamar a atenção para a especificidade da tarefa escolar e a conseqüente adoção de critérios próprios ao estabelecimento de seus fins, dados a natureza e o sentido do trabalho a ser realizado.

Assim como uma determinada orientação religiosa pode ser determinante para o êxito econômico de algumas nações, como aponta Weber em A ética protestante e o espírito do capitalismo, não cabe reduzir os propósitos e objetivos do protestantismo ao tipo de desenvolvimento que possa proporcionar a um país que o adote como religião oficial. Caso semelhante ocorre com a educação escolar: a ênfase em sua utilidade instrumental - em termos de seu impacto econômico e tecnológico - leva a padronizar extrinsecamente sua qualidade, independentemente dos propósitos que histórica, ética e logicamente estão associados à prática escolar e a própria idéia de uma educação pública. Atribuir à educação escolar uma determinada - e, não raro, exclusiva - finalidade utilitarista é restringir seus objetivos e propósitos. Se sua finalidade é extrínseca, o que resta são a determinação e a busca exclusiva de eficiência e eficácia do trabalho escolar por meio de resultados aferíveis, e nada mais.

Esse modo "conformista ou instrumental de ver a educação", de que nos fala Peters (1979), é justamente a premissa subjacente às diferentes nuances da narrativa instrumental da qualidade cada vez mais preponderante. É inegável que o processo de escolarização tem inúmeras funções e conseqüências, mas fins extrínsecos a ele não podem caracterizá-lo e tampouco distingui-lo de outras atividades como cumprir ordens ou adestrar alguém em alguma habilidade.

Aprender a ler e a escrever na escola pode permitir a um indivíduo que leia uma bula de remédio, elabore um currículo pessoal a fim de obter um emprego ou possa acompanhar um filme estrangeiro legendado, mas não são essas possibilidades que pautam o ensino escolar da leitura e da escrita. Isso se poderia esperar de um treinamento específico, mas, de uma educação escolar, supõe-se que "seus processos e ações contribuam para estabelecer ou 
envolvam algum valor" (Peters, 1979, p. 107) cujo caráter intrínseco não se mensura por provas ou índices de proficiência, mas se avalia pela direção que a orienta.

De um ponto de vista estritamente escolar e do próprio professor preocupado em ensinar crianças e jovens, sua tarefa cotidiana dificilmente é - ou pode ser - orientada por objetivos amplos como o de formar "um bom trabalhador", "ser bem sucedido economicamente" ou desenvolver nos alunos "competências e habilidades" em geral, requeridas pela sociedade de consumo, à qual eles se vêem compelidos a se adaptar. Alheias à atividade escolar, essas metas pouco ou nada dizem sobre o trabalho cotidiano da escola.

Há um exemplo eloqüente disso no próprio ensino de literatura. É de esperar que muitos professores de literatura entendam que sua disciplina é da maior utilidade para o êxito no vestibular - aliás, um típico fim extrínseco à educação básica. No entanto, dificilmente um professor de literatura - minimante comprometido com seu oficio, é bom sublinhar - definirá ou atestará o valor e o mérito dessa matéria por sua presença nesse tipo de exame. Pode mesmo ser considerado desrespeitoso por muitos professores que se restrinjam os objetivos do ensino da literatura à aquisição de "habilidades" ou "competências" como a interpretação ou a correção gramatical, para além da obra literária. Como lembra Antonio Candido (2004), a literatura constitui um direito humano inalienável, um fator indispensável de humanização. Trata-se de uma "manifestação universal de todos os homens em todos os tempos [...] não há povo ou ser humano que possa viver "sem a possibilidade de entrar em contato com alguma espécie de fabulação" (p. 137). Além de ser um direito de cidadania, talvez se possa dizer da literatura que ela é parte do processo da humanização dos homens, isto é, que tem um valor tal que por si só a justifica e legitima. Mas não teria sentido perguntar por sua utilidade, esperando dela algum fim extrínseco.

Contudo, a direção que se vem imprimindo à escola pública - assim como à escola particular, evidentemente - aponta uma degradação do sentido da educação, postulando-a apenas como um meio - ainda que não raro como o mais importante - na cadeia que visa a garantir a sobrevivência dos indivíduos e sua adaptação às demandas de uma sociedade de massas pautada pela satisfação das necessidades de consumo e do desejo de continuar consumindo.

Assim, a narrativa instrumental da qualidade é uma expressão contundente do fenômeno moderno, apontado por Arendt, da paulatina e constante perda de sentido da ação humana. 
A crescente ausência de sentido do mundo moderno é talvez prenunciada com maior clareza que em nenhum outro lugar nessa identificação de sentido e fim. O sentido [...] era agora perseguido com o mesmo mecanismo de intenções e meios organizados empregado para atingir os desígnios particulares diretos da ação concreta: o resultado foi como se o próprio sentido se houvesse separado do mundo dos homens e a eles somente fosse deixada uma interminável cadeia de objetivos em cujo progresso a plenitude de sentido de todas as realizações passadas constantemente se cancelasse por metas e intenções futuras (Arendt, 2005, p. 112).

À medida que se pauta pela categoria de meios e fins, a esfera social se vê irremediavelmente marcada pela conseqüente falta de sentido da ação humana, tornando o tempo presente nada mais do que uma etapa provisória ante o futuro já anunciado. É como se boa parte do que fazemos, pensamos e adquirimos fosse assessória e precária não só em termos de objetos estritamente materiais, mas sobretudo de concepções, idéias e mesmo valores.

O parâmetro de uma "boa vida" - em seus vários sentidos, incluídas diretrizes da educação escolar - estão no futuro não como um tempo que ainda não chegou, mas sim um futuro "presentificado" e imerso em nossa vida. Como parte e fundamento das necessidades de ordem econômica, nossa época se pauta por uma indisfarçável tecnocracia ${ }^{58}$ - "a técnica tornada diretamente poder, e não a serviço do poder" - cujo constante progresso instrumental se apresenta como o campo para o qual se devem dirigir todos os projetos humanos, como argumenta Franklin Leopoldo e Silva (2001).

É nesse sentido que as exigências do contexto contemporâneo são a constante adaptação e o fazer, mas não a reflexão. Se o futuro é o "tempo forte" da humanidade, nada mais é ou deve ser permanente, e o foco não deve recair sobre o presente, nem aí marcar passo. As atenções se voltam para um devir absolutamente determinado e praticamente imperativo.

É esse progresso instrumental que doravante aparece como o campo em que se devem inscrever todos os projetos humanos. E, portanto, esses projetos só podem ser delineados no horizonte dessa racionalidade técnica que é capaz de abreviar o tempo, de trazer o futuro até o presente e de fazer do futuro o conteúdo e o sentido do presente. Como o aprimoramento dos meios técnicos já não se distingue dos fins a que estariam destinados, a consequiência é que essa abreviação do tempo torna-se a finalidade - com a grande diferença de que essa finalidade não é posta reflexivamente, mas apenas em decorrência

\footnotetext{
58 “A supremacia da técnica na esfera da atividade encontra seu correspondente na supremacia do mercado na esfera das relações inter-humanas. Os sujeitos singulares anulam-se diante dessa supremacia: tornam-se apenas elementos passivos que atuam como peças componentes da conduta única do sujeito que é o mercado" (Silva, Franklin, 2001, p. 247).
} 
da hipertrofia da racionalidade técnica e do caráter cumulativo do progresso tecnológico. Isso significa que tal acúmulo é exterior ao processo propriamente humano de realizações das finalidades. A esfera dos fins esvaziou-se e foi ocupada pelos meios, o que é simétrico ao esvaziamento do presente, pois é na dimensão do presente que deveria ocorrer a reflexão acerca do equilíbrio entre meios e fins (Silva, F., 2001, p. 245).

Não é casual que os recentes PCN (Brasil, 1997) e as matrizes curriculares de referência para os grandes sistemas de avaliação em larga escala (1997) utilizadas pelo Saeb e Prova Brasil adotem uma concepção pedagógica fundada na necessidade de a escola ensinar a seus alunos determinadas "competências e habilidades", tão valorizadas pela sociedade de consumo. Não é o interesse público ou os objetivos políticos que orientam uma concepção pedagógica como essa, mas sim os interesses privados e difusos dos indivíduos imersos numa esfera social, e não numa esfera pública. É como se apenas nisso consistisse a melhor ou talvez a única meta a ser visada pela escola ${ }^{59}$.

Embora a narrativa meramente instrumental da qualidade se afirme cada vez mais nos corações e nas mentes dos gestores educacionais, dos agentes institucionais e dos alunos que freqüentam a escola, parece haver um hiato entre o enfoque dessa narrativa e o que rigorosamente poderia ser tomado como uma prática educacional. Há algo mais valoroso implicado na noção de educação - especificamente da educação escolar -, presente em muitos usos comuns e cotidianos desse conceito:

O conceito de "educação" não privilegia qualquer tipo particular de processos como treinamento, por exemplo, ou de atividades como fazer preleções; sugere, antes, critérios aos quais os processos como o de treinamento devem se adaptar. Um desses critérios é o de que algo valioso deve se manifestar. Daí, é possível que estejamos educando alguém enquanto o treinamos, mas não necessariamente, pois podemos treiná-lo na arte da tortura. Contudo, a exigência de que deve haver algo de valor no que está sendo transmitido não pode ser concebida com a significação de que a própria educação nos levaria a algo de valor ou produziria algo de valor. Isso é o mesmo que dizer [...] que a reforma deve fazer com que um homem seja melhor. A questão é a de que fazer um homem melhor não é um fim extrínseco à reforma: é um critério que algo deve satisfazer para ser chamado de "reforma" 60 (Peters, 1979, p. 107).

\footnotetext{
${ }^{59}$ Independentemente do êxito que eventualmente obtenha um ensino alegadamente orientado por essas matrizes curriculares, é o significado mesmo de educação que delas se depreende que merece ser discutido e questionado, pois "competências e habilidades", ou qualquer outro parâmetro de qualidade em educação formulado em termos estritamente instrumentais, são, como diz Passmore, "capacidades para opostos" (1984, p. 168), algo como um remédio que, conforme a dose, pode curar ou matar.

${ }^{60}$ O termo "educação" aqui remete a uma educação escolar ou escolarização, pois não seria difícil encontrar, no português, sensíveis diferenças quanto ao significado dessas palavras. Talvez a principal delas resida no fato de que em "educação" se podem incluir inúmeras atividades cotidianas como dar uma informação na rua, ensinar uma criança a amarrar o cadarço do sapato ou qualificar uma pessoa como atenciosa e cordial. Diferentemente
} 
Essa definição de educação e seu inegável caráter programático transcendem a mera descrição do que é educação ou de como ela deve ocorrer num determinado sistema de ensino. Há aqui um valor intrínseco atribuído à formação escolar, como se a educação, independentemente de qualquer "demanda social" ou utilidade imediata que possa eventualmente proporcionar, possuísse um valor intrínseco, algo que valha a pena realizar independente de qualquer outra coisa.

Nesses termos, poderíamos situar a qualidade da educação a partir da formação de um "espírito público" que oriente a ação escolar, isto é, a formação dos sujeitos forjada pela "finalidade do aprender como atividade constitutiva do ser do homem", como sugere Leffort (1999, p. 222), ao discutir o fenômeno atual do desaparecimento do "ideal humanista" da

educação. É dessa forma que, analogamente às palavras de Peters, podemos dizer que a qualidade em educação não pode ser um fim extrínseco à escola pública: é um critério que algo deve satisfazer para ser chamado de "escola pública".

\subsection{Natalidade e iniciação pública}

Por mais que se atribua um caráter meramente instrumental à educação escolar, há algo inerente à formação de seres humanos que escapa aos eventuais fins extrínsecos que um processo de escolarização vise a atingir. Trata-se daquilo que Arendt (2005) denominou "natalidade", ou o "fato de que seres humanos nascem para o mundo", o que implica não só a necessidade de se assegurar a sobrevivência dos recém-chegados como condição de manutenção da vida humana, mas também sua introdução num mundo preexistente: o mundo humano. Sob essa perspectiva, a criança, em sua condição de objeto da educação, por assim dizer, deve ser considerada num duplo aspecto, pois:

[...] é nova em um mundo que lhe é estranho e se encontra em processo de formação; é um novo ser humano e é um ser humano em formação. Esse duplo aspecto não é de maneira alguma evidente por si mesmo, e não se aplica às formas de vida animais; corresponde a um duplo relacionamento, $\mathrm{o}$ relacionamento com o mundo, de um lado, e com a vida, de outro. A criança partilha o estado de vir a ser com todas as coisas vivas; com respeito à vida $\mathrm{e}$ seu desenvolvimento, a criança é um ser humano em processo de formação, do mesmo modo que um gatinho é um gato em processo de formação. Mas a

desses significados, o termo "escolarização" designa uma formação educação circunscrita a uma instituição social determinada, norteada por certas práticas, valores e objetivos característicos. 
criança só é nova em relação ao mundo que existia antes dela, que continuará após a sua morte e no qual transcorrerá sua vida (Arendt, 2005, p. 235).

Para a autora, vida e mundo não são a mesma coisa. Em sua dimensão estritamente biológica, a vida humana não se distingue do mesmo impulso vital de outros seres vivos, marcados pelos esforços de preservação no "treinamento e na prática do viver que todos os animais assumem em relação a seus filhos" (Arendt, 2005, p. 235). É assim que, por meio da atividade do labor, o homem supre suas necessidades vitais, garantindo a sobrevivência e a manutenção dos indivíduos e da própria espécie humana.

Ao ganhar a vida, os seres humanos também se vêem na condição de recém-chegados a um mundo comum, um lastro capaz de nos ligar àqueles que vieram antes de nós, nossos antepassados, assim como gerações às futuras. Assim, a natalidade se refere ao compartilhamento de formas de vida e tradições públicas de conhecimento forjadas a partir de uma "linguagem pública que exigiu, de nossos remotos ancestrais, séculos para se desenvolver" (Peters, 1972, p. 120), ou a uma herança assegurada a cada pessoa, pelo simples fato de ela compartilhar a condição humana.

Como herdeiros legítimos do mundo humano, os indivíduos que o adentram a cada nova geração têm a condição potencial de reordená-lo e modificá-lo, o que de forma alguma implica um sentido necessariamente positivo à ação humana responsável por suas eventuais transformações. Uma herança pode tanto ser acrescida como esvaziada, e mesmo desaparecer, sobretudo se se compõe de bens imateriais e simbólicos, dependentes não de um testamento ou de uma escritura de propriedade, mas adquiridos pela aprendizagem - em especial através de formas institucionalizadas de ensino. É a aprendizagem que possibilita a participação em um mundo comum, transcendente à duração da vida dos indivíduos que por ele passam e que, nas palavras de Michael Oakeshott (1968):

[...] só pode ser penetrado, possuído e desfrutado por meio de um processo de aprendizagem. Pode-se comprar um quadro, mas não a compreensão que dele se possa ter. E chamo a esse mundo herança comum porque penetrá-lo constitui a única forma de se tornar um ser humano, e viver nele é ser um ser humano. A criança se inicia nesse geistige welt, mesmo em suas tenras aventuras de consciência, e é tarefa do professor iniciar seus alunos nele. Não só a aprendizagem é o único meio para penetrá-lo, como ele se constitui na única coisa que o aluno tem diante de si para aprender (p. 158).

Evidentemente, há muitas instâncias responsáveis pela introdução das crianças e dos jovens no mundo público. O aprendizado da língua materna, por exemplo, assim como muitos valores e saberes de uma dada cultura que se aprendem primeiramente no âmbito familiar. 
Essa e outras diversas formas de introdução ao mundo, em suas várias graduações e especificidades, dependem do contexto social e histórico em que ocorrem, assim como de suas circunstâncias, procedimentos e objetivos. Destaca-se aqui a vocação do trabalho escolar a partir de um tipo de trabalho e ação orientados por um viés e propósito distintos de outras formas de acolhida aos recém-chegados, marcadamente público e, em princípio, destinado a todos.

No âmbito institucional da escola, a natalidade se caracteriza pela tarefa de iniciar crianças e jovens em certas tradições de conhecimento e formas de vida comuns. Uma iniciação que parte da herança humana mais extensa e variada, notadamente pública, pautada em:

[...] formas mais características de conhecimento tais como ciência, história, matemática, religião e apreciação estética, e em tipos práticos de conhecimento que estão envolvidos nas formas de pensamento e ação de natureza moral, consultiva e técnica. Essas diferenciações são estranhas ao espírito de uma criança e de um homem primitivo - na verdade, também ao homem anterior ao século XVII. Ter um espírito não significa desfrutar de um cinema particular ou exercitar algum órgão diáfano interior; significa ter uma consciência diferenciada de acordo com os cânones implícitos em todas essas tradições herdadas. "Educação" assinala o processo por meio do qual o individuo é iniciado em tais tradições (Peters, 1979, p. 121).

A educação como "iniciação" compreende as várias nuances de uma prática educacional escolar, desde a transmissão de conhecimentos e a reflexão direcionada sobre eles até a experimentação de formas de vida e convivência possíveis apenas numa instituição responsável por uma formação pública. Essa iniciação implica não só que algo valioso deva ser ensinado, mas também que as "atividades e os modos de conduta praticados e cultivados na escola sejam coerentes com os princípios maiores que os animam (Peters, 1979, p. 120).

É dessa forma que a vocação escolar e a sua tarefa de iniciação dos jovens num mundo público se reveste de uma grande responsabilidade, cuja importância reside na própria continuidade do mundo e na possibilidade de sua constante renovação. Na condição de agente institucional escolar, o professor se apresenta a seus alunos como representante de um mundo pelo qual deve assumir a responsabilidade. Segundo Arendt (2005), na educação, essa responsabilidade pelo mundo assume a forma de "autoridade". 
É o reconhecimento da escola como o espaço que assume a responsabilidade pelo mundo que lhe impõe a tarefa de assegurar o acesso às grandes tradições de conhecimento ${ }^{61}$. Evidentemente, nossas heranças não consistem apenas de descobertas brilhantes ou fatos heróicos, mas também de atos cometidos pelo homem ao longo da sua existência que, aos olhos de hoje, podem ser considerados equivocados ou condenáveis. Certamente essa é uma parte da responsabilidade que deve assumir a escola, até como forma intencional de expor e discutir exemplos da ação humana através dos tempos, a fim de que as gerações futuras possam compreendê-los e sobre eles refletir.

Contudo, sempre se poderá alegar que uma iniciação em tradições de conhecimento demanda necessariamente o aprendizado de certas "habilidades e competências". Ainda que sob uma denominação discutível ${ }^{62}$, não se pode ignorar que a educação escolar compreende o ensino daquilo que preferimos chamar "capacidades", assim como certas habilidades. O ponto aqui não é o questionamento estéril acerca do fato de a escola inevitavelmente ensinar capacidades e habilidades aos alunos, mas sim a ênfase e a direção que toma essa orientação.

É evidente, por exemplo, que capacidades como as de ler, escrever, contar, interpretar textos são fundamentais, mas cumpre notar que essas e outras capacidades - como a desejada “capacidade de resolver problemas" - não são aprendidas isoladamente, mas imersas em informações e conhecimentos que lhes conferem características peculiares.

Talvez, visar à aquisição de “competências e habilidades" como finalidade precípua de uma formação escolar, imputando a disciplinas ou conteúdos escolares a condição de meios apenas, seja uma espécie de equivoco teórico-conceitual (Carvalho, 2001; Azanha, 2006). Não se pode deduzir que qualquer conteúdo, dependendo apenas da forma como é trabalhado, proporcione indistintamente a aquisição de capacidades e competências ou, mais

\footnotetext{
61 "Na medida em que a criança não tem familiaridade com o mundo, se deve introduzi-la aos poucos a ele; na medida em que ela é nova, deve-se cuidar para que essa coisa nova chegue à fruição em relação ao mundo como ele é. Em todo caso, todavia, o educador está aqui em relação ao jovem como representante de um mundo pelo qual deve assumir a responsabilidade, embora não o tenha feito e ainda que secreta ou abertamente possa querer que ele fosse diferente do que é. Essa responsabilidade não é imposta arbitrariamente aos educadores; ela está implícita no fato de que os jovens são introduzidos por adultos em um mundo em contínua mudança. Qualquer pessoa que se recuse a assumir a responsabilidade coletiva pelo mundo não deveria ter crianças, e é preciso proibi-la de tomar parte em sua educação (Arendt, 2005, p. 239).

${ }^{62} \mathrm{Na}$ critica a essa concepção pedagógica, Azanha (2006. p. 182) destaca que o conceito de competência "referese antes ao grau de excelência que se consegue no desempenho de uma atividade específica do que à posse de algo nebuloso que deve ser desenvolvido em escolas de formação geral". Nesse sentido "em cursos de formação geral (ensino fundamental e médio), não há espaço para que se incluam dentre seus objetivos o desenvolvimento de competências, isto é, o alcance de graus de excelência no desempenho de uma ou outra atividade. Esse desenvolvimento, quando possível, será sempre fruto de um persistente empenho e de firme propósito individual, apenas cabíveis em cursos ou treinamentos especializados, mas não em cursos de formação geral. Estes apenas poderão estimular que desenvolvimentos individuais sejam buscados além dos patamares básicos e coletivos de desempenho exigidos".
} 
especificamente, "flexibilidade, criatividade, autonomia, capacidade de resolver problemas, de fazer escolhas e de continuar aprendendo" (Mello, 1993, p. 67). De fato, é pouco provável que teóricos ou agentes escolares consigam fornecer alguma metodologia ou tecnologia que consiga ensinar a resolução de problemas em geral, independentemente de serem problemas de filosofia, matemática, história ou educação física ${ }^{63}$.

Ainda que seja discutível a plausibilidade do ensino de "competências e habilidades" de forma abstrata, o que se destaca aí é a forma entusiástica com que se concebe a idealização de um futuro já anunciado e inexorável, na mesma proporção em que se vê deliberadamente esquecida do passado, isto é, das próprias "tradições de conhecimento humanas" assim entendidas. Mesmo que para uma sociedade de consumo seja conveniente que os indivíduos tenham certas habilidades e capacidades, muitas das quais efetivamente presentes no trabalho escolar, uma educação pública requer uma direção diferente da que possa se apresentar como imediatamente útil. Segundo Oakeshott:

Iniciar o aluno no mundo das realizações humanas é pôr ao seu alcance muitas coisas que não se apóiam na superfície do mundo presente. Uma herança pode conter coisas caídas em desuso, abandonadas ou esquecidas. Conhecer somente o predominante é familiarizar-se com uma versão atenuada dessa herança. Ver-se refletido no espelho do mundo atual é ver a imagem tristemente distorcida de um ser humano; porque nada nos autoriza a crer que estamos diante da parte mais valiosa de nossa herança, ou que o melhor sobrevive com maior facilidade que o pior. E nada sobrevive sem o apreço humano. A tarefa do professor (na verdade, isso pode ser apontado como sua característica peculiar de agente de civilização) é a de libertar seus alunos da servidão dos sentimentos, das emoções, das idéias, das crenças e mesmo das habilidades dominantes não mediante a invenção de alternativas que lhe pareçam mais desejáveis, mas colocando à disposição desses alunos algo que os aproxime da totalidade de sua herança (1968, p. 162).

A ênfase no que a escola pode oferecer de instrumental aos seus alunos é, como diz Oakeshott, apresentar-lhes apenas uma "versão atenuada de nossa herança". Nesses termos, a

\footnotetext{
${ }^{63}$ Ao discutir alguns aspectos do discurso das Diretrizes Curriculares Nacionais, Carvalho (2001) apresenta um argumento que mina a expectativa de que se possam adquirir competências e capacidades (ambos conceitos utilizados pelas Diretrizes) de forma abstrata e indiscriminada: "a idéia de que deveríamos ter como objetivo o desenvolvimento de uma capacidade abstrata chamada 'pensamento crítico' em relação a qualquer conteúdo ou procedimento é apenas um 'meio', é no mínimo muito problemática, senão absurda. Há tantos tipos de 'pensamento crítico' quanto tipos de conhecimento. É perfeitamente possível e bastante freqüente que uma pessoa tenha capacidade crítica em um campo determinado, e não em outro. Um grande crítico de arte pode ser absolutamente acrítico em termos políticos ou em suas relações pessoais. A capacidade crítica que podemos desenvolver em um ou outro campo não se dissocia do conhecimento que temos dele. Por outro lado, a transferência e aplicação de uma capacidade como essa a outro campo é um assunto complexo e ainda muito obscuro. Assim, embora seja possível acumular conhecimentos sem desenvolver a capacidade crítica, não é possível desenvolver a capacidade crítica sem possuir conhecimentos e informações. Parodiando Kant, "conteúdo sem crítica é cego, mas a crítica sem conteúdo é vazia' e tende a degenerar em mera contestação barata". Disponível em <http://www.scielo.br> Último acesso: 28 abr.2008.
} 
escola pode em maior ou menor grau, apresentar partes dessa herança a fim de desenvolver certas capacidades, mas isto se dará em função de uma razão instrumental, e não como algo que possua um valor em si e um potencial caráter formativo. Não se trata aqui de a escola se divorciar por completo das condições de manutenção e perpetuação da vida - que, inclusive converte-se em condição para a própria existência e perpetuação do mundo humano. A grande questão é a de sobrepor supostas necessidades ao sentido público da herança humana, à continuidade de um mundo que transcende aquilo que é estritamente utilitário e, por isso mesmo, visa a liberdade do cidadão e não o mero condicionamento do individuo.

Esse gradativo e constante esvaziamento da herança humana - ou o que Arendt (2005) denomina como tradição - pode ser percebido pela perda do "fio que nos guiou com segurança através dos vastos domínios do passado". Não se trata exatamente da perda do passado, pois "tradição e passado não são a mesma coisa", mas da perda da tradição que perpassou e estimulou certos aspectos predeterminados do mundo, algo como um elo entre as sucessivas gerações, conferindo sentido à ação humana. O risco dessa perda é esvaziamento da dimensão de "profundidade na existência humana", "pois memória e profundidade são o mesmo, ou antes, a profundidade não pode ser alcançada pelo homem, a não ser através da recordação" (Arendt, 2005, p. 130).

Ao desvalorizar as tradições humanas de conhecimento em favor daquilo que é economicamente útil - incluídos os interesses individuais de uma difusa esfera social -, a narrativa instrumental da qualidade, assim como muitas das ações políticas tomadas em seu nome, esvazia a educação escolar de um significado público, e essa determinação se converte numa questão política fundamental, talvez anterior a qualquer outra.

O que está em jogo aí é o próprio sentido de uma formação escolar pública, em flagrante contradição com a massificação de um parâmetro de qualidade em educação cuja narrativa instrumental subjacente quer o homem escolarizado antes competente e habilidoso naquilo que pode fazer do que cidadão capaz de enxergar e compreender as coisas do mundo para nele agir livremente ${ }^{64}$.

\footnotetext{
64 "O campo em que a liberdade sempre foi conhecida não como um problema, é claro, mas como um fato da vida cotidiana, é o âmbito da política. E mesmo hoje em dia, quer o saibamos ou não, devemos ter sempre em mente, ao falar do problema da liberdade, o problema da política e o fato de o homem ser dotado com o dom da ação, pois ação e política, entre todas as capacidades e potencialidades da vida humana, são as únicas coisas que não poderíamos sequer conceber sem ao menos admitir a existência da liberdade e é difícil tocar em um problema político particular sem, implícita ou explicitamente, tocar em um problema da liberdade humana. A liberdade, além disso, não é apenas um dos inúmeros problemas e fenômenos da esfera política propriamente dita tais como a justiça, o poder ou a igualdade; a liberdade que só raramente - em épocas de crise ou revolução - se torna alvo direto da ação política é, na verdade, o motivo porque os homens convivem politicamente
} 


\subsection{Qualidade da educação e esfera pública: contornos políticos da formação escolar}

À medida que os homens são introduzidos e iniciados num mundo preexistente, são também capazes de "iniciar algo novo" e imprevisto no mundo. Assim, além de estar intimamente imbricada no processo de escolarização, a natalidade é, ao mesmo tempo, uma "categoria central do pensamento político" (Arendt, 2005, p.170). Nessa possibilidade de constante renovação e transformação do mundo reside um aspecto fundamental da condição humana e do próprio sentido de uma escolarização pública: a especificidade de uma ação política exercida numa esfera pública (Arendt, 2005), muito diferente do mero fazer ou da técnica, como preconiza a concepção pedagógica orientada pelo ensino de "competências e habilidades" alegadamente requeridas pela sociedade.

No entanto, em nosso mundo moderno, a ação se caracteriza pela categoria de meios $e$ fins, como se consistisse numa técnica ou na fabricação de algum objeto que demanda um conjunto de meios para a obtenção do resultado desejado. Assim, não são de estranhar a recorrência do termo "eficiência" ou a insistência em sua busca nos discursos políticos atuais, inclusive os relativos à educação.

No contexto contemporâneo, a ação política se vê comumente submetida aos diversos interesses presentes numa difusa e desigual esfera social, limitando-se a ser apenas uma função desta. E não se alegue que a soma dos interesses particulares ou de determinados grupos sociais equivale ao que se poderia classificar como interesse público. Se há algo em comum entre os indivíduos no âmbito de uma esfera social, é preocupação com os meios de se garantir uma vida cada vez mais confortável por meio da atividade do labor, ou seja, voltada exclusivamente para a busca da satisfação de necessidades vitais. Trata-se de um moto-perpétuo, como é típico de todo metabolismo conformado às suas necessidades.

A ação política como mera função social e a formação do cidadão para agir atestam a relevância política de se discutir o atual sentido da educação e de seu parâmetro de qualidade mais preponderante. Talvez o caráter político imbricado no processo de formação escolar possa ser mais bem apreendido pela notória constatação de uma alegada crise educacional, item quase obrigatório dos atuais discursos educacionais, não raro atrelado a seu par antitético: a narrativa instrumental da qualidade. Em que pese a percepção quase geral de uma crise educacional em função de determinados resultados e desempenhos discentes abaixo do esperado, há muito mais a levar em conta, e de forma preliminar.

organizados. Sem ela, a vida política como tal seria destituída de significado. A raison d être da política é a liberdade, e o seu domínio de experiência é a ação (Arendt, 2005, p. 192). 
O estado crítico atribuído à educação escolar aponta antes uma crise da própria sociedade moderna, cujo indício mais visível talvez seja o desaparecimento de significados comuns e compartilhados, típicos de uma esfera pública. É o que se depreende da veemência com que a sociedade cobra mais "autoridade do professor", na mesma proporção em que esvazia de significado o pressuposto dessa mesma autoridade: a iniciação em tradições públicas de conhecimento e de modos de vida valiosos, desse ponto de vista, assim como a própria condição de o homem agir num mundo público.

Entretanto, a crise pode não ter a conotação negativa que freqüentemente sugere esse tipo de crítica. Uma crise pode tanto resultar desastrosa, quando se a enfrenta com "juízos préformados" e "preconceitos", quanto pode ensejar a exploração e a investigação da "essência da questão" e a reflexão decorrente (Arendt, 2005).

Nesse sentido, por ser a natalidade a "essência da educação" é que a formação escolar pública precisa ser conservadora (Arendt, 2005, 242) não só pelo fato de a vocação escolar estar vinculada à responsabilidade perante o mundo, mas também porque a escola é o potencial lugar de abrigo e proteção de crianças e jovens contra ideais ou modos de vida predeterminados ou qualquer tipo de doutrinação ou visão determinista do mundo a que se devam irremediavelmente adequar.

Aliás, um dos traços característicos da narrativa instrumental da qualidade é a imposição de um padrão de qualidade na educação que dita a "aparência futura" dos alunos e futuros cidadãos. Orientada por esse propósito, a educação só pode significar "o desejo de arrancar das mãos dos recém-chegados sua própria oportunidade face ao novo", ou seja, de impedi-lhes a ação política, necessariamente livre ${ }^{65}$, no mundo. É nesse sentido que, do ponto de vista dos recém-chegados, uma idealização do futuro será sempre "mais velha que eles mesmos" (Arendt, 2005, p. 221).

Nossa esperança está pendente sempre do novo que cada geração aporta; precisamente por basearmos nossas esperanças nisso, porém, é que tudo destruímos se tentarmos controlar os novos de tal modo que nós, os velhos, possamos ditar sua aparência futura. Exatamente em beneficio daquilo que é

\footnotetext{
${ }^{65}$ Não obstante a identificação generalizada da liberdade com um aspecto subjetivo do individuo - fruto, por exemplo, da escolha individual mediada pela vontade -, a ação política é condição objetiva da liberdade, "uma realidade mundanamente tangível", a partir experiência grega que a originou: "Antes que se tornasse um atributo do pensamento ou uma qualidade da vontade, a liberdade era entendida como o estado do homem livre, que o capacitava a se mover, a se afastar da casa, a sair para o mundo e a se encontrar com outras pessoas em palavras e ações. Essa liberdade, é claro, era precedida da liberação: para ser livre, o homem deveria ter se libertado das necessidades da vida. $\mathrm{O}$ estado da liberdade não se seguia automaticamente ao ato de liberação. A liberdade necessitava, além da mera libertação, da companhia de outros homens que estivesse no mesmo estado e também de um espaço público comum para encontrá-los - um mundo politicamente organizado, em outras palavras, no qual cada homem poderia inserir-se por palavras e feitos" (Arendt, 2005, p. 194).
} 
novo e revolucionário em cada criança é que a educação precisa ser conservadora; ela dever preservar essa novidade e introduzi-la como algo novo num mundo velho, que, por mais revolucionário que possa ser em suas ações, é sempre, do ponto da geração seguinte, obsoleto e rente à destruição (Arendt, 2005, p. 243).

Não se pode confundir a idéia de conservação com a manutenção do status quo e a inadmissível desigualdade material que caracteriza a sociedade de consumo, assim como não se pode interpretá-la com uma metodologia de ensino "moralizante", "disciplinadora" ou que contenha qualquer outro reducionismo tão comum no discurso educacional. Trata-se de dar continuidade às tradições de conhecimento e a suas respectivas experiências e modos de vida, por meio de sua transmissão aos recém-chegados no mundo. Seguramente, não é essa a concepção corrente no debate acerca da qualidade da educação.

Termos como "tradição" e "conservação" são notoriamente tratados de forma pejorativa no discurso educacional, não raro em oposição a uma educação mais aberta e "democrática". Trata-se do que Arendt chamou "pathos do novo", ou o fascínio pelo que se apresenta como novidade, como é o caso da constante sucessão de metodologias e técnicas de ensino, na mesma proporção em que se despreza aquilo que rapidamente se passa a considerar "ultrapassado", "antiquado" ou "tradicional”. É possível que essas dicotomias escamoteiem os próprios termos em que se assenta a vocação de uma formação escolar pública e sua estreita ligação com a possibilidade de o homem participar ativa e livremente da política e dos negócios públicos.

Aliás, é comum que a ênfase no aspecto instrumental da escola venha atrelada à crítica das formas "tradicionais" de conhecimento, como se estas servissem à doutrinação e ao cerceamento do potencial imaginativo e crítico do aluno. Uma compreensão tão abstrata - e preconceituosa - do que é uma tradição e de seu papel na formação pela qual a escola é - ou deveria ser - responsável é no mínimo equivocada, pois:

[...] não há antítese entre iniciar os jovens em grandes tradições e ensiná-los a serem críticos; as grandes tradições são tradições de crítica, ainda que não sejam ensinadas como tal. [...] O espírito critico que o professor se interessa em desenvolver significa a capacidade de ser participante critico de uma tradição, mesmo se o efeito de tal crítica for a modificação profunda dos modi operandi dessa tradição (Passmore, 1984, p. 193).

Por outro lado, a própria idéia de uma educação democrática, em termos estritamente pedagógicos, é passível de discussão e questionamento quanto ao seu papel e interesse em uma formação escolar pública. A começar pelo fato de que a democracia pressupõe a 
igualdade entre os pares e a escola é o lugar em que esse tipo de igualdade, requerida por uma esfera política e pública, simplesmente não pode existir entre professores e alunos.

De forma alguma esta ausência de igualdade entre os papeis exercidos pela escola equivale a um cerceamento de uma formação da cidadania ou a formação para a vida política e democrática. Mesmo porque, formar para a democracia - e consequentemente para esfera política - não significa reproduzir os mesmos mecanismos da ordem social legal nas salas de aula. Se a escola assim o fizer, estaremos correndo o risco de criar alunos tiranos acostumados a "ditaduras de maiorias" do que a indivíduos sensíveis à causa democrática.

Ao tentar imprimir à rotina escolar os procedimentos da organização política vigentes numa sociedade democrática, desvirtuam-se sobremaneira certas responsabilidades inerentes a uma instituição escolar:

Imaginar que a vivência da liberdade no âmbito da escola capacite para o exercício da liberdade na vida pública é, de certo modo, deixar-se embair por um simulacro pedagógico da idéia de democracia. A liberdade na vida escolar, por ilimitada que seja, ocorre num contorno institucional que pela sua própria natureza e finalidade é inapto para reproduzir as condições da vida política (Azanha, 1987, p. 39).

Ainda que seja comum no campo educacional associar a democracia à "liberdade do educando", é inimaginável, por exemplo, que um aluno tenha condições de escolher aquilo que quer aprender, uma vez que, por definição, aluno é aquele que aprende aquilo que não sabe. Por sua própria especificidade, a organização escolar exige a hierarquia e o estabelecimento da autoridade de um segmento sobre outro. Professores e alunos não podem se igualar ou equivaler, pois estão em posições necessariamente diferentes ${ }^{66}$, embora isso não exclua que a escola possa - ou mesmo deva- ser um fórum de participação dos sujeitos nela envolvidos, levando em conta os papeis institucionais ali exercidos ${ }^{67}$.

\footnotetext{
66 “Ao professor cabe esse papel de agente institucional responsável simultaneamente pela preservação de certos saberes, valores e práticas que uma sociedade estima e pela inserção social dos novos nesse mundo da cultura humana. Assim, embora o professor ensine e aprenda, inclusive de seus alunos, e através de seu ensino eduque e seja educado, o contexto institucional em que ele o faz não deve permitir que os papéis se confundam, nem tampouco pode implicar uma igualdade, como se o contexto político das relações entre cidadãos se reproduzisse de forma idêntica ou imediata no contexto escolar e entre professores e alunos" (Carvalho, 1998, p. 26).

${ }^{67}$ Como se sabe, é corrente no discurso educacional brasileiro a expressão "gestão democrática do ensino ou da educação". Mesmo a LDB vigente lança mão dela em mais de uma oportunidade, para situar a escola como um espaço a ser ocupado, principalmente por seu corpo docente, de forma democrática. Ou seja, que caiba aos professores a formulação da proposta pedagógica pela qual trabalharão e, em última instância, a responsabilidade pelos rumos da escola. Há ainda outros desdobramentos mais ou menos interessantes desse conceito, como, por exemplo, a eleição direta para diretor de escola, mas "a educação para a democracia não se confunde nem com democratização do ensino - que é, certamente, um pressuposto -, nem com educação democrática. Esta última é um meio, necessário mas não suficiente, para se obter aquela. A verdade é que, sem dúvida, uma organização
} 
Uma educação voltada para os valores do regime democrático não deve confundir as práticas pelas quais se exerce a democracia no espaço público social com as tarefas especificas que se desenvolvem na escola. As especificidades e os contornos institucionais de uma escola não permitem convertê-la num simulacro de mundo: "a escola não é de modo algum o mundo e não deve fingir sê-lo [...] em relação à criança, a escola representa o mundo, embora ainda não seja o mundo de fato" (Arendt, 2005, p. 239).

Pela conservação de determinados aspectos do legado humano, a educação tem um significado fundamental na formação do cidadão, aqui entendida como sua própria formação política. Ao tomar posse de sua herança por meio da escolarização, os recém-chegados se mantêm, em alguma medida, ligados à sua condição humana histórica, isto é, assumem de algum modo sua cota de participação no mundo, ao mesmo tempo em que se vêem liberados de ter que reinventar a roda ou de reproduzir na vida adulta experiências já transformadas - e muitas vezes superadas - pelo conhecimento humano canonizado ou pelo próprio acúmulo de experiências. Nessa perspectiva, a escola tem uma dupla responsabilidade: a preservação das tradições de conhecimento e formas de vida de um mundo preexistente - do qual os recémchegados vão se apropriando gradualmente - e a possibilidade de agir sobre esse mundo, renovando-o. É nesse sentido que se fala em conservação:

[...] apenas no âmbito da educação, ou melhor, nas relações entre adultos e crianças, e não no âmbito da política, onde agimos em meio adultos e como iguais. Tal atitude conservadora, em política - aceitando o mundo como ele é, procurando somente preservar o status quo -, não pode levar senão à destruição, visto que o mundo, tanto no todo como em parte, é irrevogavelmente fadado à ruína pelo tempo, a menos que existam seres humanos determinados a intervir, a alterar, a criar aquilo que é novo (Arendt, 2005, p. 242).

O sentido de uma ação política reside em ser esta uma manifestação autenticamente humana, uma forma de relacionamento entre pares que têm a responsabilidade de discutir e agir sobre o mundo comum. Não está subordinada a qualquer objetivo predeterminado, gerado a partir de algum segmento da sociedade ou pela "certeza de demandas futuras" às quais os indivíduos devem necessariamente se adequar. Antes se configura como uma condição capaz de perpetuar um mundo comum, através da sua permanente modificação. A ação política numa esfera pública se configura como uma autêntica forma de vida, valorosa em si mesma e marcada pelo sentido de agir conjuntamente em meio à pluralidade de indivíduos e a partir de 
um elo comum capaz de distinguir uns dos outros. É na esfera pública que o cidadão pode, por suas palavras e ações, afirmar sua singularidade como alguém que jamais existiu ou existirá no mundo.

A educação guarda estreita ligação com a ação numa esfera pública não porque “instrui as crianças na arte de viver", mas porque deve ensiná-las "como o mundo é” (Arendt, 2005 , p. 246). Trata-se de uma formação que reconhece a natalidade e a iniciação no mundo humano como seu fundamento, assume a responsabilidade por esse mundo sob a forma da autoridade a partir de uma herança pública e comum e permite que, de posse dessa herança, o indivíduo renove o mundo do qual passa a fazer parte.

Assim, a formação escolar pública acolhe "uma espécie de indeterminação, já que quem aprende está sendo requisitado não tanto para dominar um certo lote de conhecimentos, mas sim para travar um novo relacionamento com o saber" (Lefort, 1999, p. 211 - grifo do original), ou com sua herança humana. Esse caráter indeterminado da educação é pressuposto também de uma esfera política e pública: a imponderabilidade da ação humana no exercício de sua liberdade. E esse não deixa de ser um critério pelo qual podemos afirmar que um aluno tenha de fato aprendido algo: quando demonstra saber alguma coisa que não tenha sido dada numa determinada aula ou disciplina, mas que só lhe foi possível aprender pela educação e pelo discernimento que desenvolveu em sua formação escolar.

Essa indeterminação, contudo, não significa falta de clareza ou de objetividade e nem se trata de quanto conhecimento ou de que "habilidades" o aluno deve deter e ser capaz de demonstrar. Pensemos, por absurdo, que, se todos os alunos alcançassem um mesmo desempenho escolar, aprendessem as mesmas coisas e da mesma forma, além de o mundo se tornar monótono e previsível, restaria pouco ou nenhum espaço para a constituição de sujeitos singulares que pudessem agir livremente a partir do que - por direito de cidadania - lhes teria proporcionado a escola.

Entendida como formação, a qualidade da educação não pode ser mensurável, pois não tem um limite predefinido. Refere-se antes a um significado e sentido para essa formação escolar, não conformada às necessidades humanas vitais de sobrevivência e consumo, mas que, para além delas, se volta para o que é característico da existência humana: o exercício de uma cidadania ativa numa esfera pública capaz de unir os homens pelo que têm em comum e de distingui-los segundo a singularidade de cada um. A única restrição, por assim dizer, que talvez se possa fazer ao livre agir do homem é a de que não destrua - ou não esvazie de significado - os próprios fundamentos que possibilitam a construção, continuidade e renovação de um mundo comum e público. 
Uma formação pública não se converte automaticamente num parâmetro de qualidade, mas é parte de um critério fundamental para sua avaliação: uma escola que possibilite e favoreça o contato do aluno com sua herança humana, libertando-o para agir politicamente no mundo que gradualmente passa a ser o "seu mundo". Evidentemente, a definição de indicadores e mesmo de um padrão de qualidade - como reza a Constituição - fica a cargo dos gestores dos sistemas públicos de ensino, da forma e dos interesses que prevalecem no planejamento e na execução das políticas educacionais e se isto é feito de forma abrangente e, por assim dizer, legitima.

Nesses termos, a reflexão acerca do significado e sentido de uma formação escolar pública, a partir da análise da qualidade em educação, parece ser de importância e relevância verdadeiramente inestimáveis; não tanto por evidenciar determinados aspectos do que se está fazendo e propondo ultimamente, mas sobretudo por destacar e analisar aquilo que é sumariamente desconsiderado e esquecido no tratamento de uma questão tão relevante. 


\section{CONSIDERAÇÕES FINAIS}

Ao analisar e discutir o conceito de qualidade vinculado ao caráter público da educação, não perdemos de vista que esta análise adquiriu um tom fortemente programático, o que, de modo algum, é um problema. Definições programáticas são comuns no discurso educacional, e a análise e a intenção prática de um discurso não são incompatíveis. Trata-se apenas de um traço peculiar do tipo de investigação que procuramos desenvolver, talvez inevitável face ao interesse político do tema em questão. Como afirmou Arendt, "sempre que a relevância do discurso entra em jogo, a questão torna-se política por definição, pois é o discurso que faz o homem um ser político" (1995, p. 11).

Ainda que haja diferentes definições de qualidade no campo educacional, o forte atrativo ideológico associado ao termo lhe imputa uma imagem auto-explicativa. Afinal, quem se oporia à busca ou à melhoria da qualidade de ensino? Assim, não é contingente que as discussões e análises feitas em torno dessa aparente "bandeira comum" enfatizem mais as propostas preocupadas em como obter uma melhor qualidade do que propriamente um debate preliminar e público acerca do significado e da abrangência do que se quer dizer. O que criticamos aqui é o próprio significado atribuído à educação escolar pública e o sentido que adquiriu no atual estágio da civilização.

Aliás, o contexto contemporâneo não parece ter como traço distintivo a reflexão e a busca de compreensão daquilo que é de interesse eminentemente público e político, como é o caso da qualidade em educação, o que não quer dizer que se deixe de discutir tais assuntos. $\mathrm{Na}$ verdade, o tema da qualidade no campo educacional parece ganhar um amplo destaque quando volta suas atenções para certos resultados desejados e socialmente valorizados, supostamente capazes de viabilizar as condições para se obterem mais e melhores resultados, alimentando um fluxo sem fim e sem sentido.

A própria avaliação da qualidade restrita à mensuração de desempenho discente, formulada em termos da aquisição de "competências e habilidades" pretensamente necessárias e indispensáveis ao "desenvolvimento" do individuo e da sociedade talvez seja o indício mais contundente disso. Não seria demais supor que, nessa perspectiva, qualquer outra dimensão atribuída à educação escolar seja relegada a um segundo plano, à medida que o critério primordial é a utilidade econômica, tão cara aos indivíduos e grupos imersos numa esfera social. Trata-se de um esforço frenético e irrefletido, típico de uma sociedade de consumo orientada por uma idéia de futuro fortemente impregnada no tempo presente, nos valores, nas organizações e práticas sociais atuais. 
Subordinamo-nos ao acúmulo externo de meios e produtos tecnológicos, acúmulo que é visto como progresso mas que representa também um processo que nem sempre esteve acompanhado pela reflexão. É isso que significa dizer que nos apropriamos do futuro de maneira "irreflexiva e irrefletida". Tudo isso é nosso, é produto de nossa atividade, mas ao mesmo tempo nos escapa (Silva, F., 2001, p. 243).

Uma imagem refletida no espelho não mostra, por exemplo, a aparência que teremos em 20 anos ou os traços de que mais gostamos em detrimento de outros. Ela mostra apenas o que somos no momento presente, aquilo que pode ser visto e percebido. Ainda assim, uma imagem sempre pode ser interpretada de diversas formas, segundo critérios distintos.

Por isso, nossa preocupação central foi lançar mão de categorias de análise que não se vinculassem a interesses individuais ou privados ou exclusivos de determinados grupos ou classes sociais, mas que dissessem respeito a todos e por aquilo que têm em comum. Assim analisamos o uso do conceito de qualidade, discutindo-o sob a perspectiva de uma formação escolar autenticamente pública, porque destinada a todos, como um direito universal e inalienável.

É justamente esse caráter público do processo de escolarização que vai cada vez mais perdendo relevância nos discursos educacionais atuais e na compreensão do tipo de inserção da escola numa esfera pública e na própria continuidade do mundo humano. Ao invés de ocupar apenas um aspecto - embora fundamental - da condição humana, a satisfação das necessidades da vida, isto é, o labor prepondera e vem ditando determinados fins extrínsecos à educação escolar. É como se o valor da escola pudesse ser estimado pela riqueza ou pelo status social que proporciona aos indivíduos ou pelo desenvolvimento econômico que traz à sociedade - de forma notadamente desigual em relação aos indivíduos e grupos que a compõem. Esse é o pressuposto de uma narrativa instrumental da qualidade, esvaziada de sentido e voltada para os interesses individuais e privados, e não para um interesse que seja efetivamente público, porque comum aos cidadãos.

Nesses termos, impõe-se um desafio que, em sentido amplo, Arendt já tinha formulado na análise que faz da crise da educação norte-americana em meados do século XX:

O problema da educação no mundo moderno está no fato de, por sua natureza, não poder esta abrir mão nem da autoridade, nem da tradição e ser obrigada, apesar disso, a caminhar em um mundo que não é estruturado pela autoridade nem tampouco mantido coeso pela tradição. Isso significa, entretanto, que não apenas professores e educadores, porém todos nós, na medida em que vivemos em um mundo junto a nossas crianças e aos jovens, 
devemos ter em relação a eles uma atitude radicalmente diversa da que guardamos um para com o outro. Cumpre divorciarmos decisivamente o âmbito da educação dos demais, e acima de tudo do âmbito da vida pública e política, para aplicar exclusivamente a ele um conceito de autoridade e uma atitude face ao passado que lhe são apropriados mas não têm validade geral, não devendo reclamar uma aplicação generalizada no mundo dos adultos (Arendt, 1995, p. 245-246).

A autora indica claramente a necessidade de a educação escolar não abrir mão de algumas prerrogativas, procedimentos e valores próprios em detrimento de outros valores vigentes numa "vida pública" subordinada a uma esfera social conformada às necessidades vitais e aos interesses privados dos indivíduos. Não se trata, como se poderia supor, de desvincular a educação de seu evidente interesse público e político, mas de preservar algumas características suas a fim de que ela favoreça uma formação interessante para o mundo público e que preserve a possibilidade da ação política.

Nesses termos, o trabalho da escola não deve se pautar por um ideal de futuro - que, por definição, não passará de uma aposta - ao qual devemos nos agregar e adequar, mas antes de estabelecer e manter um fio condutor que nos ligue a alguns aspectos valiosos do passado comum, à nossa herança de realizações humanas. É essa espécie de conservadorismo daquilo que é, por direito, comum todos que se pode depreender da própria noção de uma autêntica formação da cidadania. Longe de se restringir a uma melhor inserção produtiva na sociedade de consumo, a cidadania é a possibilidade de ação política capaz de renovar o mundo comum.

Propor uma visão de mundo antecipada e inexorável é, como diz Arendt, "arrancar da mão de crianças e jovens a oportunidade de empreender alguma coisa nova e imprevista por nós". É privar cada vez mais as gerações futuras de uma formação que favoreça sua participação numa esfera pública e política e sua ação, em nome da conformação às discutíveis necessidades do contexto contemporâneo.

A ênfase na escola como o espaço capaz de uma formação pública pressupõe não só uma discussão de significados atribuídos à sua qualidade, mas a reflexão em torno das ações que se façam nesse sentido, cujo detalhamento e aprofundamento não foram objeto deste trabalho. Ainda assim, pode ser interessante identificar algumas contendas e dilemas no que diz respeito a uma plena formação nesses termos.

Não se pode perder de vista que a narrativa instrumental da qualidade não substitui automaticamente outras narrativas criadas e sustentadas por uma cultura escolar (Azanha, 2005) fortemente arraigada, em suas diversas manifestações e características peculiares. Trata-se de considerar e discutir as razões pelas quais a escola realiza seu trabalho e o que é 
efetivamente feito. Isso implicaria talvez a compreensão do conceito de qualidade aplicado à escola pública a partir de diversos componentes que concorrem para uma formação pública desejada. Como vimos, a proficiência dos alunos, de forma geral, é um indicador importante mas não exclusivo da qualidade da formação escolar. Daí o imperativo de não se limitar a qualidade ao que os alunos demonstram saber.

É fundamental investigar e discutir certos aspectos da cultura escolar desinteressantes e potencialmente prejudiciais à formação de futuros cidadãos como, por exemplo, a prática das reprovações escolares em massa e suas justificativas ou a composição de salas de aulas homogêneas por comportamento ou proficiência, como é comum. Destaca-se aqui o próprio valor formativo dos procedimentos e práticas discursivas e não discursivas que não são objeto de exames padronizados. Por esse viés, a discussão da qualidade em educação ganha outros contornos e se volta para o significado, os objetivos e as justificativas que estão em jogo na formação escolar cotidiana.

Contudo, investigar e debater o conceito de qualidade vinculado a procedimentos e práticas educacionais - e não apenas em termos de seus resultados aferíveis em avaliações de larga escala ou do impacto econômico da escolarização na sociedade - não se confunde com a formulação de um índice de qualidade multifacetado.

A idéia de um índice de qualidade em educação que abordasse não só a proficiência dos alunos mas também elementos considerados valiosos dos processos educacionais é potencialmente interessante, à medida que traz para o centro do debate a compreensão da qualidade em educação como uma prática carregada de significações, e não restrita a resultados mensuráveis. Mas, ainda que amplamente discutida e acordada, a formulação de um índice de qualidade em educação acarreta sérios riscos como os que se vêm verificando, por exemplo, com a utilização do Índice de Desenvolvimento Humano - IDH (Guimarães \& Jannuzzi, 2005).

Outro exemplo é o Índice de Desenvolvimento da Educação Básica - IDEB -, instituído em 2007 no âmbito do Plano de Desenvolvimento da Educação - PDE -, composto pela combinação de "resultados de desempenho escolar (Prova Brasil) e os resultados de rendimento escolar (fluxo apurado pelo censo escolar) num único indicador de qualidade" (Haddad, 2008, p. 12), através do qual o IDEB sem dúvida rompe com o significado da qualidade restrita a resultados de desempenho cognitivo, destacando também um problema da maior importância ante o direito à educação: a alta reprovação escolar que ainda persiste no Brasil - um desafio indiscutível, a despeito do parâmetro de qualidade adotado. Contudo, 
mesmo a incorporação dessa importante dimensão nesse índice não parece ter rompido os termos instrumentais e utilitários fortemente associados à qualidade no discurso educacional vigente. Não será surpresa se a questão da qualidade, agora, se ativer a melhorar os próprios índices, e não as praticas educativas. A tentativa de operacionalização de um conceito como o de "qualidade" o empobrece ao ponto de suas diversas dimensões se exprimirem por um resultado numérico. É como trocar significados por números.

Por outro lado, um índice que abarcasse, por exemplo, itens importantes como o trabalho escolar coletivo e o peso negativo de uma classificação dos alunos em salas homogêneas ${ }^{68}$ poderia mascarar outros aspectos, igualmente importantes. Uma rede de ensino poderia organizar homogeneamente suas salas de aula e ainda assim ter uma razoável condição de trabalho coletivo. Na média desses dois aspectos, nenhum deles se destacaria numa discussão acerca da qualidade oferecida.

Mais interessante do que um índice de qualidade pautado na ponderação de certos elementos considerados valiosos em termos de uma prática escolar seria o próprio destaque de cada um deles em seu caráter formativo e em sua objetividade para um eventual acionamento na Justiça, uma vez detectada sua falta. A hora de trabalho pedagógico coletivo é um bom exemplo.

O trabalho coletivo docente é previsto na LDB, em especial em seus Artigos $12^{\circ}, 13^{\circ} \mathrm{e}$ $14^{\circ}$, postulando que as unidades escolares, por meio de seus agentes institucionais - incluídos os docentes - deve não só executar uma proposta pedagógica, mas também elaborá-la, o que demanda tempo remunerado no início do ano letivo e também ao longo do período escolar. Mas isso não significa que as redes de ensino tenham regulamentado esse princípio. Muitos sistemas públicos de ensino não prevêem na jornada de trabalho docente horas destinadas exclusivamente à discussão coletiva dos problemas e caminhos a serem percorridos pelas unidades escolares. Também é comum que, uma vez instituídas, essas horas de trabalho coletivo sejam usadas para outros fins, segundo o interesse privado dos docentes ou como fruto da própria desorganização e do descaso da escola ou de seus agentes institucionais pelo trabalho que têm em mãos, o que evidentemente inclui a discussão e o planejamento coletivo de objetivos, procedimentos e práticas escolares.

\footnotetext{
${ }^{68}$ Um estudo da Unesco propõe como um dos elementos que poderiam configurar uma "escola eficaz", o "Agrupamento de alunos por critérios de heterogeneidade" (Unesco, 1998 apud Oliveira, 2005). Certamente, essa prática não é exclusiva de colégios de elite, mas é comum em muitas escolas e sistemas de ensino públicos. Muitas vezes sob uma justificativa pedagógica, as salas homogêneas acabam acirrando drasticamente a desigualdade educacional e comprometendo o sentido público da formação proporcionada pela escola.
} 
Nesse sentido, a própria formação de professores e o modo como se aborda o caráter público de uma educação escolar nas licenciaturas são aspectos fundamentais a investigar e debater. Na perspectiva de análise da qualidade da educação vinculada à formação dos professores, chama especial atenção o fato de o Estado ter um peso significativamente menor. Como se sabe, isso está cada vez mais a cargo de instituições privadas de ensino superior, cujos interesses se movem por uma lógica de mercado, e não pela melhor formação docente voltada para os interesses da escola pública.

Não é de estranhar que a graduação em Pedagogia, em meio a uma série de prescrições legais passíveis de discussão e crítica, feitas especialmente na ultima década, tenha sido reduzido de quatro para três anos na esmagadora maioria das faculdades e universidades privadas. Pela lógica do mercado, os futuros pedagogos devem conjugar a melhor formação acadêmica a que podem ter acesso com o menor custo, e a opção por um curso em que se pagam as mensalidades por apenas três anos sempre será mais atraente.

Atrelados a esse modelo discutível de acesso aos cursos de licenciatura, a concepção e o modelo de formação docente no Brasil parecem relegar de sua ação a vocação escolar e o sentido público. Como destaca Azanha (1993):

\begin{abstract}
Esses cursos foram organizados a partir de uma concepção do trabalho docente, como se esse consistisse simplesmente em ensinar alguma coisa a alguém. Para realizar com êxito essa tarefa, o futuro professor - um meio especialista em alguma disciplina - aprende algumas noções de didática geral e especial, de psicologia da aprendizagem e legislação. A parte prática da formação é, supostamente, completada por estágios junto a um professor da disciplina em questão. No fundo, essa formação pressupõe que o professor será um preceptor que deverá ensinar algo a alguém numa relação individualizada. Não se trata de fazer uma caricatura, mas de propor uma hipótese, a de que nossos cursos de licenciatura ainda não conseguiram focalizar a relação educativa no ambiente em que ela realmente ocorre, isto é, na sala de aula que, por sua vez, integra-se em uma escola (p. 16).
\end{abstract}

De fato, não se podem dissociar a análise e a discussão do conceito de qualidade em educação do modelo de formação docente praticado no Brasil, assim como parece evidente que as escolas públicas têm uma enorme dificuldade para ensinar consistentemente a seus alunos certas tradições intelectuais e práticas culturais - e, como parte destas, as capacidades de ler, escrever e contar -, na medida em que seus professores mal foram iniciados nessas mesmas tradições. A proposição de novas metodologias de ensino pode eventualmente ser interessante, mas seguramente não é a solução para a transformação e o aprimoramento da qualidade entendida como formação escolar pública. Como vimos, nessa perspectiva, a 
qualidade não é uma questão meramente técnica ou da apropriação de uma teoria ou metodologia de ensino mais moderna e, supostamente, mais eficiente. O tema é eminentemente político e implica a compreensão, discussão e análise das razões pelas quais se forma uma pessoa em âmbito escolar.

Assim, a qualidade da educação compreende e ultrapassa os limites do ensino e da aprendizagem de disciplinas escolares e estabelece um "novo relacionamento com o saber" (Lefort, 1999). Seu aspecto tangível pode ser expresso como o esforço comum de seus agentes institucionais voltados para a formação de uma cidadania ativa num mundo público não apenas retórica, mas a partir de práticas escolares concretas, coerentes com os valores maiores que as animam. Práticas essas que nos levem a compreender o sentido mesmo da expressão "escola pública". 


\section{BIBLIOGRAFIA}

ARENDT, Hannah. A condição humana. São Paulo: Edusp, 1995.

Entre o passado e o futuro. São Paulo: Perspectiva, 2005.

ADAMS, D. Defining Educational Quality. Arlington, VA: Institute for international Research, 1993. (IED Publicaton: biennial report; 1).

ANTUNES, Camila. "Escola pública, gestão particular”. Revista Veja (14/02/2007).

AZANHA, J. M. P. “Avaliação escolar, algumas questões conceituais”. In: A formação do professor e outros escritos. São Paulo: Editora Senac, 2006.

"A pedagogia das competências e o Enem". In: A formação do professor e outros escritos. São Paulo: Editora Senac, 2006.

"Cultura escolar brasileira”. In: Educação: temas polêmicos. São Paulo: Martins Fontes, 1995.

"A estigmatização da escola pública". In: Educação: temas polêmicos. São Paulo: Martins Fontes, 1995.

"Melhoria do ensino e autonomia da escola". In: Educação: temas polêmicos. São Paulo: Martins Fontes, 1995.

Parâmetros Curriculares Nacionais e autonomia da escola. 2001. Disponível em $<$ http://hottopos.com/-International Studies on Law and Education Publishers> Último acesso: 1 abr.2004.

_ "Proposta pedagógica e autonomia da escola". In: Cadernos de Filosofia e História da Educação. Faculdade de Educação, Universidade de São Paulo, v. 2, n. , 1993.

Uma idéia de pesquisa educacional. São Paulo: Edusp, 1992. 
"Democratização do ensino: vicissitudes da idéia no ensino paulista". In: Educação: alguns escritos. São Paulo: Nacional, 1987.

BEISIEGEL, C. A qualidade de ensino na escola pública. Brasília: Casper Livro, 2005.

“Avaliação e qualidade de ensino". In: BICUDO, M. A. V. (org.) Formação do Educador: organização da escola e o trabalho pedagógico, v. 3. São Paulo: Editora Unesp, 1990. p. 40.

BANDEIRANTES estimula a hiperconcorrência entre os alunos. Folha de S.Paulo. 29/04/2005. p. 16.

BONAMINO, Alicia C. Tempos de avaliação educacional: o Saeb, seus agentes, referências e tendências. Rio de Janeiro: Quartet, 2002.

BRASIL. Ministério da Educação e Cultura. Saeb 2001: Relatório Nacional. Brasília, Inep, 2002, 303p.

BRASIL. Secretaria de Educação Fundamental. Parâmetros Curriculares Nacionais: introdução aos PCN. Brasília: MEC/SEF, 1997.

BRASIL. Ministério da Educação, Secretaria de Educação Media e Tecnológica. Parâmetros Curriculares Nacionais: ensino médio. Brasília: MEC, 1999.

CARVAlHO, J. S. F. Construtivismo: uma pedagogia esquecida da escola. Porto Alegre: Artmed, 2001.

“A qualidade de ensino vinculada à democratização do acesso à escola”. In: Estudos Avançados. São Paulo: Universidade de São Paulo, n. 60, 2007.

_ "Apontamentos para uma crítica das repercussões da obra de Paulo Freire". In: Cadernos de História e Filosofia da Educação, Universidade de São Paulo, v. 2, n. 4, 1998. 
"O discurso pedagógico das diretrizes curriculares nacionais: competência crítica e interdisciplinaridade”. In: Cadernos de Pesquisa, n. 112. São Paulo, mar.2001.

MOURA CASTRO, Cláudio. “Autópsia do fracasso”. Veja, n. 1990 (10/01/2007).

CASTRO, Maria Helena Guimarães. A educação para o século XXI: o desafio da qualidade e eqüidade. Brasília: Instituto Nacional de Estudos e Pesquisas Educacionais, 1999.

CANIVEZ, Patrice. Educar o cidadão? Trad.: Estela dos Santos Abreu, Cláudio Santoro. Campinas, SP: Papirus, 1991.

CONSTANTINO, Luciana. "Ensino fundamental terá prova mirim". Folha de S.Paulo, 23/03/2005. C-1, p. 6.

ENGUITA, Mariano Fernández. "O discurso da qualidade e a qualidade do discurso". In: Neoliberalismo, qualidade total e educação. Petrópolis: Vozes, 2001.

FREITAS, Luiz Carlos de. Avaliação: construindo o campo e a crítica. Florianópolis: Insular, 2002.

GATTI, Bernardete A. "Avaliação educacional no Brasil: pontuando uma história de ações”. In: EcoS Rev. Cient. Uninove, São Paulo, v. 4, n. 1, 2002.

"Precisamos de política educacional efetiva antes de avaliar". Depoimento prestado no debate: Avaliação em educação: o que a escola pode fazer para melhorar seus resultados? In: Cadernos Cenpec, n. 3, São Paulo: Cenpec, 2007.

GENTILI, Pablo A. 'O discurso da 'qualidade' como nova retórica conservadora no campo educacional". In: Neoliberalismo, qualidade total e educação. Petrópolis: Vozes, 2001.

GÓIS, Antonio. "Exame mostra queda de nota na 4a série". Folha de S.Paulo, 6/12/2002, C-1, p. 14. 
GUIMARÃES, J. R. S.; JANNUZZI, P. M. "IDH, indicadores sintéticos e suas aplicações em políticas públicas”. In: Revista Brasileira de Estudos Urbanos e Regionais, v. 7, n. 1, 2005.

HADDAD, Fernando. O plano de desenvolvimento da educação: razões, princípios e programas. Brasília: Instituto Nacional de Estudos e Pesquisas Educacionais Anísio Teixeira, 2008.

HANSON, R. S. "Observação e interpretação". In: Morgenbesser, S. (org.) Filosofia da ciência. São Paulo: Cultrix, 1975.

HIRST, P. H.; PETERS, R. S. A lógica da educação. Trad.: Edmund Jorge. Rio de Janeiro: Zahar, 1972.

HIRST, P. H. "What is a Teaching?" In: PETERS, R. S. (org.) The Philosophy of Education. Oxford University Press, 1973.

KLEIN, Rubem. "Por uma educação de qualidade. avaliação e políticas públicas em educação”. In: Ensaio, v. 11, n. 38, pp. 115-120, jan/mar.2003.

LEALE, Francisco. Qualidade de ensino caiu entre 1995 e 2001. O Globo, Rio de Janeiro, 6.12.2002, p.18.

LEFORT, Claude. Desafios da escrita política. São Paulo: Discurso Editorial, 1999.

MATRIZES curriculares de referência para o Saeb. Maria Inês Gomes de Sá Pestana et al. Brasília: Instituto Nacional de Estudos e Pesquisas Educacionais, 1999.

MELLO, Guiomar Namo de. Cidadania e competitividade: desafios educacionais do terceiro milênio. São Paulo: Cortez, 1998.

MENEZES, Naercio. "Para além das salas de aula". Depoimento prestado no debate Avaliação em educação: o que a escola pode fazer para melhorar seus resultados? In: Cadernos Cenpec, n. 3. São Paulo: Cenpec, 2007. 
OAKESHOTT, Michael. “Aprendizagem e ensino”. In: Peters, R. S. (org.) The Concept of Education. London: Routledge \& Keagen, 1968.

OLIVEIRA, Romualdo; ARAÚJO, Gilda Cardozo. "Qualidade de ensino: uma nova dimensão da luta pelo direito à educação". In: Revista Brasileira de Educação, jan/fev/mar/abr.2005, n. 28.

“Reformas educativas no Brasil na década de 90”. In: CATANI, Afrânio; OLIVEIRA, Romualdo (orgs.) Reformas educacionais em Portugal e no Brasil. Belo Horizonte: Autêntica, 2000.

PASSMORE, John. The Phylosophy of Teaching. London: Duckworth, 1984.

PETERS, R. S. "Educação como iniciação”. In: Archambault, R. D. (org.) Educação e análise filosófica. São Paulo: Saraiva, 1979.

PNUD/UNESCO/UNICEF/BANCO MUNDIAL. "Declaração sobre educação para todos". Plano de ação para satisfazer as necessidades básicas de aprendizagem. Jomtien: 1990 (versão portuguesa). Brasília: Unicef, 1991.

PORTO, R. "A construção da qualidade na escola: uma experiência”. In: Revista Brasileira de Administração da Educação. Associação Nacional dos Profissionais de Administração da Educação, v. 12, n. 1 (jan/jun.1996), Brasilia, DF.

POSTMAN, Neil. O fim da educação: redefinindo o valor da escola. Rio de Janeiro: Graphia, 2002.

RISOPATRON, Verônica Edwards. El conecpto de calidad de la educacion. Santiago, Chile: Unesco/Orealc, 1991.

SCHEFFLER, Israel. A linguagem da educação. São Paulo: Saraiva, 1974. 
SILVA, Rose Neubauer. "A qualidade do ensino e a autonomia da escola". In: BORGES, A. S. (coord.) A autonomia e a qualidade do ensino na escola pública. São Paulo: FDE. Diretoria Técnica, 1993. (Série Idéias, n. 16.)

SILVA, Franklin Leopoldo. "O mundo vazio: sobre a ausência da política no contexto contemporâneo". In: SILVA, Doris Accioly; MARRACH, Sonia (orgs.) Mauricio Tratenberg: uma vida para as ciências humanas. São Paulo: Editora Unesp, 2001.

SILVA, Vandré G. Projeto pedagógico na escola pública: elementos para sua compreensão. Faculdade de Educação, USP, 2001. Dissertação de mestrado.

SILVA, Vandré G.; BAUER, Adriana. "Saeb e qualidade de ensino: algumas questões". In: Estudos em Avaliação Educacional, v. 16, n. 31, jan/jun.2005.

SOARES, Maria Victoria Benevides. "Educação para a democracia”. In: Lua Nova - Revista de Cultura e Política, 1996, n. 38.

SOUZA, Sandra Zákia L. "Possíveis impactos das políticas de avaliação no currículo escolar". In: Cadernos de Pesquisa, n. 119, jul/2003.

UNESCO - United Nations Educational, Scientific and Cultural Organizantion (1998). Primer studio internacional comparartivo sobre language, matemática y fatores associados em tercero e cuarto grado. Santiago, Chile: Unesco/ Laboratório Latinoamericano de Evaluación de la Calidad de la Educación.

UNICEF. Defining Quality. A Paper Presented by Unicef at the International Working Group on Education Meeting. Florença, Itália: jun/2000.

VIANNA, Heraldo M. Avaliação educacional: teoria, planejamento, modelos. São Paulo: Ibrasa, 2000.

Avaliações nacionais em larga escola: análises e propostas. São Paulo: DPE, 2003. (textos FCC, 23). 
WAGNER, Eugênia Sales. Hannah Arendt \& Karl Marx: o mundo do trabalho. São Paulo: Ateliê Editorial, 2002.

WEBER, Demétrio. "Escolas do Rio são destaque na Prova Brasil". O Globo, Rio de Janeiro, 01/07/2006, p. 13.

WINCH, Christopher; GINGELL, John. Key Concepts in the Philosophy of Education. New York: Routledge, 1999. 